UNIVERSIDADE SÃO PAULO

ESCOLA DE COMUNICAÇÕES E ARTES

DEPARTAMENTO DE MÚSICA

\begin{abstract}
A OBRA CORAL DE GILBERTO MENDES E A POESIA CONCRETA DO GRUPO NOIGANDRES: UMA ANÁLISE MULTIMIDIÁTICA
\end{abstract}

Rafael Alexandre da Silva 
RAFAEL ALEXANDRE DA SILVA

\title{
A OBRA CORAL DE GILBERTO MENDES E A POESIA CONCRETA DO GRUPO NOIGANDRES: UMA ANÁLISE MULTIMIDIÁTICA
}

\author{
Dissertação apresentada ao \\ Departamento de Música da Escola \\ de Comunicações e Artes da \\ Universidade de São Paulo, como \\ exigência para obtenção do título de \\ Mestre em Artes. \\ Linha de Pesquisa: Processos de \\ Criação Musical \\ Orientador: \\ Prof. Dra. Silvia Maria Pires \\ Cabrera Berg
}


Autorizo a reprodução e divulgação total ou parcial deste trabalho, por qualquer meio convencional ou eletrônico, para fins de estudo e pesquisa, desde que citada a fonte.

Catalogação na Publicação

Serviço de Biblioteca e Documentação

Escola de Comunicações e Artes da Universidade de São Paulo

Dados fornecidos pelo(a) autor(a)

SILVA, RAFAEL ALEXANDRE DA

A OBRA CORAL DE GILBERTO MENDES E A POESIA CONCRETA DO

GRUPO NOIGANDRES: UMA ANÁLISE MULTIMIDIÁTICA / RAFAEL

ALEXANDRE DA SILVA. -- São Paulo: R. SILVA, 2014.

$110 \mathrm{p}$.

Dissertação (Mestrado) - Programa de Pós-Graduação em

Música - Escola de Comunicações e Artes / Universidade de

São Paulo.

Orientadora: SILVIA MARIA PIRES CABRERA BERG

Bibliografia

1. Música 2. Processos de Criação Musical 3. Gilberto

Mendes 4. Poesia Concreta 5. Análise Multimidiática I.

BERG, SILVIA MARIA PIRES CABRERA II. Título.

CDD 21.ed. - 780 
Nome: SILVA, Rafael Alexandre da

Título: A Obra Coral de Gilberto Mendes e a Poesia Concreta do grupo Noigandres: uma análise multimidiática

Dissertação apresentada ao Departamento de Música da Escola de Comunicações e Artes da Universidade de São Paulo, como exigência para obtenção do título de Mestre em Artes.

Aprovado em:

Banca Examinadora

Prof. Dr.

Instituição:

Julgamento:----------------------------------------------------Assinatura:-

Prof. Dr.

Instituição:

Julgamento:

Assinatura:-

Prof. Dr.

-Instituição:

Julgamento:

Assinatura: 


\section{AGRADECIMENTOS}

À Profa. Dra. Silvia Maria Pires Cabrera Berg pela orientação precisa e pela boa condução na concepção, desenvolvimento e conclusão deste trabalho.

Ao compositor Gilberto Mendes, à sua esposa Eliane, e ao maestro Roberto Martins, que gentilmente nos receberam em suas casas, em Santos-SP, concedendo-nos valiosos relatos de experiência que nos nortearam ao longo deste trabalho.

Ao Prof. Dr. Antônio Eduardo Santos, que nos recebeu em sua casa, na cidade de Guarujá-SP, onde pudemos permanecer para realizar nossas entrevistas com o compositor Gilberto Mendes e o maestro Roberto Martins, e que também nos concedeu valiosos relatos de experiência e envolvimento com o compositor Gilberto Mendes.

Ao Prof. Dr. Rubens Russomano Ricciardi, coordenador do Núcleo de Apoio à Pesquisa em Ciências da Performance (NAP-CIPEM) da Faculdade de Filosofia, Ciências e Letras de Ribeirão Preto da Universidade de São Paulo (FFCLRP-USP), à Profa. Ms. Gisele Laura Haddad e à pesquisadora e mestranda Maria Beatriz Ribeiro Prandi, que me auxiliaram no acesso aos fac-similes e manuscritos originais das obras que editamos e analisamos, tendo sido doados pelo próprio Gilberto Mendes, e que pertencem aos arquivos do Serviço de Edição e Difusão de Partituras do NAP-CIPEM.

Aos meus pais Adriana e Rudolf, ao meu pai José (in memoriam) e irmãos, que sempre me incentivaram e me apoiaram emocional e afetivamente na busca pela concretização de meus sonhos.

Aos amigos Fernando Emboaba de Camargo, Cristina Emboaba de Camargo e José Gustavo Julião de Camargo, minha segunda família, com quem pude contar não só emocionalmente, mas também musical e academicamente, me orientando tantas vezes na condução deste trabalho.

À minha namorada Ana Paula, que foi fundamental nos momentos de conclusão deste trabalho, dando-me ânimo e forças para prosseguir. 


\section{RESUMO}

A música de Gilberto Mendes tem influenciado muitos compositores dentro e fora da universidade, dada a projeção que sua obra adquiriu, sobretudo ao longo da segunda metade do século XX. Sendo Gilberto Mendes um compositor versátil, escreveu inúmeros gêneros musicais, para diversas formações instrumentais, tendo ainda trabalhado com novas formas e sonoridades inspiradas, sobretudo, pela segunda escola de Viena e escola de Damstadt. Ao atentarmo-nos para o volume da obra coral, deparamo-nos com uma quantidade expressiva de obras para essa formação. Logo, ao debruçarmo-nos sobre essa forma de música coral onde a integração de duas Artes Poesia e Música - que evidencia toda a sua capacidade musical e linguística inovadora, tivemos, pois, que buscar ferramentas de análise capazes de abordar a obra com profundidade, de modo que os diversos aspectos componentes das obras não fossem deixados de lado. Obviamente, também o contexto em que a obra musical fora produzida, as influências marcantes e evidentes e o depoimento do próprio compositor acerca de sua criação são fundamentais para a construção, permanência e perpetuação da própria obra. O livro de Nicholas Cook, “Analysing Musical Multimedia”, oferece ferramentas acerca da abordagem com a qual poderemos analisar a singularidade desta obra que é, em essência, multimidiática, pois traz em si a conjunção de diferentes formas de arte (no caso, duas: poesia e música), gerando inúmeras possibilidades linguísticas. A metodologia utilizada consistiu em fichar a bibliografia básica, entrevistar o compositor Gilberto Mendes e o regente Roberto Martins, que regeu, praticamente, toda a obra coral do compositor, buscar e analisar as obras, e escrever a dissertação, ou seja, os resultados desta pesquisa. Os critérios de seleção das obras incluem aquelas para coral a capella que tenham texto dos poetas que compõem o grupo Noigandres - Augusto e Haroldo de Campos, e Décio Pignatari, expoentes da Poesia Concreta no Brasil. Logo, esperamos contribuir para o delineamento do perfil de uma obra substanciosa, cuja influência estende-se sobre o meio artístico e musical até os dias de atuais, e explorar os aspectos da linguagem deste que, sem dúvida, é um compositor relevante no cenário musical brasileiro e mundial.

Palavras-chave: Gilberto Mendes, Música Coral, Poesia Concreta, Noigandres, Teoria Multimidiática 


\begin{abstract}
The music by Gilberto Mendes have influenced composer in and out of university because of the importance such works acquired through second half of $\mathrm{XX}^{\text {th }}$ century. As a versatile composer that Gilberto Mendes is, he wrote many musical genres for many musical formations, new sonorities and forms inspired by the Second School of Wien and the School of Damstadt. By looking after the volume of his choir works it's possible to see an expressive amount of music written by him for this formation. By looking at this form of choir music where the integration of two forms of Art - Poetry and Music - which highlights all its musical and linguistic innovative capabilities, we so had to look after analytic tools that could approach deeply the works so that the many component aspects of these works won't be left aside. Obviously the context in which the work was made, the remarkable and evident influences, and the composer's own account about his creations are also basic on constructing, remaining and perpetration of the very works. The book "Analyzing Musical Multimedia" by Nicholas Cook offers analytic tools which allows us to look after the singularities of these works which is essentially multimedia, because it combines different forms of artwork in one (in this case, two - music and poetry) generating many linguistic possibilities. The methodology adopted consists on reviewing Mendes' basic biographic writings, interviewing him and the conduct Roberto Martins which performed practically all of Gilberto's work for choir, retrieving and analyzing the works, and writing the thesis, which are the results of all this research. The work inclusion criteria was choosing those whose were a capella works and whose texts were written by the poets who were members of the group Noigandres - Augusto e Haroldo de Campos, e Décio Pignatari, which are the Brazilian exponents of Concrete Poetry. By this we hope to outline a rich choir work which influences the artistical sphere until nowadays, and to explore many aspects of the language of this composer that is relevant in both Brazilian and world scenario.
\end{abstract}

Keywords: Gilberto Mendes, Choir Music, Concrete Poetry, Noigandres, Multimedia Theory 


\section{LISTA DE TABELAS}

Tabela 1 - Total de trabalhos encontrados por base de dados e biblioteca.................. 30

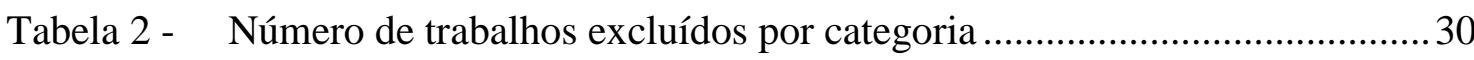

Tabela 3 - Trabalhos incluídos por base de dados e biblioteca .................................. 30

Tabela 4 - Número de trabalhos excluídos por base dados e biblioteca....................... 30

\section{LISTA DE FIGURAS}

Figura 1 - Gráfico dos trabalhos incluídos por ano de publicação.............................. 31

Figura 2 - Gráfico dos trabalhos incluídos por base de dados e biblioteca em

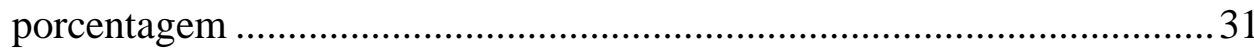

Figura 3 - As notas Lá e Si, que resumem as alturas definidas do início da peça .....55

Figura 4 - Acordes por empilhamento de quarta e quinta ........................................56

Figura 5 - Escalas pentatônicas que baseiam a obra ................................................. 61

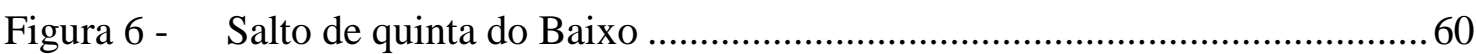

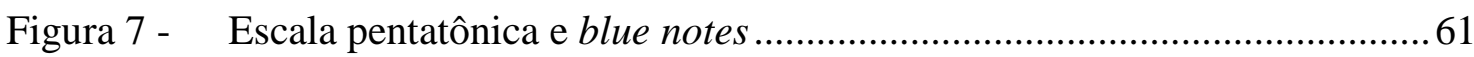

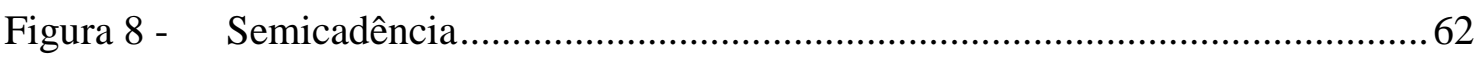

Figura 9 - Paralelismos e variação rítimica por tercinas .......................................... 63

Figura 10 - Escalas que baseiam a harmonia da peça ...............................................65

Figura 11 - Escala que baseia a peça, acrescida das blue notes ..................................65

Figura 12 - Acorde que sintetiza a harmonia através do empilhamento das notas da escala

Figura 13 - Trecho homofônico de "TV GRAMA I" ...................................................66

Figura 14 - Paralelismos característicos de orquestrações jazzísticas .........................67

Figura 15 - Linha de Baixo cromática ......................................................................69

Figura 16 - Acordes estáticos no final, acabando em "tv" .........................................69

Figura 17 - Cadência Frígia e Cadência Autêntica Perfeita dentro da progressão harmônica da frase inicial ....................................................................... 71

Figura 18 - Pedal na Subdominante Relativa (Fá maior) e alteração cromática.......... 73

Figura 19 - Cadência Deceptiva ou possível Elipse................................................... 73

Figura 20 - Modalismos na segunda progressão ..................................................... 74

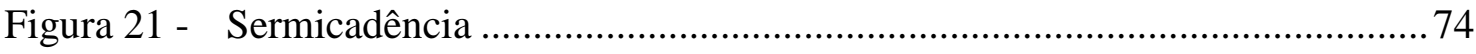


Figura 22 - Escala de Mi Frígio com o acréscimo da nota Dó sustenido .................... 75

Figura 23 - Cadência Autêntica Imperfeita que finaliza a peça .................................... 76

Figura 24 - Relações de terças e sextas - Compassos 31 a 33 ..................................... 82

Figura 25 - Trecho onde o coro realiza o teatro musical que remete ao disparo de

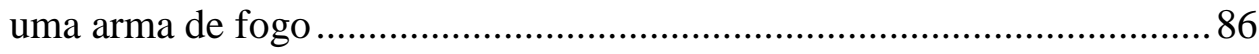




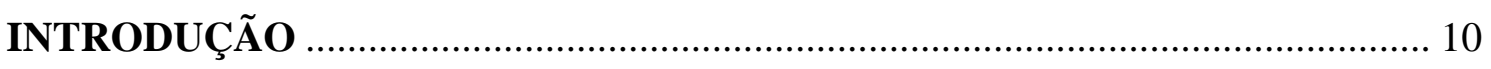

CAPÍTULO 1 - DOS ASPECTOS HISTÓRICOS ………..................................... 13

1.1 GILBERTO MENDES ....................................................................... 13

1.2 POESIA CONCRETA - O GRUPO NOIGANDRES ……………………..... 23

CAPÍTULO 2 - DAS TEORIAS ANALÍTICAS …………………………………...... 27

2.1 DAS TEORIAS DA POESIA CONCRETA …………………………….... 28

2.1.1 Da revisão bibliográfica ........................................................................... 28

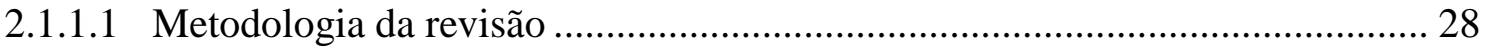

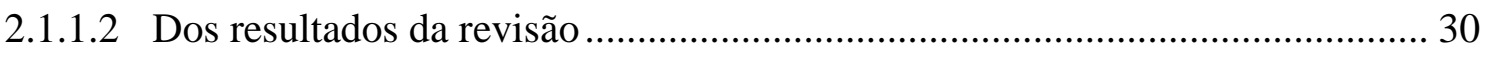

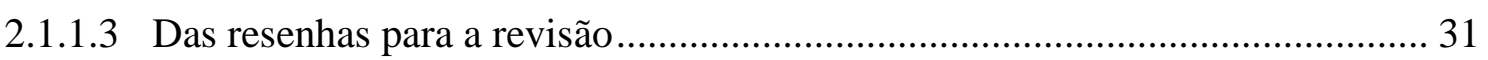

2.1.1.4 Das discussões e conclusões sobre a revisão.................................................... 40

2.1.2 Da teoria da Poesia Concreta, segundo Franchetti ............................................. 41

2.2 SOBRE A TEORIA ANALÍTICA MULTIMIDIÁTICA.................................. 43

2.2.1 Sobre o livro “Analysing Musical Multimedia"................................................. 44

CAPÍTULO 3 - DAS ANÁLISES ………………………………………………. 54

3.1 ANÁLISE DA OBRA “TEMPO TEMPO” .................................................... 54

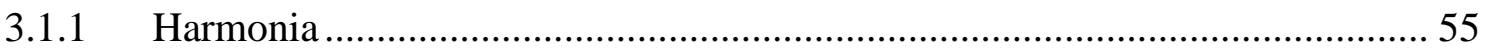

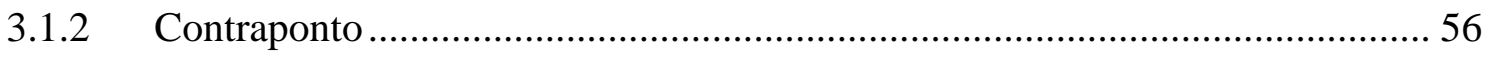

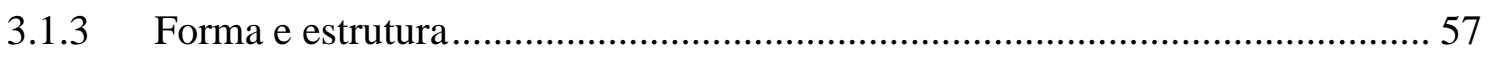

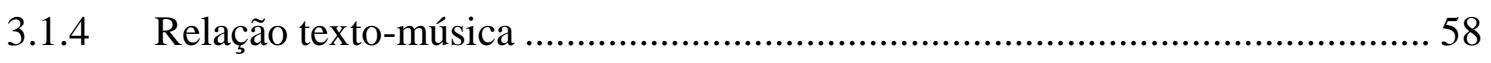

3.2 ANÁLISE DA OBRA "SOL DE MAIAKÓVSKI"......................................... 60

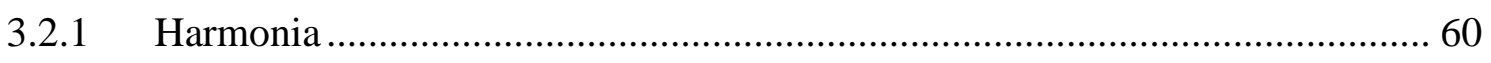

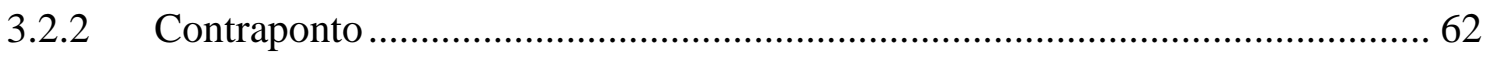

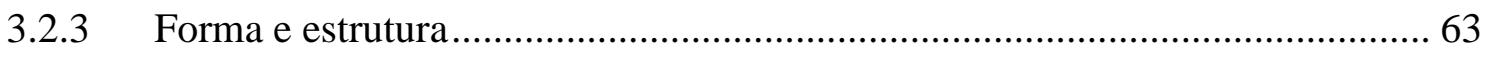

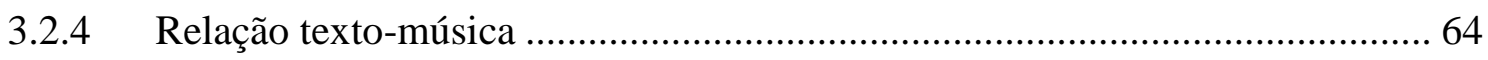


3.3 ANÁLISE DA OBRA “TV GRAMA I (TOMBEAU DE MALLARMÉ)” .... 64

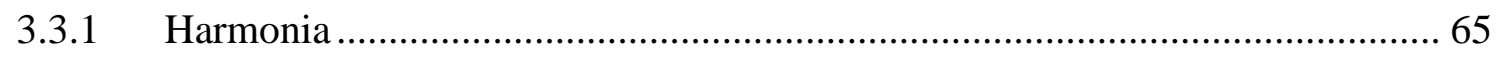

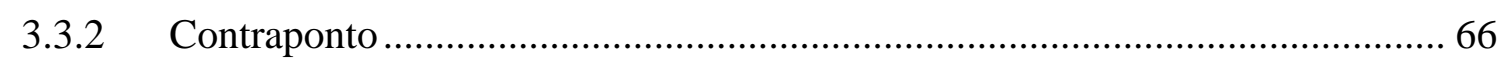

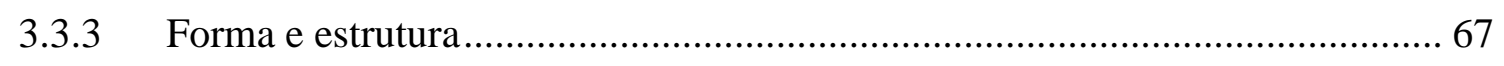

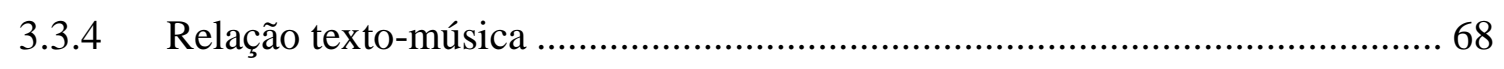

3.4 ANÁLISE DA OBRA “O ANJO ESQUERDO DA HISTÓRIA”.................... 70

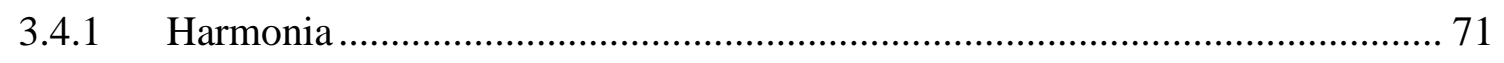

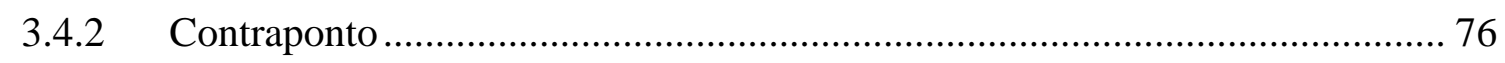

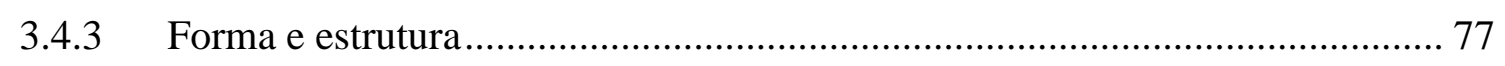

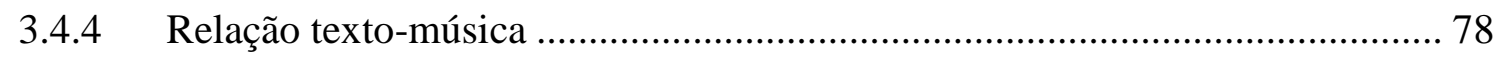

3.5 ANÁLISE DA OBRA “UMA VEZ, UMA VALA” ........................................... 80

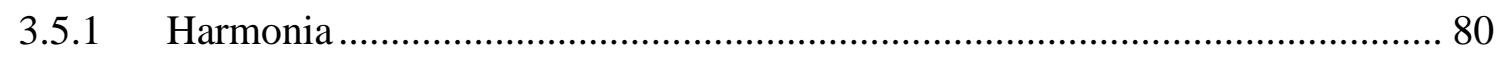

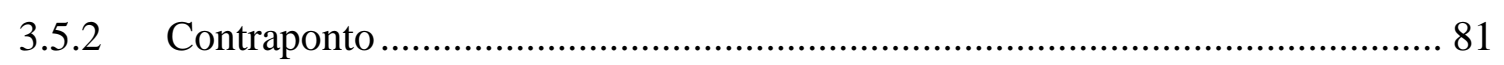

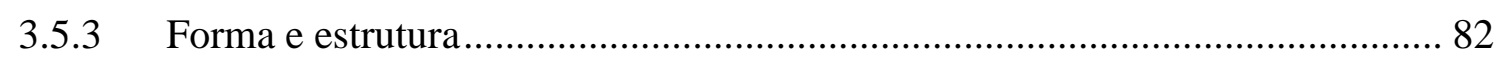

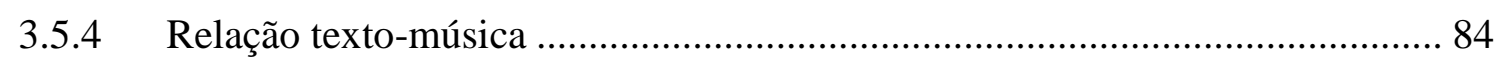

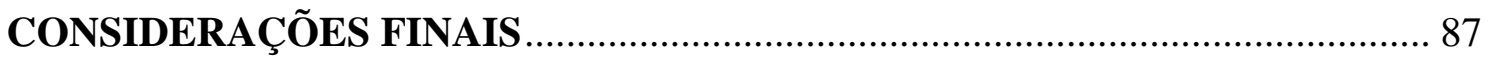

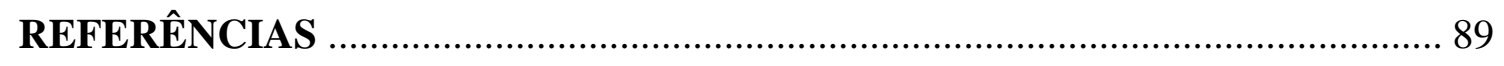

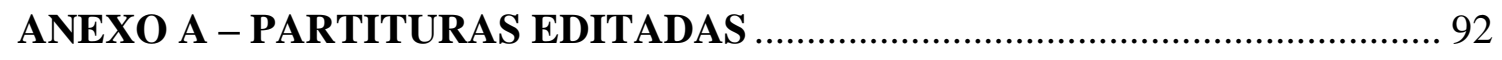

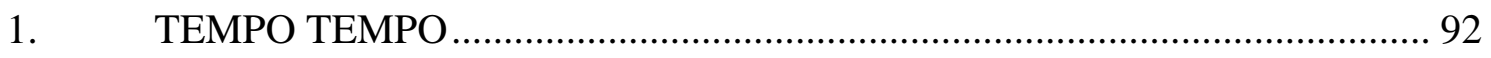

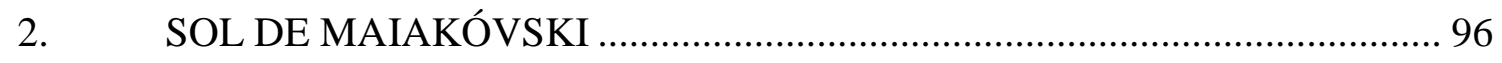

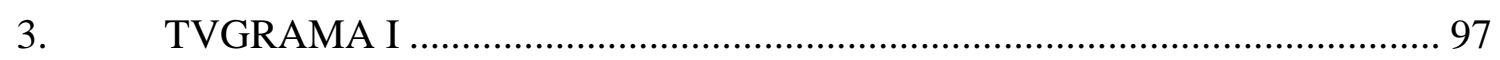

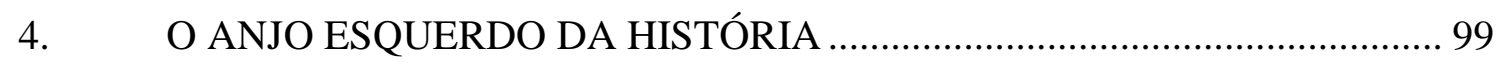

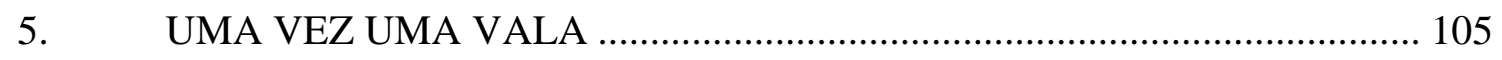




\title{
INTRODUÇÃO
}

A música de Gilberto Mendes tem influenciado muitos compositores dentro e fora da universidade, dada a projeção que sua obra adquiriu, sobretudo ao longo da segunda metade do século XX. Sendo Gilberto Mendes um compositor versátil, como ele mesmo afirma em seus livros autobiográficos, docente da Universidade de São Paulo, atuando no Brasil e no exterior, escreveu inúmeros gêneros musicais e para diversas formações instrumentais, tendo ainda trabalhado com novas formas e sonoridades inspiradas, sobretudo, pela segunda escola de Viena ${ }^{1}$ e escola de Damstadt ${ }^{2}$. Tais envolvimentos com a música de vanguarda culminou, juntamente com outros compositores seus contemporâneos, no Manifesto Música Nova (SOUZA, 2013).

O volume de sua obra, em termos de número de produção, pode ser observado nos apêndices de seu livro "Uma odisseia musical". Ao atentarmo-nos para o volume da obra coral, deparamo-nos com uma quantidade expressiva de obras para essa formação. Sendo assim, e segundo consta em sua biografia, dada a natureza singular da produção literária poética nacional, sobretudo dos poetas concretos, optamos por nos debruçar sobre aquela música cujo empenho do compositor foi o de entrelaçar a poesia e os sons de modo a consubstanciar uma música que fosse essencialmente brasileira e nova, conforme o compositor afirma no referido livro:

\begin{abstract}
Eles [os compositores europeus] nem tinham à sua disposição textos da qualidade daqueles que a poesia concreta nos oferecia. Era uma invenção nossa, original, portanto, não uma imitação do que se fazia na Europa, que é o que sempre dizem das obras de vanguarda terceiro-mundistas... (MENDES, Gilberto. apud CAMPOS, Haroldo de. In: idem. Uma odisseia musical. P. XI).
\end{abstract}

Logo, ao debruçarmo-nos sobre essa forma de música coral onde a integração de duas Artes - Poesia e Música - que evidencia toda a sua capacidade musical e linguística inovadoras, tivemos, pois, que buscar ferramentas de análise capazes de abordar a obra com profundidade, de modo que os diversos aspectos componentes das obras não fossem deixados de lado. Obviamente, também o contexto em que a obra

\footnotetext{
${ }^{1}$ Diz respeito ao grupo formado pelos compositores Arnold Schoenberg, Anton Webern e Alban Berg antes da Primeira Guerra Mundial, cujas obras se concentraram sobre o uso das técnicas atonais e dodecafônicas. Referência: <http://www.oxfordmusiconline.com/subscriber/>. Acessado em 11 de julho de 2013.

${ }^{2}$ A escola de Damstadt é marcada pelo serialismo integral, expandindo a técnica serial criada por Arnold Schoenberg (1874-1951), e pela música eletroacústica e experimental. Reunia compositores como Luigi Nono (1924-1990), Pierre Boulez (1927) e, mais recentemente, Iannis Xenakis (1922-2001).
} 
musical fora produzida, as influências marcantes e evidentes e o depoimento do próprio compositor acerca de sua criação são fundamentais para a construção, permanência e perpetuação da própria obra.

O livro de Nicholas Cook, "Analysing Musical Multimedia", oferece ferramentas acerca da abordagem com a qual poderemos analisar a singularidade desta obra que é, em essência, multimidiática, pois traz em si a conjunção de diferentes formas de arte (no caso, duas: poesia e música), gerando inúmeras possibilidades linguísticas. O texto de Vincent Persichetti "Twentieth Century Harmony - Creative Aspects and Practice" aborda as técnicas da música contemporânea e seus usos em diversas obras, com inúmeros excertos musicais, contribuindo, assim, para a análise das técnicas e processos composicionais musicais usadas por Mendes para a criação de sua obra coral. Do mesmo modo, contribuem o livro "A Música moderna", de Paul Griffiths, nos permitirá melhor compreender a formação da linguagem musical do século XX e do próprio Gilberto Mendes, e o livro sobre formas musicais de William Caplin (1999). Sobre os aspectos da poesia concreta, referenciamo-nos nos textos de "Teoria da Poesia Concreta", de autoria do grupo Noigandres (Augusto e Haroldo de Campos e Décio Pignatari), no livro "Alguns aspectos da teoria da poesia concreta", de Paulo Franchetti e nos artigos científicos de Elisa Gomes da Costa, Elsa Simões, Pedro Erber e Rachel Price, que nos permitirão a compreensão e análise dos textos das obras corais analisadas.

A metodologia utilizada consistiu em fichar a bibliografia básica, entrevistar o compositor Gilberto Mendes e o regente Roberto Martins ${ }^{3}$, que regeu, praticamente, toda a obra coral do compositor, buscar e analisar as obras, e escrever os resultados desta pesquisa nesta dissertação. Os critérios de seleção das obras incluem aquelas para coral a capella que tenham texto dos poetas que compõem o grupo Noigandres Augusto e Haroldo de Campos, e Décio Pignatari. As obras selecionadas são: "O Anjo Esquerdo da História", "TVGRAMA I", "Uma Vez Uma Vala”, “Tempo Tempo" e "Sol de Maiakóvski". As obras "Com Som Sem Som" e "Motet em Ré menor (Beba Coca-Cola)", com texto de Augusto de Campos e Décio Pignatari, respectivamente, entrariam em nossos critérios, mas por se tratarem de obras mais antigas do compositor e que já foram executadas e editadas, ao contrário das cinco citadas primeiramente,

\footnotetext{
${ }^{3} \mathrm{O}$ registro sonoro das entrevistas infelizmente se perdeu numa pane eletrônica dos equipamentos de gravação. Entretanto, contamos com uma declaração de próprio punho, tanto do compositor Gilberto Mendes, quanto do regente Roberto Martins, atestando que estivemos em Santos e realizamos a entrevista com cada um deles.
} 
optamos por não incluí-las a fim de promovermos aquelas obras do compositor que ainda se encontram manuscritas e que têm pouca circulação pública.

A estrutura dos capítulos segue uma linha de raciocínio que visa, no primeiro capítulo, expor a vida musical de Gilberto Mendes, o contexto histórico em que viveu, e as influências - segundo seus depoimentos e livros - que recebeu ao longo da vida e que tiveram mais relação com a criação de sua obra coral, e os aspectos históricos que cercam o grupo Noigandres e sua formação. Para tanto, o texto "Gilberto Mendes entre a vida e a arte", de Carla Delgado de Souza ${ }^{4}$, os referidos textos de Paulo Franchetti, além dos livros de autoria do próprio Gilberto Mendes, servirão de referência para a construção do texto.

No segundo capítulo, expomos as teorias analíticas literárias e multimidiáticas que nos permitiram uma abordagem técnica e processual mais ampla, de modo a contemplar analiticamente a obra na intersecção entre poesia e música.

No terceiro capítulo, fizemos a análise musical das obras sob a perspectiva dos processos composicionais utilizados, aplicando as teorias previamente estudadas e expostas, permeando os processos composicionais com análises do texto e contexto - a abordagem histórica e social - de modo a obtermos uma visão ampla sobre a obra, que alargue a compreensão da mesma sob múltiplos aspectos.

Finalmente, conforme afirmado anteriormente, nossa intenção é contribuir para o delineamento do perfil de uma obra substanciosa, cuja influência estende-se sobre o meio artístico e musical até os dias de atuais, e explorar os aspectos da linguagem deste que, sem dúvida, é um compositor relevante no cenário musical brasileiro e mundial (SOUZA, 2013).

\footnotetext{
${ }^{4}$ A autora assim define seu livro: "Este livro é uma etnografia da experiência social de Gilberto Mendes, procurando compreender, com base em uma abordagem biográfica, como o compositor enfrentou alguns dilemas estéticos e relacionou-se com instâncias políticas e de poder do campo musical desde os anos 1940, quando decidiu tornar-se músico até o momento de sua consagração como músico erudito no Brasil e no exterior." (SOUZA, 2013, p. 31).
} 


\section{CAPÍTULO 1 - DOS ASPECTOS HISTÓRICOS}

Longe de nos aprofundarmos em demasia nos aspectos históricos, sobretudo porque o objetivo da dissertação é a compreensão dos processos composicionais das obras corais a capella de Gilberto Mendes que utilizam texto do grupo Noigandres, buscamos delinear o contexto no qual viveu o compositor, bem como os aspectos da formação do grupo dos poetas concretos, de modo que tais informações possam enriquecer e contribuir para a análise posterior das obras, pois estudar a vida do artista serve para "iluminar as obras através da biografia, já por sua vez iluminada pelas próprias obras" (PAREYSON, 1997, p. 96).

Inicialmente, baseando-nos nos livros do compositor e no trabalho de SOUZA (2013), trazemos aqueles aspectos que pensamos ser relevantes em relação à proposta da dissertação e apontamos algumas questões para reflexão. A seguir, detemo-nos sobre os poetas do grupo Noigandres, com o apoio de FRANCHETTI (2012), de modo que a conjunção entre as duas exposições venham a contribuir, a posteriori, com as considerações do Capítulo 3, que são as análises das obras propriamente.

\subsection{GILBERTO MENDES}

O santista Gilberto Mendes nasce em 13 de outubro de 1922 em Santos, litoral de São Paulo, onde vive até hoje. Recebeu educação formal em escola pública. Seus primeiros contatos com a música erudita foram através de discos de vinil que o tio possuía. Gilberto Mendes diz que sua paixão pelo cinema se deve à música, que serviu como atrativo para a arte cinematográfica devido ao fato de as exibições serem ainda do cinema mudo, portanto, acompanhadas de música orquestral, com trechos de grandes obras. E quando o filme ganhou voz, ele já havia se tornado um assíduo fã dessa modalidade de arte (MENDES, 1994). O cinema lhe impressionou tanto que, em seu primeiro livro, ele escreveu que Hollywood e seu potencial cultural é o "verdadeiro Olimpo surrealista de nosso tempo, com seus deuses e deusas fascinantes." (MENDES, 1994, p. 11). Iniciou seus estudos formais em música aos 18 anos, ingressando no Conservatório de Santos. 
Gilberto Mendes pensou em seguir a carreira do pai e ser médico quando mais jovem. Chegou a entrar para a Faculdade de Direito do Largo do São Francisco em São Paulo, mudando de ideia e pensando em ser advogado, mas como gostava muito de música e recebeu o incentivo do cunhado Miroel Silveira, o compositor se decidiu por dedicar-se à Arte, pois, segundo afirma, ele havia sido "tocado já ao nascer pela mais alta e espiritual forma do conhecimento humano, e de Deus, que é a arte, em suas manifestações mais superiores." (ibidem, p. 9). No entanto, como começara tardiamente os estudos musicais, tendo que prover seu sustento, optou por prestar concurso público, com o incentivo da mãe, para ser funcionário da Caixa Econômica Federal, onde fez carreira e se aposentou. Mendes diz que "ama a arte" (ibidem, p. 38) e que se sente orgulhoso por não ter sido um compositor profissional, ou seja, que tirava o sustento do seu fazer musical, mas, sim, que se sente muito feliz por ter sido um amador, que trabalhava em um banco e que, embora todo esse trabalho além de seu fazer musical lhe tomasse tempo, ele não tem amargura ou arrependimento, pelo contrário, a arte, a poética musical sempre lhe foram mais importantes que a fama que o seu trabalho poderia alcançar (MENDES, 1994). Segundo SOUZA (2013), a aversão de Mendes pelo meio acadêmico e por ser reconhecido como um compositor profissional foi fundamental na construção de sua linguagem composicional na medida em que a liberdade criativa que possuía por não estar ligado a qualquer instituição lhe possibilitava compor sem amarras ${ }^{5}$.

Gilberto Mendes afirma ter sido sensibilizado, alguém tocado pelos bons costumes e boas maneiras, pela grande arte, desde menino, no entanto, ele não faz juízos de valor sobre isto, dizendo que isto é o ideal a qualquer um em fase de crescimento (MENDES, 1994).

Em sua ânsia por aprender, Mendes chegou a procurar o compositor Camargo Guarnieri para ter aulas, mas ele o indicou para ter aulas com um aluno. Sendo assim, Gilberto optou, então, por não fazer aulas com esse aluno, pois sua vontade era estudar com o famoso compositor. Apesar de ter buscado instrução formal, o compositor afirma: "Nasci pra ser autodidata." (ibidem, p. 34).

Embora sua primeira empreitada em estudar com Guarnieri não tenha dado certo, Mendes fora acolhido pelo compositor Olivier Toni, que lhe apresentou o alemão

\footnotetext{
${ }^{5}$ Assim, até mesmo a polivalência estética de Gilberto Mendes precisa ser compreendida em contexto, já que, mesmo pertencendo a grupos que se definiam por defesas apaixonadas a certos ideais, ele nunca teve convicções radicais em relação a nenhum posicionamento político ou estético (SOUZA, 2013, p. 35).
} 
radicado no Brasil Hans-Joachim Koeullreuter, responsável pela introdução da vanguarda em terras brasileiras, sobretudo da Segunda Escola de Viena (SOUZA, 2013). Ao contrário do que se afirma a respeito da presença da música popular em sua obra ser um possível reflexo de sua vivência musical, sua iniciação se deu inteiramente no universo da música de concerto, e acrescenta que isso seria uma "Coisa inconcebível, em nossos dias.” (MENDES, 1994, p. 7). Sobre os compositores populares, Mendes acrescenta: "Na deles [os compositores de seu tempo], sentimos claramente as raízes brasileiras. Na minha, eu sinto claramente as raízes europeias, o Classicismo, o Romantismo." (1994, p. 8).

Em muitos momentos de seu primeiro livro - Uma Odisseia musical - Mendes transparece certa melancolia que, segundo ele, podia ser percebida em sua música, conforme lhe haviam relatado outros músicos e amigos:

O maestro Klaus-Dieter Wolff, grande intérprete de minhas obras corais, dizia que minha música, quando não estava às voltas com novas formas de organização sonora, microtonalismo e outras pesquisas, quando era simplesmente tonal, de comunicação fácil, tinha sempre um caráter melancólico. São as blue notes, que eu sempre gostei de colocar em minhas melodias e harmonias, as cromatizações pelos bemóis (ibidem, p. 10).

É interessante notar que, a certa altura de seu texto, MENDES assume seu contato com a música popular, mas não a música popular brasileira - o chorinho, o samba, o maxixe, etc. - e, sim, a música popular estadunidense das big bands e o jazz. Sobre a música brasileira de sua época, o compositor coloca:

fizeram uma serenata bem ao gosto da época, com músicas seresteiras, genuinamente brasileiras. Devo confessar que achei bastante chatas aquelas músicas, não me comoviam, eram pobres de interesse para mim. Preferia incomparavelmente a música norte-americana. O que podia fazer? Estava selado o meu destino (ibidem, p. 11).

E mais:

aquela coisa pobre da música popular em si, que me incomodava; sua limitação, seu mundo pequeno. Estou me referindo à música popular urbana, a folclórica é outra conversa, tem sua dignidade, é uma música honrada (ibidem, p. 13).

Mendes diz que seu gosto sempre foi o mesmo, que não mudou, apenas se aperfeiçoou, e que desde sempre ele se pensou como sendo adulto, devido ao próprio meio em que viveu, sempre entre pessoas mais velhas, e que, desde então, internalizou em si próprio o conhecimento, o saber como algo demasiado precioso e vital para reger as boas relações entre os homens (MENDES, 1994). 
Apesar da maturidade da tenra idade, contatada por Gilberto sobre si mesmo, o compositor afirma não ter sido precoce e ter aproveitado muito bem a própria infância. Ele ainda afirma que a arte esteve sempre dentro dele, e que ele manifestava isto através de brincadeiras artísticas, como a confecção de livros, a escritura de estórias e os desenhos no estilo dos cartazes de cinema da época (MENDES, 1994).

Da música popular urbana, Mendes exalta, sobretudo, aquela de origem estadunidense que tem relação com o cinema, em suas orquestrações e harmonias aproximadas à música do Romantismo europeu. Ele afirma que essa música chega a ser tão expressiva quanto a dos românticos, muito embora se trate de "música barata" (ibidem, p. 14) e feita para a massa:

Era essa estreita ligação com a música erudita que me interessou profundamente nesse Lied do século XX, que eu entendia como o fruto de uma extensão do clássico-romantismo, impregnada de uma nova atmosfera, urbana, mais moderna e mais popular, naquilo que o popular tem de mais digno (ibidem, p. 15).

Em seu primeiro livro, Gilberto Mendes cita exemplos musicais de compositores do Romantismo europeu para trazer à tona seus mecanismos expressivos e compará-los e expor sua presença nos cancionistas urbanos estadunidenses do início do século XX (MENDES, 1994). Mas o compositor afirma estar consciente de que a música popular, para ele, não pode alcançar o status de música erudita: "São as qualidades, as propriedades da música erudita, que a música popular não pode ter, dado o caráter de sua comunicação persuasiva. Se as tivesse, não seria popular.” (ibidem, p. 21).

Veementemente, Gilberto afirma que a música erudita deve se separar da popular, que ela deve preservar seu caráter impopular, que ela deve ser para poucos, que a fama é para a indústria cultural, não para os músicos eruditos, e que ela assim deve se preservar, pois “A grande Arte é por natureza impopular” (ibidem, p. 61).

Por que tentar 'popularizar', 'vulgarizar' uma música que por sua própria natureza é impopular, invulgar? A preparação para as coisas elevadas do espírito é fundamental. Um ritual a ser exigido. A grande Música deve ser ouvida como numa oriental cerimônia do chá. No seu devido lugar (ibidem, p. 61).

Mendes afirma que a indústria cultural tem por ideal massificar, vulgarizar, e que os compositores, portanto, devem se afastar dela, pois a grande Música é arte elevada, para uns poucos, não é para a maioria. Gilberto reforça essas ideias de separação entre a grande Arte e a Indústria da Cultura: que a primeira não pode nem deve ser para todos, como se a maioria das pessoas não tivesse, devido à falta de contato 
com essa alta cultura, meios para compreender tal Arte, como se ela só fosse acessível aos pares daqueles que a fizeram (MENDES, 1994). Segundo SOUZA (2013), a postura de exclusividade que Gilberto tem em relação à música erudita é um processo de construção da sua própria identidade do enquanto compositor, e não uma exclusão em relação aos, por exemplos, leigos ao assunto ${ }^{6}$.

Partindo para sua formação como compositor, Gilberto estudou primeiramente com o italiano Savino de Benedictis que, segundo ele, desviava-o de sua "natureza musical atonal" (MENDES, 1994, p. 43), e que, por isso, ele teria resolvido por estudar composição de maneira autodidata:

Eu já ansiava, no íntimo, pela não-peridiocidade, pelo não-discursivo e a nãorepetição, características da neue Musik que iria praticar, faltavama inda muitos anos. Eu intuía as coisas mas não tinha o conhecimento técnico e teórico necessários. E essa condição iria caracterizar minha primeira fase como compositor (ibidem, pp. 45, 46).

Através de uma série de estudos, o compositor afirma ter construído a bagagem teórica com a qual iniciou a primeira fase de sua obra musical, inventando, assim, seu estilo (MENDES, 1994). A incompletude das informações teóricas acerca de composição de que ele dispunha foram fundamentais para seu processo criativo, haja vista que uma vez que ele não conhecia as músicas (entenda-se fontes musicais, partitura) e os processos que ele estudava integralmente, Mendes tinha que inventar e supor o que lhe estava oculto (MENDES, 1994).

Sendo assim, Gilberto caracteriza essa primeira fase de sua obra como "tonal com clima poli/atonal" (ibidem, p. 53). A existência de uma dialética nele mesmo entre a música tonal, vinda de seu gosto pela música popular estadunidense dos anos 20 do século passado, e a música atonal, resultou, para ele, que, embora sua música tivesse um apelo consonante, não poderia se dizer tonal, uma vez que os acordes, a harmonia que ele utilizava, não era hierarquizada conforme as regras da harmonia tonal. "O próprio tonal deveria parecer atonal, no encadeamento não funcional dos acordes." (ibidem, p. 44). Mas isso não se deve aos seus estudos autodidatas, ou seja, por não conhecer formalmente a harmonia, pois havia estudado harmonia ainda na juventude. Essa marca não tonal era muito mais uma preferência, "construindo um gosto e inconscientemente

\footnotetext{
6 "É essa identidade - ser compositor de um determinado tipo de música - que confere o direito e o merecimento de ouvir os grandes, o que para Gilberto Mendes é fundamental. Para isso, foi necessário que nosso protagonista se inserisse no campo musical e, mais ainda, que nele trabalhasse de forma a ser considerado por esse próprio meio alguém que fazia parte daquele contexto específico" (SOUZA, 2013, p. 242).
} 
uma linguagem musical, para o futuro, por meio dessa observação, (...). Sempre fez parte de minha natureza essa busca pelo novo.” (ibidem, p. 21).

Mendes afirma que, a partir do Manifesto Zhdanov" e da "Carta Aberta"8 do compositor Camargo Guarnieri, manifestos que evocavam a necessidade da busca de uma identidade nacional em detrimento do cosmopolitismo, marca predominante de sua obra até então, ele passou a se ocupar do folclore nacional, não com harmonizações e arranjos de melodias, mas incorporando o espírito nelas contido e recriando a aura de que elas se revestiam. Para ele, essa experiência com o folclore resultou em uma música muito parecida com o que seria a bossa-nova anos mais tarde:

A natureza comunicativa e o leve toque quase popular que minha música sempre teve, agora reforçado pelo estudo de nosso folclore, mais o uso de uma harmonização culta e refinada que eu assimilaria de Debussy e Bartók, permitiriam que eu me antecipasse, a nível erudito e mais avançado, na criação de certos complexos melódico-harmônicos semi-eruditos da bossa nova (MENDES, 1994, p. 55).

Apesar de seu posicionamento antinacionalista, Mendes reconhece em sua obra um caráter brasileiro, inclusive grifado por críticos e outros compositores, caráter este que ele atribui ao seu contato com a música popular (MENDES, 1994).

Da sua viagem à Europa em 1959, Gilberto afirma ter travado contato com a obra de Stockhausen, e que através dela ele reconheceu e conheceu Anton Webern, e que tal experiência foi fundamental para os novos rumos que sua arte musical tomaria a partir de então. E foi preciso, para tanto, retornar ao autoditatismo, ao estudo das partituras daqueles compositores, apreendendo por si mesmo os rumos da neue Musik (MENDES, 1994). Após voltar da Alemanha, Mendes acredita ter assimilado tudo aquilo que ele precisava acerca da vanguarda, e que o principal ponto que ele teria aprendido é que ele deveria criar sua própria linguagem, distanciando-se daquilo que era feito na Europa, "Criar signos novos." (ibidem, 1994).

A partir desse exato momento, o contato também com a literatura de vanguarda, e entenda-se aí a poesia concreta, uma Arte, segundo o Gilberto, brasileira por excelência, é que suas obras corais sobre textos concretistas, com uma linguagem

\footnotetext{
${ }^{7}$ Escrito pelo político soviético Andrei Zhdanov, versava sobre as definições de produção artística e cultural do regime comunista da União Soviética, e como tal produção deveria ser engajada com os ideais nacionais soviéticos.

${ }^{8}$ Sobre a "Carta Aberta", SOUZA (2013) escreve: "o compositor nacionalista [Camargo Guarnieri] escreveu sua primeira Carta Aberta, endereçada ao compositor alemão radicado no Brasil [Koellreutter] e publicada na Revista Resenha Musical (ano IV, no 37), alertando-o de que se continuasse compondo de acordo com a estética preconizada pela segunda escola de Viena, ele seria odiado pelo público, que estaria em busca do belo na música, algo inatingível pela linguagem atonal" (SOUZA, 2013, p. 77). As correspondências abertas ao público entre os dois compositores começaram em 1941 e duraram até 1951.
} 
musical ligada à Neue Musik, surgem. Para Mendes e, também, Haroldo de CAMPOS (2006; In: MENDES, 1994) existe uma analogia entre a poesia concreta e o dodecafonismo, onde ambos buscam na simplicidade da técnica a saída para promover sua mensagem e torná-la acessível a qualquer um, leigo ou não. "O dodecafonismo e o concretismo trouxeram uma grande unidade à música e à poesia de nosso tempo" (MENDES, 1994, p. 76).

Mendes considera que sua música coral é um avanço em relação ao que se fazia na Europa, e algo exclusivamente novo, haja vista que ele adiantou muitas das questões técnicas, sobretudo de pensar a sonoridade do coro no contexto da música concreta, que os compositores só usariam por lá muito tempo depois. “(...); eles nem tinham à sua disposição textos da qualidade daqueles que a poesia concreta nos oferecia. Era uma invenção nossa, (...), não uma imitação do que se fazia na Europa, que é o que sempre dizem das obras de vanguarda terceiro-mundistas, (...)” (ibidem, p. 84). O caráter da música que Mendes fazia, segundo ele mesmo, era tecnicista, fruto de seu próprio tempo, mas não um tecnicismo redutivo, e, sim, um tecnicismo que busca uma natureza maquinal e minimalista, onde a música se comporia sozinha a partir de instruções, como uma máquina de criar música, não de reproduzir [vide obra Brilium] (MENDES, 1994).

A esta altura, temos o Manifesto Música Nova ${ }^{9}$, assinado pelos compositores Willy Corrêa de Oliveira, Rogério Duprat, Damiano Cozzela e Gilberto Mendes, entre outros músicos, que revolucionou a linguagem musical a seu tempo, baseado nas teorias e técnicas mais recentes, tanto musicais quanto extra-musicais, revolução essa que ele mesmo compara a que Villa-Lobos construiu, sozinho, no início do século $\mathrm{XX}$, no entanto, de maneira mais intuitiva (MENDES, 1994). O grupo de compositores signatários do Manifesto Música Nova foi pioneiro no teatro musical (MENDES, 1994). Ele ainda afirma que sua música nesse gênero tem inspiração em outras artes, como a literatura, a arquitetura, as artes plásticas, o cinema, que na música em si.

Como epítome dessa fase de sua linguagem, Mendes cita sua peça Santos football music, que integra, segundo o autor, quase todas as características e processos composicionais da vanguarda da década de 1950 em diante, "o som concreto (...), o som orquestral atonal, sem melodias $(\ldots),(\ldots)$, a participação do público na obra, (...), o teatro musical, (...), e o novo grafismo" (ibidem, p. 126).

\footnotetext{
${ }^{9}$ Manifesto escrito por Rogério Duprat, assinado por, entre outros músicos e compositores, Gilberto Mendes, e que trazia o ideário estético e até político da vanguarda musical em 1963, data de sua publicação na revista Invenção (SOUZA, 2013).
} 
Gilberto diz que sua música, na década de 1960, passa a ser confundida com música popular. No entanto, "Uma vez erudito, sempre erudito" (Ibidem, p. 153), ou seja, sua música trazia resquícios da música popular de sua época, da bossa-nova, do iêiê-iê, mas era produzida academicamente (MENDES, 1994). O que reafirma sua postura de oposição em relação à indústria da cultura. Entendemos que o envolvimento de sua música com a música de mercado pode ser visto como uma analogia ao movimento da poesia concreta em relação à música de consumo.

João Cabral de Melo Neto, na conferência "Poesia e Composição", em 1952, proferida na Biblioteca Municipal de São Paulo (cf. FRANCHETTI, 2012), convoca os poetas a se reconciliarem com o público através da aproximação da poesia por temas cotidianos, que dialoguem com as novas demandas apresentadas pela cultura de massa. No entanto, a ideia trazida pelos poetas concretos, num primeiro momento, se enquadre na proposta de negar a facilidade do acesso à obra, tanto ao público quanto ao próprio poeta, que deveria debruçar-se arduamente sobre sua produção, torna-se, posteriormente, o oposto, onde a obra deve apropria-se dos meios de comunicação de massa, a fim de que o púbico mais leigo e menos letrado também possa ter acesso a ela (FRANCHETTI, 2012). Ora, também na obra coral de Gilberto Mendes, temos essa aproximação com a indústria da cultura e os meios de comunicação de massa, conforme ele afirma diversas vezes em seus livros quando analisa obras como Asthmatour (ibidem, p. 92-93), que tem um apelo propagandístico, e Vila Socó Meu Amor, como música de campanha, de propaganda, jingle (ibidem, p. 156), além do consagrado Motet em Ré menor (Beba Coca-Cola), concebido como um "antijingle" (SOUZA, 2013, p. 149). Percebe-se, assim, uma analogia das posturas estéticas do compositor para com aquelas posturas defendidas pelo grupo Noigandres. Seria, então, a música de Mendes concreta, na acepção literária da palavra?

Sobre a relação de Gilberto Mendes com a indústria da cultura, SOUZA (2013) propõe:

A dicotomia entre arte e mercado continua sendo vista como um problema para tanto para Gilberto Mendes como para Willy Corrêa de Oliveira, mesmo após a desvinculação de ambos da estética de vanguarda, processo que se iniciou em fins dos anos 1970. Embora haja uma reelaboração significativa no que se refere ao universo popular - que passou a ser visto não apenas como representativo da indústria cultural para ambos os compositores -, a música com fins mercadológicos continua sendo malvista por ambos (ibidem, p. 248). 
Trata-se, logo, de um trabalho sobre o que a música da indústria traz com o intuito de se apropriar dessa linguagem para criar algo novo e se aproximar com o público.

É evidente que a aproximação da poesia concreta com a indústria da cultura não visa um empobrecimento da literatura, e tampouco se pode afirmar o mesmo sobre a música de Gilberto Mendes, sobretudo por sua postura schoenbergiana em relação à obra de arte, mas, conforme afirma FRANCHETTI (2012), a busca dos poetas concretos faz com que a poesia concreta, com sua origem erudita, “(...) seja simultaneamente a poesia mais adequada à comunicação imediata com o leitor leigo e despreparado culturalmente." (FRANCHETTI, 2012, p. 187). Sobre a poesia concreta, FRANCHETTI ainda propõe:

(...), a crise do verso e o abismo autor/público se explicam pela inadaptação do verso aos tempos modernos. À poesia parece não bastar mais a situação correta e consequente, diante da evolução das formas. A evolução das formas deve ser agora valorizada e entendida em função da apropriação e do aproveitamento dos recursos tecnológicos disponíveis, que são, ao mesmo tempo, o caminho para afirmar a poesia no mundo dos objetos industriais (ibidem, p. 187).

Poderíamos, daí, inferir que a obra coral de Gilberto também se aproxime esteticamente das mesmas ideias, uma vez que que busca incorporar elementos dessa mesma cultura dita de massa, conforme faz a poesia concreta e o grupo Noigandres, com quem o compositor sempre esteve muito ligado, trocando não só obras de arte, onde a poesia daqueles serviu de base para muitas de suas obras corais, mas também ideias e posturas diante da arte em seu tempo?

Fica transparente o posicionamento análogo do compositor em relação ao grupo Noigandres e a indústria da cultura quando ele critica essa indústria como algo que não produz senão uma pseudo-arte sem valor cultural, que nivela por baixo e tende ao ruim, ao baixo nível, à falta de expressividade e reflexão, intenção que passa longe da intenção tanto de Gilberto quanto dos poetas concretos, que é a de apropriar-se da linguagem comunicativa que a indústria possui, a fim de aproximar-se do público. Ele ainda aponta o capitalismo, o consumismo, a geração de riqueza que tal música produz como um dos pontos fundamentais para que, cada vez mais, a música erudita seja deixada de lado, posto que essa não seja passível da reprodutibilidade técnica exigida pelo mercado, e que esta característica seria exclusiva da música, pois as artes plásticas, por exemplo, podem ser vendidas, e gira muito dinheiro em torno de exibições de grandes obras de pintores famosos. (MENDES, 1994). 
Ainda em relação ao envolvimento de Gilberto Mendes com o grupo Noigandres, Carla Delgado de SOUZA (2013) afirma que essa relação vem do apoio que os poetas deram ao Manifesto Música Nova e da relação com os compositores Rogério Duprat e Damiano Cozzela. Sobre Gilberto e os concretos, a autora escreve: "Gilberto Mendes logo sentiu uma grande afinidade com a poesia concreta, sobretudo por ela ser bastante intelectualizada, ao mesmo tempo em que não abre mão de sua capacidade comunicativa." (SOUZA, 2013, p. 130). Ela segue afirmando que Gilberto via nas composições poéticas dos concretos elementos estéticos que Mendes buscava em sua própria obra: "Ao mesmo tempo em que escreve de forma inventiva, Gilberto não abre mão de procurar uma certa comunicação com seu público, (...)” (ibidem, p. 130).

A originalidade do grupo Noigandres e seu contato intenso com a produção artística e correntes estéticas da Europa e dos EUA também serviram de incentivo para o envolvimento de Gilberto Mendes com o grupo e, muito além, "serviu de modelo de inspiração para a vanguarda da música nova" (ibidem, p. 131).

SOUZA (2013) propõe a ideia da originalidade da relação entre a poesia concreta e a música nova brasileira em relação à europeia, sobretudo por que:

\footnotetext{
Muito embora tenha se interessado em realizar um tratamento musical de textos poéticos, a vanguarda europeia não tinha a seu dispor textos que tão bem dialogassem com a música serial e estruturalista, sobretudo se compararmos com o contexto brasileiro. Aqui, essa relação foi visceral, pois a musicalização dos poemas era realizada de forma a realizar ainda mais a sintaxe concreta (ibidem, p. 131).
}

Logo, a autora propõe que a relação texto-música nas obras brasileiras que utilizavam poesia concreta tem não só originalidade em relação ao que se fazia no restante do mundo, mas que tinham intrínseca relação estética e de linguagem, num diálogo artístico que fica expresso e documentado no próprio Manifesto Música Nova ${ }^{10}$.

\footnotetext{
10 "No Manifesto Música Nova, os signatários pregavam que era necessário um compromisso total com o mundo contemporâneo, com seus produtos, sobretudo as máquinas e suas formas de comunicação, somo o cinema. Valorizavam a postura concretista - concebida como contrária ao idealismo em arte e como um processo criativo que partiria de dados concretos para a sua realização. Também ressaltavam a importância da atualização e da internacionalização do debate musical realizado no Brasil - segundo eles, naquele momento particular da história do país, não mais a questão nacional deveria nortear o discurso musical a ser produzido." (SOUZA, 2013, p. 136).
} 


\subsection{POESIA CONCRETA - O GRUPO NOIGANDRES}

A história da Poesia Concreta brasileira pode ser vista como profundamente relacionada à história do grupo Noigandres, formado pelos poetas Augusto de Campos, Décio Pignatari e Haroldo de Campos, pois, ao considerarmos seus textos sobre a teoria da poesia concreta e suas obras literárias, chegaremos ao momento no qual a difusão do movimento concretista na poesia passa a tomar corpo no Brasil (FRANCHETTI, 2012). Além disso, “(...), deve-se considerar que o grupo Noigandres foi o principal (e, se se ao tomarmos um período maior, como por exemplo, 1955-1970, o único) núcleo gerador de teoria da poesia concreta." (ibidem, p. 158).

Muito embora o movimento da poesia concreta não seja um movimento literário exclusivo ou originalmente brasileiro, as diferenças e significações que esse movimento teve no Brasil são evidentes, no sentido de que obteve obras e resultados diversos em relação aos outros lugares do mundo onde o movimento concreto na literatura também teve sua expressão. Segundo FRANCHETTI (2012), embora alguns literatos afirmem uma íntima relação do movimento concretista nacional em relação ao internacional, “(...) não se demonstrou até agora a dependência da poesia concreta brasileira em relação a algum outro movimento semelhante havido no exterior, (...)” (p. 158).

Logo, embora outros autores (Ferreira Gullar, Wlademir Dias Pino, Ronaldo Azeredo, etc.) apareçam ligados ao movimento da poesia concreta, a produção do grupo Noigandres é inegável e se confunde, assim, com a história da poesia concreta no Brasil:

\footnotetext{
Não faz muito sentido, portanto, afirmar que o grupo Noigandres seja uma versão, uma parte ou facção do movimento de poesia concreta. E, abordando a poesia concreta como uma componente do processo cultural brasileiro, não há nenhum grave inconveniente em que a sua história seja compreendida como a história do grupo Noigandres, isto é, a evolução de suas ideias, suas alianças, suas desavenças, seu combate com outros movimentos que também se pretendem vanguarda, seu proselitismo, seu reconhecimento pelos meios eruditos no Brasil e no exterior. (ibidem, p. 159).
}

O início da relação entre os três poetas que compõem o grupo, Haroldo e Augusto de Campos, e Décio Pignatari, se dá no final da década de 1950, quando publicam uma série de poemas, como Auto do Possesso, $O$ Carrossel e $O$ rei menos o reino, que já transparece às tendências sobre as quais a poesia concreta se assentaria. 
Além disso, após a publicação de alguns trabalhos, os irmãos Campos (Augusto e Haroldo) começam a trocar ideias com o poeta Décio Pignatari (ibidem).

O volume n. 1 da revista Noigandres foi publicado em 1952, onde constavam obras dos três poetas do grupo. Segundo FRANCHETTI (2012), o nome Noigandres foi retirado do "Canto XX", de Ezra Pound, e cujo significado tem a ver com uma poesia ainda em formação, em construção.

A suntuosidade poética desse primeiro momento do grupo pode ser vista como um aprendizado ainda, haja vista que, “(...) alguns anos mais tarde, [os três poetas] se pretenderão sucintos, econômicos, (...)". Esse momento da poesia pode ser “(...) encarado como a diluição de sua poética.” (ibidem, p. 165-66).

O trabalho "Poetamenos", de Augusto de Campos, publicado no n. 2 de Noigandres, de 1955, “(...) marca o momento em que a poesia do grupo começa a apresentar uma significativa distância em relação às poéticas comuns à sua geração.” (Ibidem, p. 167). É nesse momento, também, que os primeiros textos sobre a teoria da poesia concreta são publicados em São Paulo.

A exposição pública de obras de pintura e poesia concreta no ano e 1956, em São Paulo, na Exposição Nacional de Arte Concreta, não ressoou de maneira escandalosa, produzindo poucos efeitos, de fato, nos meios sociais da época. Segundo FRANCHETTI (2012), muitos críticos afirmaram que as inovações às quais a poesia concreta se julgava portar não passavam de uma tentativa em impor algo que estava fadado ao esquecimento, pois não traziam inovação alguma. No ano seguinte, a exposição foi transferida para o Rio de Janeiro e causou alvoroço, com posições extremas e contrárias ao movimento por parte da crítica.

Com a simpatia de Manuel Bandeira, por exemplo, em 1957, o movimento concretista ganha não só mais corpo, como também mais discordância em relação à sua poética, resultando, daí, a ruptura de Ferreira Gullar com o grupo:

\footnotetext{
(...) Reinaldo Jardim e Ferreira Gullar, discordando justamente daquilo que era o lado mais polêmico do movimento e que acarretara para a poesia concreta a acusação de frieza e desumanidade, isto é, a formulação da poesia e do poema como técnica de linguagem, como estrutura verbal que se esgota em si mesma, ensaiam a ruptura com a poética do grupo Noigandres, o que só se consubstanciará, dois anos mais tarde, no movimento neoconcreto, de pouca duração (ibidem, p. 172).
}

Em 1960, mais o ano de 1961 - tempo em que durou a página Invenção, publicada no Correio Paulistano, esse foi o principal canal de propagação da poesia concreta naquele momento e, através desse meio, o movimento se consolidou sua 
estabilidade enquanto movimento estético dentro da literatura. Com o lançamento da referida página, os concretos intencionaram “(...) o salto para o enriquecimento semântico dos poemas, (...)” (ibidem, p. 173), que alavancou o alcance pelo esperado “(...) lugar ao sol no pequeno espaço reservado à vanguarda literária.” (ibidem, p. 173).

A participação do grupo Noigandres no cenário da literatura mundial ganha seu corpo e tônus nos anos seguintes não só com a produção de poesias novas, mas, também, com a tradução de poesias de outras línguas para o português, o que evidencia a qualidade com a qual o grupo faz as traduções e a tradução como "(...) um excelente meio de análise literária." (ibidem, p. 176).

Com o passar do tempo, a postura estética do grupo Noigandres se modifica, sobretudo sob a influência de João Cabral de Melo Neto, que chama os poetas para o dilema da separação entre o público e a poesia. Sendo assim, o grupo preocupa-se em reaproximar-se sem, no entanto, deixar de lado suas posturas e técnicas. FRANCHETTI (2012) afirma:

\footnotetext{
A relação entre a poesia concreta e a tradição e entre a poesia concreta e o mundo contemporâneo - e essa é a resposta, portanto, à questão angustiosa de como fazer coincidir a vanguarda erudita com a arte adequada ao mundo dos mass media - passa a ser uma relação regida por um 'como se'.

O poema concreto é produzido como se fosse um produto industrial; ao mesmo tempo deve ser lido como aquilo que se afirma ser: o herdeiro erudito da principal linha evolutiva da literatura ocidental (ibidem, p. 190).
}

Logo, a linguagem fácil e comunicativa da qual a poesia concreta se apropriou tem o intuito de aproximar-se do público num primeiro momento, mas, não deixando de lado sua erudição, num segundo momento, o público, ao se apropriar dos meios para uma compreensão mais profunda daquela poesia, à primeira vista, de apelo comunicativo, seria trazido a enxergar essa erudição contida na própria obra.

No entanto, atualmente, a apropriação literária das técnicas e tecnologias da indústria mostra-se, de fato, um problema, pois a evolução tecnológica da comunicação é contínua e demasiado acelerada, o que, para os poemas compostos com tecnologia já ultrapassada, significa sua ruína, no sentido em que os poemas escritos há 40 anos, por exemplo, não podem competir, tecnologicamente, com as tecnologias já disponíveis hoje em dia, o que os torna, do ponto de vista da técnica, obsoletos. Isso faz com que valorizemos mais aquela poesia mais ligada ao artesanato, ao poeta como artesão, criador de sua própria ferramenta, cuja originalidade depende única e exclusivamente do próprio poeta. Conforme propõe FRANCHETTI (2012): 
E a própria poesia concreta aparece, cada vez mais, não como a negação do humanismo - tal como ela se via e como a viam os contemporâneos -, mas, justamente, ao contrário, como um dos últimos suspiros do humanismo utópico, um momento de esplendor otimista da modernidade que findava (ibidem, p. 196).

Agora, passaremos às teorias analíticas que embasarão as análises feitas no Capítulo 3. Em nossas considerações finais, envolveremos os aspectos históricos e analíticos a fim de obtermos uma visão ampla sobre as obras analisadas e os processos composicionais de Gilberto Mendes. 


\section{CAPÍTULO 2 - DAS TEORIAS ANALÍTICAS}

As teorias analíticas utilizadas são de três naturezas. Primeiramente, as musicais, baseadas nos textos de PERSICHETTI (1978) e CAPLIN (1998); segundo, as análises de texto utilizam as ferramentas da poesia concreta, com os textos de CAMPOS (1986), CAMPOS et al. (2006) e FRANCHETTI (2012), além dos artigos resenhados neste capítulo que foram encontrados através de uma revisão bibliográfica que fizemos; e, terceiro, a teoria analítica que integra as duas artes - música e poesia -, com embasamento teórico em COOK (2004).

Este segundo capítulo se concentra, sobretudo, nas teorias da Poesia Concreta e da análise multimidiática. Achamos por bem apenas nos determos nesses dois pontos da exposição dos conceitos analíticos em virtude de, primeiramente, considerarmos a teoria da poesia concreta como secundária a este trabalho, sendo, portanto, interessante trabalharmos com as referências com as quais os textos das músicas corais à capela de Gilberto Mendes estão ligados, que são os textos citados anteriormente. Segundo, sobre os conceitos da análise multimidiática, que é propriamente o foco da análise deste trabalho, na medida em que aborda a obra de Mendes não como uma música que possui um texto, mas como uma obra que integra texto e música, onde ambos têm uma relação indissociável na criação do discurso a que se propõem.

Reiterando, o compositor Gilberto Mendes produziu, ao longo de sua carreira, muitas obras corais que utilizavam a poesia concreta de Haroldo de Campos, Augusto de Campos e Décio Pignatari, como Beba Coca-cola, COM SOM SEM SOM, dentre outras. Além da arte em comum com esses poetas e escritores, os pensamentos estéticos e vanguardistas defendidos pelo compositor e pelos poetas tinham muito em comum, sobretudo porque a escola de Damstadt representou, com Karlheinz Stockhausen (1928 - 2007) e Pierre Boulez (1925), tanto para a música quanto para os concretistas brasileiros, um marco estético que influenciou todo o pensamento criativo, tanto dos poetas como dos músicos de meados do século XX (CAMPOS, et al., 2006; FANCHETTI, 2012; MENDES, 1994).

Logo, a exposição dos conceitos, abordando também os aspectos históricos, servirá de base para nossa análise, que expõe também os processos composicionais envolvidos na música de Gilberto Mendes, assim como analisa a intersecção entre o texto dos poetas concretos e a música do compositor. 


\subsection{DAS TEORIAS DA POESIA CONCRETA}

Antes de expormos as teorias disponíveis nos livros citados, optamos por realizar uma revisão bibliográfica onde buscamos e resenhamos trabalhos acadêmicos, sobretudo artigos científicos, sobre a teoria e análise da poesia concreta.

\subsubsection{Da revisão bibliográfica}

Com o intuito de mapearmos a produção científica, incluindo nesta, as mais recentes produções sobre a poesia concreta, em seus aspectos técnicos, teóricos e analíticos, além da relação texto-música de obras musicais que utilizam a poesia concreta como texto base, fizemos uma revisão bibliográfica em bases de dados em busca de artigos científicos que tratassem do assunto.

A revisão nos possibilitará dimensionarmos o campo de pesquisa e estudo mais recente no ramo da literatura e da música acerca da poesia concreta e da relação textomúsica em obras musicais que utilizam a poesia concreta como texto base, bem como fornecerá fundamentação teórica para a análise da relação texto-música, sob uma abordagem multimidiática (COOK, 2004), das obras de Gilberto Mendes que utilizam a poesia concreta de Haroldo de Campos, Augusto de Campos e Décio Pignatari como texto base, que é a pesquisa de âmbito maior na qual essa revisão está inserida.

\subsubsection{Metodologia da revisão}

Realizamos buscas com os termos "concrete poetry", "music" e "analysis", e seus correspondentes em língua portuguesa, pois as bases são internacionais, "poesia concreta", "música" e "análise" nas bases de dados e bibliotecas Jstor, ProQuest, Project MUSE, SciELO e nos Periódicos da CAPES. Os termos foram cruzados com o comando "AND", que faz com que a ferramenta de busca de cada base procure por textos que contenham as três entradas utilizadas. As pesquisas foram feitas de abril a junho de 2013, em horários comercial e não comercial.

Depois de feitas as buscas, passamos para a fase de seleção do material, que resultou segundo os seguintes critérios de inclusão: 
- Artigos;

- Data de publicação inferior a 10 anos;

- Trabalhos que tratassem dos aspectos técnicos, teóricos e analíticos da poesia concreta;

- Trabalhos que tratassem da intersecção texto-música de obras musicais que utilizassem poesia concreta como base.

Os critérios de exclusão foram:

- Teses e dissertações;

- Trabalhos que tratassem dos aspectos estéticos e/ou filosóficos;

- Trabalhos que tratassem dos aspectos históricos e/ou biográficos;

- Trabalhos que tratassem de outras artes (música, dança, teatro, cinema, fotografia, etc.)

- Índices e catálogos;

- Data de publicação superior a $10 \operatorname{anos}^{11}$;

Feita a separação dos trabalhos excluídos e incluídos, os selecionados para a pesquisa foram fichados a fim de que uma análise de seu conteúdo fosse feita, e pudéssemos discutir as contribuições de cada texto para o campo mapeado e estudado, bem como as possíveis contribuições dentro da pesquisa maior, que é, reiterando, a análise da obra coral de Gilberto Mendes que utiliza a poesia concreta de Haroldo de Campos, Augusto de Campos e Décio Pignatari como texto base.

Os resultados foram separados em duas partes: primeiro, a exposição através de tabelas e gráficos daquilo que foi encontrado após a aplicação da referida metodologia; e segundo, o fichamento dos textos selecionados para a revisão. Desse modo, a análise dos dados mais concretos, como o volume de trabalhos encontrados, o volume da produção por data, por exemplo, e aqueles que exigem interpretação, que são os conteúdos dos textos selecionados, poderão ser observados de maneira mais clara, facilitando, pois, a discussão.

\footnotetext{
${ }^{11}$ Embora os buscadores das bases de dados dispusessem de mecanismos de filtragem por data, algumas vezes, alguns trabalhos apareciam com data superior a 10 anos, daí a criação dessa categoria de critério de exclusão.
} 
2.1.1.2 Dos resultados da revisão

Separando por buscador, obtivemos os seguintes resultados:

Tabela 1. Total de trabalhos encontrados por base de dados e biblioteca.

\begin{tabular}{cccccc}
\hline Jstor & $\begin{array}{c}\text { Project } \\
\text { MUSE }\end{array}$ & ProQuest & SciELO & $\begin{array}{c}\text { Periódicos } \\
\text { CAPES }\end{array}$ & Total \\
\hline 32 & 49 & 186 & 1 & 6 & 274 \\
\hline
\end{tabular}

Do total de trabalhos encontrados, excluímos, segundo os referidos critérios de exclusão, as seguintes quantidades, por categoria:

Tabela 2. Número de trabalhos excluídos por categoria.

\begin{tabular}{cccccccc}
\hline $\begin{array}{c}\text { Teses e } \\
\text { Dissertações }\end{array}$ & $\begin{array}{c}\text { Estética } \\
\text { e/ou } \\
\text { Filosofia }\end{array}$ & $\begin{array}{c}\text { Históricos e } \\
\text { Biográficos }\end{array}$ & $\begin{array}{c}\text { Outras } \\
\text { Artes }\end{array}$ & $\begin{array}{c}\text { Índices e } \\
\text { Catálogos }\end{array}$ & Repetidos & Data & Total \\
\hline 186 & 31 & 20 & 20 & 2 & 1 & 11 & 268 \\
\hline
\end{tabular}

O total de trabalhos incluídos por base de dados e biblioteca é o seguinte:

Tabela 3. Trabalhos incluídos por base de dados e biblioteca.

\begin{tabular}{cccccc}
\hline Jstor & $\begin{array}{c}\text { Project } \\
\text { MUSE }\end{array}$ & ProQuest & SciELO & $\begin{array}{c}\text { Periódicos } \\
\text { CAPES }\end{array}$ & Total \\
\hline 1 & 1 & 0 & 0 & 1 & 3 \\
\hline
\end{tabular}

Ao cruzarmos as informações das três tabelas, obtivemos os números relativos aos trabalhos excluídos por base de dados e biblioteca (Tabela 4).

Tabela 4. Número de trabalhos excluídos por base dados e biblioteca.

\begin{tabular}{ccccc}
\hline Jstor & Project MUSE & ProQuest & SciELO & $\begin{array}{c}\text { Periódicos } \\
\text { CAPES }\end{array}$ \\
\hline 31 & 48 & 186 & 1 & 5 \\
\hline
\end{tabular}


Ao nos atentarmos para a data de publicação dos trabalhos incluídos, obtivemos o seguinte (Gráfico 1):

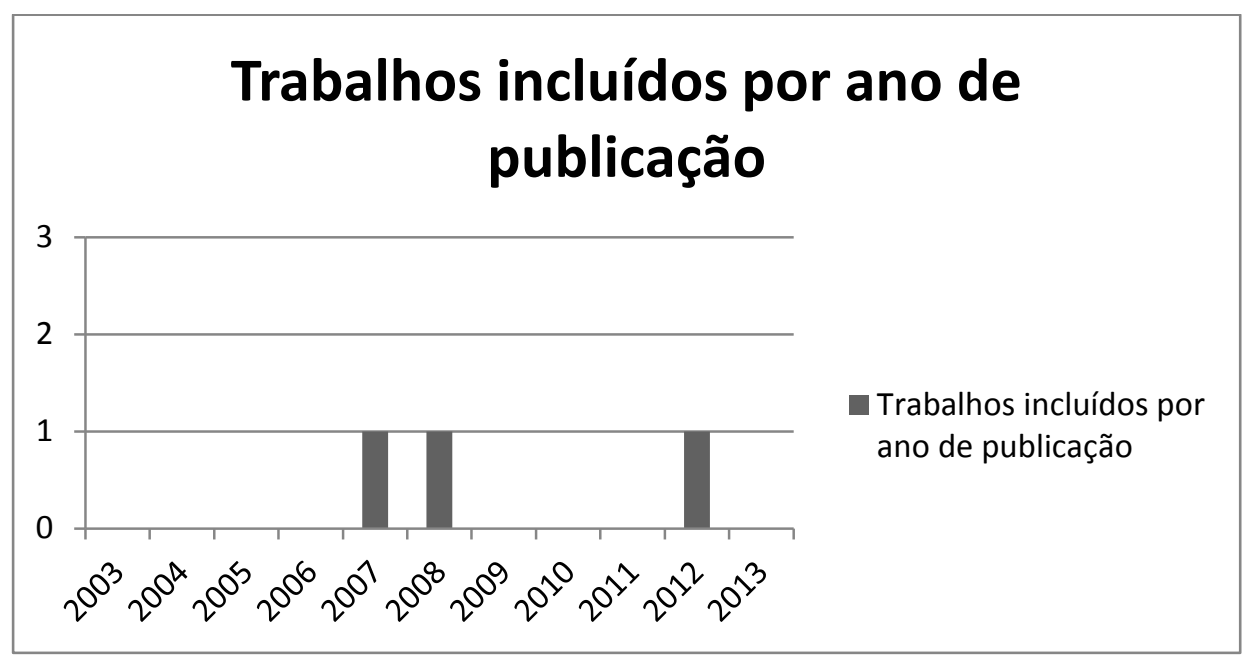

Figura 1 - Gráfico dos trabalhos incluídos por ano de publicação.

A porcentagem dos trabalhos incluídos por base de dados e biblioteca é (Gráfico 2):

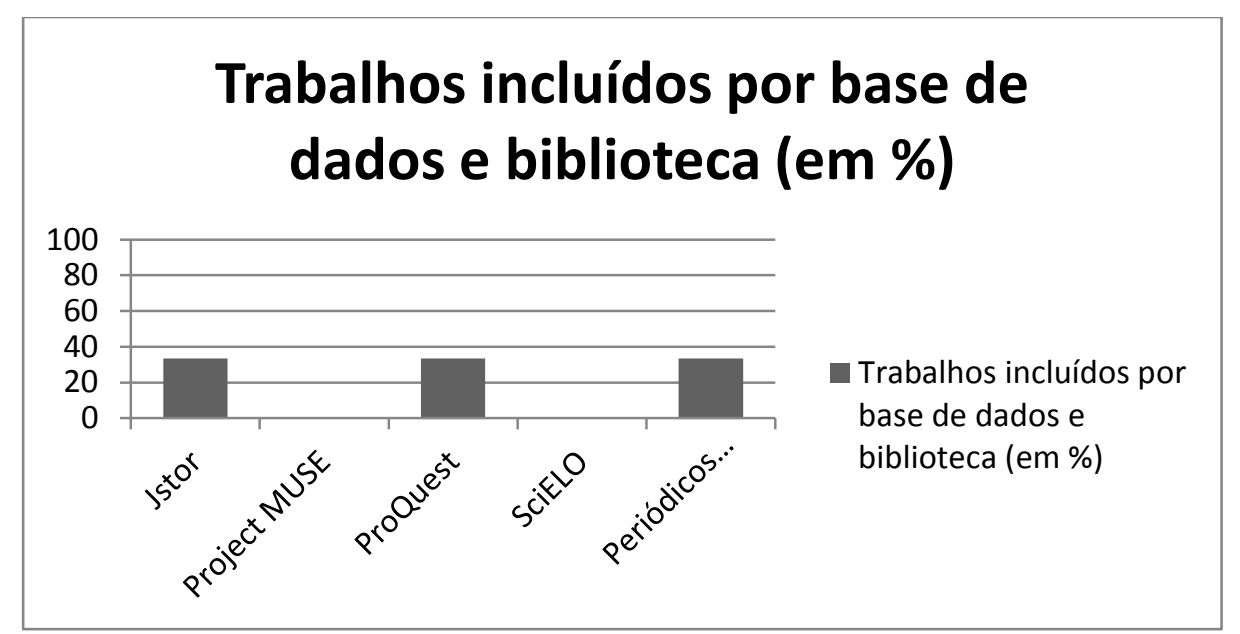

Figura 2 - Gráfico dos trabalhos incluídos por base de dados e biblioteca em porcentagem.

\subsubsection{Das resenhas para a revisão}

A resenha dos textos buscou evidenciar as características principais relativas à abordagem de cada trabalho com relação aos aspectos técnicos e teóricos da poesia concreta, subsidiando a discussão posterior: 
- COSTA, Elisa Gomes da; SIMÕES, Elsa. A tradução na poesia concreta: algumas reflexões. Repositório Científico de Acesso Aberto de Portugal. Universidade Fernando Pessoa. Porto: 2008.

Ao propor o desafio da tradução literária, sobretudo de poesia concreta, as autoras Elisa Gomes da COSTA e Elsa SIMÕES (2008) pesquisam diversos trabalhos que discorrem acerca da tradução desse tipo de obra de arte sob diversas abordagens, levantando, inclusive, questões teóricas e estéticas relativas à poesia concreta.

As autoras se propuseram a traduzir para o inglês o poema "Poesia Encontrada", de António Aragão, um poeta concreto português, a fim de trazerem à tona as questões relativas à tradução da poesia concreta. Ao problematizarem as questões relativas à tradução da poesia concreta, COSTA e SIMÕES expõem as dificuldades da tradução em si, que perpassam as questões envolvidas na conservação do conteúdo do texto em relação à valorização do sentido amplo e dos significados que o texto abrange, algo que, segundo elas, muitas vezes, não é contemplado em outros tipos de tradução. Além disso, a poesia de vanguarda possui particularidades inerentes a si mesma que passam pelo discurso, essencialmente no sentido em que a poesia, sobretudo a concreta, concentra-se no modo pelo qual a mensagem é dita, e que sobressai àquilo que é dito.

Para tanto, as autoras, inicialmente, traçam um histórico da poesia concreta. Segundo COSTA e SIMÕES, a poesia concreta é "um fenômeno literário com expressão internacional, caracteriza-se pelo seu experimentalismo a nível formal, que corresponde a uma vontade de exprimir de uma nova forma - não só linguística - uma nova realidade histórica e social." (2008, p. 58). Referenciando o poeta concreto Haroldo de Campos, as autoras definem a poesia concreta como a arte poética literária onde a palavra torna-se objeto da própria obra de arte, assumindo papel não hierarquizado em relação ao sentido que encerra em si mesma, o que torna possível a utilização de técnicas de diagramação diversas das tradicionalmente usadas pela literatura, numa aproximação com as artes visuais, como a fotografia e a pintura, por exemplo. A palavra é tolhida de sua semântica tradicional e a fruição da poesia concreta deve ser tanto visual quanto auditiva, o que eleva a mídia na qual a poesia foi produzida - o papel, por exemplo - ao status de parte indissociável e de igual importância ao conteúdo que carrega, que é o próprio poema em si. Isso propõe novas formas de leitura do poema também.

A partir desse ponto, COSTA e SIMÕES trazem o seguinte problema relacionado à tradução da poesia concreta: como sustentar a qualidade fundamental da 
tradução, que é manter o significado do texto traduzido, de um texto que, em suma, não mais contém o significado tradicional em si mesmo, mas uma nova rede semântica pressuposta na palavra não mais como um símbolo linguístico, mas como um símbolo em si mesma?

Para responder a essa questão, as autoras consideram alguns aspectos teóricos da tradução literária, como as escolhas que o tradutor é chamado a fazer em relação à tomada de decisões no momento da tradução do texto. Para elas, o processo de tradução, sobretudo da poesia concreta, deve considerar a recepção da obra literária, onde o leitor é, também, um coautor, que vai embutir suas próprias experiências na construção do sentido da obra. Outros aspectos da tradução de poesias se referem à forma da própria da própria poesia, que é modificada no idioma para o qual o poema foi traduzido em relação ao idioma no qual ele foi concebido.

\footnotetext{
quando se traduz um poema, espera-se que a sua tradução resulte num outro poema que funcione por direito próprio na língua de chegada, o que obriga a evidentes constrangimentos formais e que se prendem, principalmente, com questões de equivalência que se colocam a vários níveis (ibidem, p. 61).
}

Quanto à tradução da poesia concreta, as autoras ressaltam as dificuldades relativas à manutenção não somente da métrica e do ritmo, características do poema tradicional, mas também de como manter as diagramações que essa poesia traz, e que são responsáveis pela transmissão do significado da poesia.

COSTA e SIMÕES fazem considerações sobre as características do poema "Poesia Encontrada" que se propuseram a traduzir, como a não linearidade de leitura que a disposição gráfica da poesia traz, possibilitando ao leitor criar sua própria poesia, dependendo do modo como a leitura é feita, e seu método de composição, como recortes de jornal, que contribui para essa leitura não linear. Segundo as autoras, o próprio escritor do poema, António Aragão, propõe um modo de leitura para essa obra, no entanto, as autoras deixam claro que os modos de leitura "poderão variar quase até ao infinito conforme forem se alterando os sentidos e as combinatórias de cada leitura individual." (2008, p. 63).

Sendo o objetivo das autoras a tradução do referido poema, elas propõem um modo de leitura do poema do poeta português que leva em consideração aquelas características que o tornam semelhante a um recorte de jornal impresso para justificar a tradução, incialmente, dos textos em caixa alta que, em uma página de jornal, chamam logo a atenção do leitor. A tradução de tais partes levou em considerações as múltiplas 
construções sintáticas pressupostas no texto original e buscou manter tais relações depois de traduzido, trazendo, assim, toda a argumentação anterior em torno da problemática da tradução literária, sobretudo de poesia concreta.

COSTA e SIMÕES apontam as diversas intervenções feitas por elas no texto do poeta português, tanto a nível sintático e semântico, quanto a nível gráfico e da própria leitura do texto feita por elas - que foi baseada, inclusive, na leitura feita proposta pelo próprio autor do poema - de modo que a preservação do conteúdo inicial do poema pudesse ser mantida:

Apesar destas intervenções, optamos, sempre que possível, por manter uma grande proximidade relativamente ao texto original, de forma a não tornar a nossa mediação excessivamente visível e a deixar em aberto às possibilidades de leitura quase ilimitadas previstas pelo próprio texto (ibidem, p. 67).

Tomando-se tal postura das autoras em articulação com os argumentos trazidos por elas no texto, vemos que a preocupação com a preservação da forma põe-se em pé de igualdade com a preservação do sentido e, algumas vezes, até à frente, tendo em vista que o significado depende, também, da leitura que se faz do próprio poema, em virtude da infinidade de possibilidades propostas pela diagramação original do texto em sua língua original - no caso, o português.

As autoras concluem o texto dizendo que sua preocupação no estabelecimento de uma versão na qual a tradução pudesse ser pautada - versão baseada numa proposta do próprio autor do poema e nas premissas elencadas por elas como a base para uma tradução coerente com a natureza da poesia concreta - recriam a obra de modo a contribuir para a sua própria renovação, na medida em que reafirmam aquilo que o poema traz sobre si mesmo, numa referência metalinguística, "expondo a observação de quem lê uma inusitada coexistência do lado do avesso com o lado do direito nesta complexa tessitura textual." (ibidem, p. 68).

- ERBER, Pedro. The Word as Object - Concrete Poetry, Ideogram, and the Materialization of Language. Luzo-Brazilian Review, V. 49, N. 2, p. 72-101, 2012.

Através da análise de textos e poemas, o autor Pedro ERBER (2012) busca discutir as relações estéticas e poéticas dos movimentos concretistas e neoconcretistas, suas relações com o surrealismo e a superação da linguagem como único meio da poesia. 
Nos idos de 1950 e 1960, a poesia concreta coloca em cheque a materialidade da linguagem, discussão central também para os poetas neoconcretos, pois diz respeito ao material com o qual a poesia lida, quer seja de um ponto de vista objetivo como subjetivo. A linguagem ganha um approach com as artes visuais, e isso fica evidente na obra de Ferreira Gullar ${ }^{12}$ e Haroldo de Campos, que, embora tenham concepções sobre a linguagem completamente distintas (o primeiro, com sua visão mais imaterial e metafísica da linguagem - objeto da arte poética -, e o segundo, enxergando a palavra como um ideograma), encontram-se no mesmo movimento de vanguarda que busca novas concepções artísticas para a arte poética, no sentido de alinhá-la esteticamente aos mais diversos movimentos artísticos de vanguarda. Nesse espaço entre materialidade e imaterialidade da linguagem e, conjuntamente, da palavra em si, temos a obra de arte conceitual, misturando elementos visuais e linguísticos (ERBER, 2012).

Com a criação do livro-poema de Ferreira Gullar, viu-se surgir uma abordagem diferente no que diz respeito à recepção do poema: agora, sua performance, ou seja, a leitura faz parte do acontecer da obra de arte poética, que se traduz na temporalidade, posto que cada leitor teria seu próprio tempo de ler o livro-poema, o que resulta de performances diferentes, segundo a leitura de cada um. Essa transformação da poesia para algo além da palavra, logo, além da literatura, numa interface com as artes visuais vem de encontro com a obra do poeta japonês Kitasono Katsue ${ }^{13}$, cujas experimentações poéticas estão muito ligadas à fotografia e às artes plásticas, sempre dentro desse modelo de arte conceitual (ERBER, 2012). A obra de arte deixa de ser uma única obra (somente literatura, ou somente música, ou somente poesia, etc.) e passa a ser um conjunto de obras de arte.

A aproximação do poeta japonês Katsue com os irmãos Campos (Haroldo e Augusto) se dá não só através da obra de Ezra Pound, como, também, pela proximidade de correspondências, pois ambos se comunicavam com o poeta, discutindo estética e poética. Para Haroldo de Campos, as obras do poeta japonês estavam em perfeito alinhamento com o seu ideal de poesia concreta, sobretudo porque a língua nipônica utiliza, em sua escrita, elementos gráficos que representam uma ideia - o ideograma -, ou seja, um ideal de associação entre palavra e conceito muito mais profundo e amplo, que muito tem a ver com o aspecto gráfico e, também, gramatical, pois a lógica da

\footnotetext{
12 Poeta maranhense, nascido em 1930, fundador do neoconcretismo.

${ }^{13}$ Poeta e artista japonês (1902-1978) de influência surrealista e dadaísta.
} 
língua japonesa é diversa das línguas europeias, sobretudo em sua organização sintática (ERBER, 2012).

Muito embora a arte concreta e, conseguinte, a poesia, tenha se mostrado presente no Japão, o surrealismo, alinhado com a França, era muito mais forte, sobretudo no pós-guerra. Comparativamente ao Brasil, o surrealismo teve a mesma importância em terras nipônicas que o concretismo em terras tupiniquins. Oswald de Andrade $^{14}$, sem seu Manifesto Antropofágico, rejeita o surrealismo, assim como Mário de Andrade ${ }^{15}$ e Carlos Drummond de Andrade ${ }^{16}$, o que explicaria o florescimento do concretismo brasileiro. As duas correntes (surrealismo e concretismo) se fazem antagônicas, pois uma - o surrealismo - busca a superação da lógica pelo subconsciente sem, no entanto, superar a linguagem, enquanto que a outra - o concretismo - ocupa-se da superação da linguagem com a finalidade de atingir a objetividade na palavra (ERBER, 2012).

Embora o florescimento da arte concreta no Brasil tenha se dado em muitos campos e muitas maneiras, a pintura se distanciava dos ideais da poesia, sobretudo por buscar a máxima abstração possível na obra, enquanto que a poesia se concentrava no material - a palavra - e nas questões relativas à problemática do espaço-tempo, com aporte visual. Os poetas concretos "moved poetry away from linear temporal succession and revealed the problem of simultaneity as a decisive question of poetic compostion." 17 (ibidem, p. 87).

Buscando a não linearidade pressuposta pela poesia tradicional e pelo uso da linguagem de modo convencional, os poetas concretos se valiam dos aspectos visuais e temporais como meio de composição poética, na busca pela dissociação da linguagem de seu uso tradicional, pelo redimensionamento da palavra.

\footnotetext{
"the reduction of language to its lowest common denominator, by elimination of grammar in favor of a purely relation syntax, suggested the affinity of Concrete poetic composition with the structure of thoroughly analytic of socalled isolating languages, such as Chinese (157). The so-called Chinese model of writing served as poetic ideal, both in the sense of its recourse to
}

\footnotetext{
14 Escritor paulista (1890-1954), autor do Manifesto Antropofágico e promotor da Semana de Arte Moderna de 1922.

${ }^{15}$ Nascido em São Paulo (1893), foi escritor, poeta e musicólogo. Participou ativamente da Semana de Arte Moderna de 1922. Faleceu em 1945. Dentre suas principais obras estão Amar, verbo intransitivo e Macunaíma.

${ }^{16}$ Poeta mineiro (1902-1987) modernista. Dentre suas principais obras estão José e A última pedra no meu caminho.

17 "mudaram a poesia para longe da sucessão linear temporal e revelaram o problema de simultaneidade como uma questão decisiva de composição poética" (tradução do autor).
} 
space and visuality and in the terms of extreme reduction of grammar." (ERBER, 2012, p. 88). ${ }^{18}$

Logo, fica evidente o nível de dissociação da tradição que os poetas concretos queriam alcançar: uma nova linguagem, com estruturas semânticas diversas, utilizando as palavras legadas por essa tradição.

Segundo ERBER (2012), o modo de escrita chinês, lido pela poesia concreta ocidental, sobretudo Haroldo de Campos, foi fundamental na definição, segundo a poética concreta, do significado de ideograma. Embora a representação gráfica de um conceito pressuposta pelo ideograma como meio de comunicação, a forma como o discurso se estrutura tem um ideologia embutida - o ideograma é um conceito em si -, ponto no qual os poetas e filólogos entram em conflito, pois os poetas buscam enxergar com vistas estéticas e artísticas um fenômeno da linguagem e da comunicação.

Toda essa discussão e trajetória em torno da materialização (ou desmaterialização) do discurso e da escrita, em torno da busca de uma representação ideogramática da linguagem, da dissociação entre símbolo, signo e significado, da passagem da palavra no sentido tradicional ao objeto, que não mais necessariamente deveria ser uma palavra, mas uma imagem também levantada pelo concretismo, o neoconcretismo responde, de modo engajado, à Ditadura Militar de 1964, no Brasil. Para além das discussões estéticas e técnicas, agora, a arte veio expor a realidade, conforme pode ser observado na obra de Hélio Oiticica ${ }^{19}$ (ERBER, 2012).

- PRICE, Rachel. Object, Non-Object, Transobject, Relational Object: From "Poesia Concreta” to “A Nova Objetividade”. Revista de Letras, São Paulo, V. 47, N. 1, p. 31-50, 2007.

Rachel PRICE (2007) discute as transformações teóricas consequentes das mudanças estéticas sofridas pela poesia concreta, desde o seu surgimento até o neoconcretismo.

A poesia concreta surge, segundo PRICE (2007), num momento aonde as grandes narrativas enunciadas pela modernidade vêm ser substituídas pelo pós-

\footnotetext{
18 “a redução da linguagem para o seu menor denominador comum, por eliminação da gramática em favor de puras relações sintáticas sugeriam a afinidade da construção poética Concreta com a estrutura completamente analítica das assim chamadas línguas isolantes, como o chinês (157). O assim chamado modelo chinês de escrita serviu como ideal poético, em ambos os sentidos de seus recursos para espaço e visualidade, e em termos de extrema redução de gramática" (tradução do autor).

${ }^{19}$ Artista plástico carioca do grupo neoconcretista. Nasceu em 1937 e faleceu em 1980. Uma de suas obras mais famosas é Parangolé.
} 
modernismo, num contexto histórico já da Ditadura Militar de $1964^{20}$. A preocupação dos concretos com a forma marca uma postura apolítica, também alinhada a esse pensamento pós-moderno, e os movimentos de poesia concreta e neoconcreta não representam uma ruptura um para com o outro, mas, sim, uma continuidade, numa lógica de desenvolvimento (PRICE, 2007).

É possível enxergar uma dialética no movimento concretista, muito análogo às preocupações da Música Concreta, que pode ser observada entre o materialismo, onde a linguagem passa a ser um objeto, uma coisa, e o imaterialismo, que define a linguagem como imagem, como uma entidade virtual.

Nos primeiros manifestos, no entanto, além da postura contra o lirismo romântico e subjetivo, evidencia-se uma ambiguidade entre aquilo que seria um objeto (uma entidade, uma coisa independente, com suas qualidades próprias, tanto materiais quanto formais) e a objetividade (que se traduz na busca por aquilo que não é subjetivo, que é empírico-matemático, fim em si mesmo).

Segundo PRICE (2007), o poeta Ferreira Gullar criticou o movimento da poesia concreta por se preocupar em demasia com as questões formais e técnicas da poesia, com a "coisificação" da palavra, deixando de lado a utilidade do poema e sua recepção diante do público, que, segundo ele, deveria pressupor uma subjetividade. Essa era a postura dos neoconcretistas por excelência, representados, sobretudo, na figura de Gullar. Para os neoconcretos, a objetividade almejada pelos concretos em detrimento da subjetividade era uma postura ingênua, que alienava o grande público, devido ao seu caráter experimentalista o que, de fato, se traduz como uma ambiguidade, pois os poetas concretos almejavam um ideal de obra aberta, que muito se aproximasse da comunicação de massa (PRICE, 2007).

A referida dialética, que pode ser traduzida como uma dialética entre materialismo e imaterialismo, traz em si a vontade da busca de novas poéticas como meio do fazer artístico, da composição da poesia. O pensamento do poeta concreto Haroldo de Campos, para PRICE (2007), pode ser enunciado como a busca pela forma no próprio material, evocando uma virtualidade, o vazio. "The thing is virtual." (ibidem, p. 35). O vazio é justamente aquilo que aproxima os poetas concretos e neoconcretos,

\footnotetext{
${ }^{20}$ Golpe de Estado que destituiu o presidente eleito João Goulart (Jango) e instituiu uma ditadura militar que durou até 1985, quando foi eleito o primeiro presidente civil, Tancredo Neves, desde 1964, quando se instalou o regime militar. Muitas pessoas contrárias à ditadura foram perseguidas, torturadas e/ou exiladas pelo regime.
} 
embora a preocupação destes últimos seja justamente superar a ruptura entre sujeito e objeto.

Tal vazio representa o espaço criativo onde a obra de arte poética concretista deve ser concebida. Numa abordagem lacaniana, PRICE (2007) interpreta a vontade dos concretistas em tomar uma propagação em massa para com o público como um resultado da ressonância da voz do poeta no vazio, que é o próprio público - o outro. No entanto, tal vazio mostra-se como um ponto de contensão na linguagem, posto que o nada necessite também de definição para existir como algo real e concreto, com significação. Essa ambiguidade "enriches, rather than discredits, their work." 21 (ibidem, p. 38).

PRICE (2007) nos oferece uma série de exemplos de poemas concretos que nos confrontam com essa dualidade do objeto e do não objeto, do material e do imaterial, do real e do virtual, do vazio. Através desses exemplos a autora confirma toda a preocupação que os concretos tinham em relação ao discurso e de como a poesia concreta deveria se estruturar. A tensão dialética pode ser entendida, sugere a autora, como a contraposição entre demanda e necessidade, que é o desejo que, na poesia concreta, representa o real lacaniano.

The Real is the site of plenitude, but it must also remain a void; it cannot be filled with this or that specific content. In the Real, nothing is lacking; however it must remain open, not overwritten with symbolic description (ibidem, p. 40) ${ }^{22}$.

Logo, a função da coisa enquanto objeto determina o valor da coisa em si.

Essa busca pela coisificação da linguagem e da poesia pode ser entendida como uma crítica à própria sociedade de consumo na qual os concretos estavam inseridos, pois, a partir do momento que a obra de arte torna-se coisa em si mesma, cujo valor está agregado à utilidade que ela representa a quem a consome, embutida de uma carga simbólica, invocando o vazio, ela nos confronta com a dialética existente entra a necessidade e o fetiche (PRICE, 2007).

Nesse ponto do texto, PRICE (2007) expõe a poesia/processo, cuja ideia central se resumia na intenção de que a poesia tivesse uma linguagem universal, passível de compreensão em qualquer lugar do mundo pelo falante de qualquer idioma, através de

\footnotetext{
21 "enriquece, ao invés de descreditar, seu trabalho" (tradução do autor).

22 "O Real é o lado da plenitude, mas também deve permanecer um vazio: ele não pode ser preenchido com este ou aquele conteúdo específico. No Real, nada está falatando; entretanto ele deve permanecer aberto, não sobrescrito com descrição simbólica" (tradução do autor).
} 
uma valorização dos aspectos visuais da poesia, característica já presente nos concretistas. Tal ideal pode ser traduzido como a ênfase na performance do poema, ou seja, no seu consumo, o que se traduz como o não objeto por excelência. Logo, a proposta dos poetas da poesia/processo e do consumo demanda uma participação ativa do espectador/leitor em relação à poesia, diferentemente da poesia concreta, com uma proposta mais passiva. Fica evidente, assim, a superação do dualismo entre sujeito e objeto, por um dualismo entre consciência e inconsciência.

A superação da dialética cheio-vazio se dá através dos objetos relacionais (PRICE, 2007). Ou seja, o estado de totalidade vazia de significado engendrado no real lacaniano é substituído pelo vazio manipulável, através do qual o espectador proporá sempre uma abordagem diferente em relação ao poema, recriando-o. O interesse não está tão somente na obra do autor, mas naquilo que o outro traz consigo que influenciará e recriará a própria obra. "relational objects - would characterize a new era beyond marked distinctions between self and other, subject and object." (PRICE, 2007, p. 47). Segundo a autora, essa transição marca, historicamente, a mudança do concretismo brasileiro para um "1960s globalized future after modernism.” (ibidem, p. 48).

\subsubsection{Das discussões e conclusões sobre a revisão}

Através dos dados obtidos, podemos apontar para o fato de que o campo de estudos relativos à teoria e análise da poesia concreta não tenha se expandido muito nos últimos 10 anos, uma vez que o número de artigos encontrados sob essa perspectiva, tendo em vista o volume total de trabalhos encontrados (somados os excluídos e incluídos), não seja expressivo. Vale ressaltar que, entre os excluídos na categoria de “Teses e Dissertações", havia trabalhos que tratavam a poesia concreta sob os aspectos analíticos e teóricos, no entanto, não sendo os trabalhos de grande porte o objetivo da revisão, e que os artigos, em geral, dão visibilidade ao conhecimento produzido, os mesmos, então, foram deixados de fora desta pesquisa.

No que diz respeito ao conteúdo dos trabalhos incluídos, todos seguem a mesma linha metodológica, que consiste em apontar o problema, trazer o referencial teórico e citar algumas poesias ou excertos para exemplificar e justificar as ideias do autor. Além disso, os três trabalhos discutem, do ponto de vista histórico, o desenvolvimento da linguagem da poesia concreta ao longo dos anos em seus aspectos teóricos, técnicos e 
analíticos. O primeiro trabalho, das autoras COSTA e SIMÕES (2012), distancia-se um pouco dos outros por ser um trabalho de tradução antes de ser um trabalho que discute os aspectos teóricos e analíticos da poesia concreta, mas optamos por incluí-lo, porque as autoras fazem dessa discussão a base para o próprio trabalho de tradução.

Sendo um dos objetivos da revisão o de encontrar trabalhos que tratassem a respeito da relação texto-música em obras que utilizassem a poesia concreta como texto base, evidenciamos que nenhum trabalho do gênero foi encontrado; o que não significa que eles não existam, ou que tampouco não existam obras que unam as duas obras de arte - a poesia concreta e a música -, mas indicam, sim, a necessidade de uma ampliação do estudo na área, viabilizando, pois, o projeto no qual a revisão bibliográfica se insere: que é, reiterando, o de justamente estudar a obra coral do compositor Gilberto Mendes que utiliza a poesia concreta dos poetas Haroldo de Campos, Augusto de Campos e Décio Pignatari como texto base.

Concluímos, assim, que a revisão bibliográfica, embora seja sempre um recorte relativo a uma pequena parcela do material disponível, amplia-nos a visão daquilo que tem sido produzido, possibilita-nos deparar com material que, mesmo que não seja incluído na pesquisa realizada atualmente, mas que possa servir futuramente para outros desdobramentos da pesquisa, e que nos permita inquirir: qual a natureza principal dos estudos relativos ao campo em questão? Se olharmos os resultados das categorias dos critérios de exclusão, notaremos um volume grande de trabalhos que se encaixam exclusivamente sob os aspectos estéticos e/ou filosóficos, e também sob os aspectos históricos e/ou biográficos, o que nos leva a crer que os aspectos teóricos e analíticos não têm sido objeto de estudo, ou, pelo menos, que os trabalhos produzidos acerca desses aspectos não têm sido amplamente divulgados na forma de artigos. Além disso, é possível perceber que os trabalhos têm sido mais amplamente divulgados sob a forma de teses e dissertações, dado o grande volume de trabalhos do gênero encontrados.

\subsubsection{Da teoria da Poesia Concreta, segundo Franchetti}

Concentrando-nos sobre os aspectos teóricos descritos por Paulo Franchetti em seu livro "Alguns aspectos teóricos da Poesia Concreta" (2012), nossa intenção é subsidiar as análises do Capítulo 3. Sendo assim, nossa atenção foi voltada sobre os trechos em que Franchetti escreve sobre as poesias que Gilberto Mendes utilizou nas 
obras corais aqui analisadas, se não sobre estes textos especificamente, sobre a teoria da Poesia Concreta utilizada pelos concretos Haroldo e Augusto de Campos na criação de tais textos, de modo que, ao fazermos a análise multimidiática, ou seja, da interação entre o texto e a música, possamos trazer para a discussão tais aspectos específicos da poesia e suas implicações para a relação multimidiática na obra.

O esforço de Paulo Franchetti se concentra em, através e segundo a análise dos manifestos, textos e intervenções em congressos e encontros literários deixados por Haroldo de Campos, Augusto de Campos e Décio Pignatari, entender o projeto de Poesia Concreta e os meios pelos quais essa poesia se propaga, como se propaga, por que se propaga e para quem se propaga. Haroldo de Campos define a Poesia Concreta como

(...) composição de elementos básicos da linguagem, organizados ótico acusticamente no espaço gráfico por fatores de proximidade e semelhança, como uma espécie de ideograma para uma dada emoção, visando à apresentação direta - presentificação - do objeto (CAMPOS apud FRANCHETTI, 2012, p. 68).

Completando o raciocínio, Franchetti afirma que o projeto da Poesia Concreta pelo grupo Noigandres pretende, também, incorporar a velocidade pressuposta na comunicação de massa, além de seus elementos de linguagem como um meio de ver a contemporaneidade na Arte, pois “(...) os hábitos do homem moderno exigem que o poema se comunique rapidamente, se concentre (...)" (FRANCHETTI, 2012, p. 70). Ou seja, o projeto da Poesia Concreta prevê que a adaptação da linguagem poética deve deixar as antigas práticas da poesia do passado para, então, ao incorporar os elementos do mundo moderno, falar diretamente ao leitor de seu tempo ${ }^{23}$. Segundo Franchetti, Pignatari defendia que essa aproximação entre a Poesia Concreta e o público seria fundamentalmente alcançada através do uso da linguagem característica do mass media $^{24}$, e a espacialização do poema, o aspecto gráfico, a negação do verso e o ideograma seriam essenciais para se alcançar esse objetivo (ibidem, p. 71).

\footnotetext{
${ }^{23}$ Essa ideia vai sendo progressivamente abandonada e a incorporação da linguagem do mass media passa ter um caráter mimético (FRANCHETTI, 2012, p. 90), onde a imitação dessa comunicação de massa não visa uma aproximação com o público, mas a apropriação de elementos contemporâneos da linguagem com a finalidade de ser a Poesia Concreta algo essencialmente moderno e contemporâneo, e que dialoga com a tradição da poesia, sem, contudo, romper com essa tradição, mas, sim, superá-la.

${ }^{24}$ Mass media se refere, no texto de Franchetti, aos meios de comunicação de massa e sua linguagem sintética, rápida, curta, de efeito, que visa atingir um grande público com uma velocidade muito grande, como anúncios, propagandas, jornais, revistas, rádio, televisão e, hoje em dia, a internet e redes sociais.
} 
A incorporação dos elementos da mass media tem relação direta com 0 ideograma, cuja concepção vem da língua chinesa ${ }^{25}$, e, através do diálogo com a tradição do passado que visa à superação da lógica da linguagem, a Poesia Concreta alcançaria seu ideal comunicativo que diz sem ser literal, onde a forma está acima do conteúdo (ibidem, p. 87).

Franchetti nos expõe em seu trabalho as questões relativas às concepções da Poesia Concreta do grupo Noigandres sem, no entanto, nos mostrar as técnicas propriamente ditas. Apesar disso, ter contato com as linhas de pensamento poético por trás da concepção dos poemas concretos é muito útil na medida em que permite ao leitor se apropriar com referências desses poemas, compreendendo-os segundo o contexto no qual foram criados. Para a análise, isso implica em enxergar o poema não de uma maneira tradicional da poesia de versos, mas segundo aquilo que pretendiam os Poetas Concretos com a Poesia Concreta, possibilitando abordagens distintas sobre o poema, de modo a encontrar significados diferentes segundo essas abordagens.

\subsection{SOBRE A TEORIA ANALÍTICA MULTIMIDIÁTICA}

Para fazermos uso da análise multimidiática, nosso trabalho buscou referências no musicólogo Nicholas Cook, cujos textos tratam não só das questões multimidiáticas, como também da análise do próprio texto musical, além de questões composicionais ${ }^{26}$.

Os principais trabalhos nos quais a análise multimidiática se baseará constam do livro “Analysing Musical Multimedia” (COOK, 2004), onde a intersecção entre duas ou mais formas de Arte em uma mesma obra (as chamadas mídias ${ }^{27}$ ), os modos como elas se reforçam, se negam ou confluem, ou seja, o modo como as diferentes mídias se

\footnotetext{
${ }^{25}$ Isso significa dizer que a imagem que expressa a ideia é mais importante que a palavra, o som dela. Ou seja, em línguas que se utilizam do ideograma como forma de escrita, como o chinês, por exemplo, citado por Franchetti, a imagem diz mais sobre a ideia que os sons que ele pode conter em si para a representação dessa ideia, que é o que acontece com as línguas românicas ocidentais, por exemplo. De fato, a poesia concreta vai, assim, se ocupar da incorporação de elementos visuais para alcançar o estado de ideograma, onde a ideia está expressa através da forma e não somente das palavras, dos conteúdos (FRANCHETTI, 2012).

${ }^{26}$ Em seu livro "Analysis Through Composition", o autor propõe a visão analítica através do estudo da composição musical, enquanto que em "A Guide to Musical Analysis" o autor trata tanto da análise de música tonal quanto das ferramentas e métodos mais recentes para a análise da música contemporânea.

${ }^{27}$ Cook utiliza o termo em inglês "media" para designar as diferentes formas de arte que podem estar envolvidas numa obra multimidiática.
} 
relacionam em uma mesma obra a fim de criar significados diversos daqueles que cada mídia poderia ter separadamente, são debatidos, discutidos e analisados.

O filósofo italiano Luigi Pareyson "concebe as obras de arte como organismos vivendo de vida própria e dotados de legalidade interna, e que propõe uma concepção dinâmica da beleza artística" (PAREYSON, p. 27, 1997). Podemos, com isso, inferir que o significado da obra está contido nela mesma, posto que a obra de arte, é um todo, uma coesão, um algo acabado. Esta afirmação abre espaço para uma longa discussão a respeito de qual seria o significado de uma música, entretanto, longe da exaustão sobre esse debate, nossa intenção é oferecer subsídios para a compreensão das obras corais $a$ capella de Gilberto Mendes analisadas nesse trabalho, e da relação das mesmas com a Poesia Concreta, de modo a contribuir para a interpretação artística dessas obras e, também, para a compreensão dos processos composicionais usados pelo compositor na criação dessas obras.

Além do livro citado, outro livro de Cook, o "A Guide to Musical Analysis", os livros de Caplin (1998) e Persichetti (1978) são utilizados nas análises como referências teóricas com as quais analisamos a obra de Gilberto Mendes. No entanto, como o objetivo desse trabalho é o de abordar as questões multimidiáticas das obras do compositor, achamos por bem focarmos nossa concentração na exposição das bases teóricas que são referência para a nossa análise; no caso, "Analysing Musical Multimedia".

\subsubsection{Sobre o livro "Analysing Musical Multimedia"}

Nicholas Cook, ao lidar com a questão fundamental do significado da música já na Introdução de seu livro "Analysing Musical Multimedia", que trata da análise de comerciais de tevê ${ }^{28}$, propõe uma abordagem do significado ${ }^{29}$ da música no contexto da

\footnotetext{
${ }^{28} \mathrm{O}$ autor não trata apenas de música escrita para comercial (ele sequer inclui um jingle em suas análises), mas também de música concebida como música para outros fins que não um comercial de televisão, como a abertura "As Bodas de Fígaro", de Mozart, que foi usada para dar sentido à mensagem contida em comerciais de tevê.

${ }^{29}$ Quando falamos em significado, não necessariamente nos referimos à semantização do discurso, propriamente, mas, sim, sobre a construção do discurso independentemente se há ou não aproximação linguística entre o aquele que difunde a mensagem e seu receptor. Por exemplo, a Forma Sonata, característica do Período Clássico, possui um discurso baseado na forma que é muito evidente: dois temas que são apresentados, modificados e reapresentados com modificações, no entanto, essa narrativa não pressupõe significados específicos, como uma história de antagonismos entre dois personagens, um diálogo entre duas frentes divergentes, etc. Ou seja, a música propaga-se por seus meios de discurso,
} 
propaganda. Sobre isso, o autor diz que "The question treats meaning as if it were an intrinsic attribute of sound structure, rather than a product of an interaction between sound structure and the circumstances of its reception"30 (COOK, 2004, p. 23). Ou seja, sendo o comercial televisivo uma comunicação multimidiática, que reúne mais de uma mídia em uma única forma de expressão, não basta olharmos para apenas uma delas, no caso, a música, a fim de entendermos o seu significado. É necessário que o conjunto dessa interação seja observado e analisado como um todo, tanto em questões estruturais quanto do ponto de vista da recepção, pois é daí, segundo o autor, que emergem os significados.

Cook deixa claro na Introdução de seu livro, através da análise de inúmeros comerciais de tevê, que a música possui um papel fundamental no contexto do comercial em que está inserida. Vejamos bem: dentro do contexto do comercial; isso significa que, isoladamente, a música não produziria sobre o espectador (aquele que recebe a comunicação), o mesmo efeito, tampouco teria a música o mesmo significado de quando associada à imagem. E isso diz respeito não só à estrutura da música (suas características harmônicas, contrapontísticas, formais, etc., que integrariam um todo em si mesas, que é o todo da música, com seus próprios significados), mas à interação entre a música e a imagem no caso do comercial de tevê.

Nesse ponto, é fundamental atentarmos para outra questão: se a música de comerciais de tevê possui um significado distinto para quem a recebe daquele que ela teria quando isolada da imagem, por que o mesmo não seria válido para uma música que estivesse associada a um texto, como em uma canção ou uma obra coral, por exemplo? Sobre isso, Cook diz: "Exactely the same applies to the relationship between music and words in song. And perhaps more significantly, it applies equallly to the relationship between music and vast quantity of words that are written about music"31.

O texto, numa canção, obra coral ou obra orquestral e vocal, é indissociável da música, do contrário, o sentido criado pela união de ambos estaria perdido e, separadamente, cada um, texto e música, teriam um significado distinto. O autor reforça que as palavras são fundamentais para a compreensão daquilo que a música nos

característicos dela mesma, mas sem depender, necessariamente, de semantização linguística ou metafórica.

30 "A questão trata o significado como se fosse um atributo intrínseco da estrutura sonora, ao invés de um produto da interação entre a estrutura sonora e as circunstâncias de sua recepção" (tradução do autor).

31 "Exatamente o mesmo se aplica à relação entre música e letra numa canção. E, talvez mais significativamente, isso se aplique igualmente à relação entre música e a vasta quantidade de palavras que são escritas sobre música" (tradução do autor). 
apresenta sonoramente, ou seja, a verbalização, tanto técnica quanto imagética, metafórica, estilística e poética na tentativa de descrever o conteúdo sonoro musical são complementações do sentido que a música possa já encerrar em suas formas discursivas. Isso significa que os textos de análise também fazem parte dessa tentativa de apreender de maneira verbal o significado já contido na música e que, assim, segundo Cook, contém uma função multimidiática, complementando o sentido (já) contido na música.

A análise que Nicholas Cook faz em relação aos comerciais de tevê nos é particularmente interessante na medida em que algumas das obras de Gilberto Mendes, segundo o próprio compositor, foram baseadas nas sonoridades e ideias discursivas dos jingles publicitários (estrutura). Obras como "Asthmatour" e "Motet em Ré menor Beba Coca-cola" aludem à propaganda para criarem seu sentido, ou seja, se valem da recepção, pressupondo que o ouvinte já tem introjetado a linguagem típica dos comerciais televisivos. As descrições mais características dessas obras as expõem como sendo irônicas e irreverentes em relação à música de consumo (e, no caso, para o consumo) da Indústria da Cultura ${ }^{32}$ (BENJAMIN, 1987).

Sobre a análise multimidiática, Cook afirma que é necessário valorizar as relações existentes entre os variados meios dentro da obra, ou seja, a música, a imagem, o texto, etc. Sem isso, a análise seria incompleta, o que reforça aquilo que foi dito anteriormente: a obra multimidiática só tem seu sentido preservado quando observada a estrutura não isolada de cada mídia, isto é, na sua interação, sem deixar de lado a recepção.

Ao se tratar de análise multimídiatica, é inevitável falar-se em sinestesia, que consiste em provocar o estímulo de um sentido através de outro (COOK, 2004), como, por exemplo, enxergar cores ao ouvir uma nota musical. As teorias a respeito da sinestesia surgiram como uma pseudo-ciência, que partiam muito mais das experiências individuais daqueles que escreviam a respeito de experiências sinestésicas que da aplicação de métodos científicos para comprovar a existência de tais fenômenos psicológicos $^{33}$, e de que seus efeitos se manifestavam igualmente ou diferentemente em pessoas (idiossincrasia). No entanto, compreender a sinestesia vai de encontro com a

${ }^{32}$ Gilberto Mendes escreve que a obra "Beba Coca-cola" é, na verdade, um antijingle, ou seja, uma propaganda negativa sobre o consumo da bebida e toda essa propaganda estaria explícita não só no texto, do poeta Décio Pignatari, como na música também, invocando a linguagem característica das propagandas e comerciais publicitários (MENDES, 1994, p. 107).

${ }^{33}$ A fim de não nos atermos nas contextualizações históricas que Nicholas Cook faz, optamos apenas por citá-las. No entanto, para aprofundamentos sobre o assunto, sugerimos a leitura do Capítulo 1 do livro "Analysing Musical Multimedia", onde o autor expõe o surgimento dos estudos sobre sinestesia, que, segundo ele, estão associados ao surgimento do movimento Simbolista nas Artes. 
análise multimídiatica, pois é no limite entre os fenômenos sinestésicos e as descrições por meio de analogias onde se estabelecem as relações entre os diferentes meios que compõem uma obra. Sobre isso, o Cook diz:

(...) the similarities between synaesthesia proper and the cross-media relationships of multimedia count for less than the differences between them. Synaesthesia provides some hints as to what multimedia is; but, perhaps more importantly, it supplies an illuminating model of what multimedia is not (ibidem, p. 29) ${ }^{34}$.

Muito além de fornecer material analítico às múltiplas relações existentes entre as diferentes mídias envolvidas numa obra multimidiática, a sinestesia aliada às percepções quase sinestésicas ${ }^{35}$ propõe um meio para se enxergar tais relações. Para completar, Cook diz: “(...), multimedia is not simply externalized synaesthesia. Synaesthesia, or at any rate quasi-synesthesia, may be an enabling condition for multimedia, but it is not a sufficient one" (ibidem, p. 33$)^{36}$.

Cook diz que a sinestesia, diferentemente de estabelecer uma relação entre as diferentes mídias (música - som, imagem - visão, por exemplo), apenas reproduz em meios de apreensão e percepção (sentidos) diferentes uma mesma informação (ibidem), ao passo que, se essa barreira da reprodução é quebrada, uma relação sinestésica deixa de existir, partindo, assim, para o campo das analogias e metáforas.

As metáforas desempenham um papel fundamental no contexto multimidiático uma vez que a interação entre diferentes meios de maneira metafórica cria não só novos sentidos a ambos, como também evoca significações que não estão explícitas nas qualidades de ambos os meios. Por exemplo, o poeta Oswald de Andrade, em seu poema pílula "AMOR", associa o sentimento contido na palavra "amor" ao sentido da palavra "humor". Podemos ler essa associação, por exemplo, como evocativa dos infortúnios ou alegrias que uma relação amorosa possa trazer, resultando em alterações de humor frequentes por parte de quem ama, em relação ao ser amado. Ou seja, a metáfora por si traz elementos à tona que, no caso, só surgem a partir da interação de

\footnotetext{
34 “(...) as similaridades entre sinestesia propriamente e os cruzamentos das mídias numa relação multimidiática contam menos que as diferenças entre elas. A sinestesia provê algumas pistas sobre aquilo que a multimídia é; mas, talvez mais importantemente, ela fornece um modelo iluminador daquilo que a multimídia não é" (tradução do autor).

${ }^{35}$ Cook cita o exemplo das vogais e suas "cores" para exemplificar percepções quase sinestésicas. Quando alguém diz que uma vogal é mais brilhante que outra, não necessariamente aquele que diz tem manifestações visuais, ou seja, sinestésicas, a respeito da percepção da suposta claridade da vogal.

36 “(...), multimídia não é simplesmente sinestesia externalizada. A sinestesia, ou, em qualquer proporção, a quase sinestesia, pode ser uma condição que proporciona a multimídia, mas não é a suficiente". (tradução do autor).
} 
ambas as palavras e modificam, assim, o sentido que cada palavra tem isoladamente, fazendo surgir novos sentidos dessa interação. Não apenas pela interação entre ambos os significados das palavras, mas também por qualidades que ambas compartilham (o amor e o humor se modificam de acordo com uma dada situação e circunstância, por exemplo) é que surgem os novos sentidos que, na interação multimidiática, resultam em novas significações.

Com relação à interação entre música e imagem no cinema, Nicholas Cook diz que o som busca associar qualidades da música à imagem apresentada na tela, e essa interação metafórica entre ambas é que cria a força expressiva da cena ${ }^{37}$. Além disso, a música, embora carregue inúmeros possíveis significados em si mesma, quando associada à imagem, adquire um significado específico em virtude do contexto (ibidem, p. 83).

A interação entre duas mídias de maneira metafórica também pode ser estendida para obras corais que usem poesia como fonte textual, como as obras analisadas no Capítulo 3 desta dissertação. Ora, se a música possui suas próprias qualidades (texturais, tímbricas, harmônicas, contrapontísticas, discursivas, etc.) fica evidente que as palavras cantadas pelo coro (que pertencem a um poema com suas próprias qualidades e, quiçá, metáforas) emergirão com sentidos diferentes da interação entre as qualidades da música e do texto, não só no reforço, mas muito mais pela evidenciação de características não tão explícitas em ambas, ou seja, a diferença. Sobre isso, o autor diz: "what seems to be required for the emergence of signification in multimedia is (...) a limited intersection of attributes, as opposed to either complete overlap or total divergence." (ibidem, p. 82) (is $^{38}$ Assim, ou autor vem arrematar, afirmando que os sentidos surgem muito mais das diferenças que das similaridades de características que os meios podem apresentar entre si numa interação multimidiática.

Completando, as metáforas são usadas, numa visão mais contemporânea, como dispositivos da linguagem para a construção da realidade (ibidem, p. 83) e, sendo assim, as metáforas produzidas pelo encontro de música e imagem (ou qualquer outra mídia) também apresentarão uma forma distinta a respeito da realidade desvelada por uma interação específica entre as mídias e a cedência das qualidades de cada uma, daí surge

\footnotetext{
${ }^{37}$ Nesse ponto, o autor trata de uma abordagem baseada na visão de Eisenstein, não negando outras propostas para a interação entre som e imagem, como a de Eisler, e que foram discutidas no Capítulo 2 do livro "Analysing Musical Multimedia".

38 "Aquilo que parece ser requerido para a emersão de significados em multimídia é (...) uma limitada intersecção de atributos, assim opostas ou por completa sobreposição ou divergência total.". (tradução do autor).
} 
o significado. Para o autor: “(...); according to metaphor model (...), it [meaning] arises from the intersection between sound and Picture and the corresponding transfer of atributes. ${ }^{39}$ (ibidem, p. 85).

Para incrementar a associação da metáfora ao modelo analítico multimídia, Cook, quando aborda a questão da emoção e música, diz que a música não pode expressar sentimentos que necessitem de um objeto para existir, tampouco expressar nuances de sentimentos ${ }^{40}$. Entretanto, por suas características e qualidades (velocidade, timbre, textura, etc.), a música pode trazer emoções que sejam características exteriores e "visíveis" desses sentimentos. Nesse sentido, uma música que possua atributos que relembrem a tristeza ou a alegria pode, assim, ser considerada uma música triste ou alegre, mas não histericamente alegre ou depressiva. Tais nuances derivam unicamente do objeto sobre o qual o sentimento que depende de um objeto para existir se desenha (ibidem, p. 90).

E muito embora uma música possa existir sozinha e ser concebida sozinha, sem qualquer suporte de outra mídia (texto ou imagem, por exemplo), a palavra, o texto, se mostra sempre, segundo o autor, como um elemento fundamental na criação do sentido que a música possa ter. A associação entre texto e música surge quase que automaticamente quando se propõe uma análise, ou uma simples contextualização histórica sobre a obra a ser ouvida, e se transformou numa norma, haja vista que, tanto em salas de concerto como em encartes de CDs, as notas de programa parecem ter se tornado comuns. Ou seja, culturalmente, sobretudo com a industrialização da música, o texto foi associado à música e, na tentativa da criação de qualquer significado que a música possa ter, mesmo que ela tenha sido concebida como música isolada de qualquer texto, a palavra está sempre presente (ibidem, p. 91).

Ora, a palavra vem, então, criar as nuances das emoções que a música pode expressar, ainda que a música não expresse nada ${ }^{41}$. Quando associada ao texto, a

\footnotetext{
39 “(...); de acordo com o modelo metafórico (...), ele (o significado) surge da intersecção entre som e Imagem e a transferência correspondente de atributos" (tradução do autor).

${ }^{40} \mathrm{O}$ ódio, por exemplo, necessita de um objeto delimitado, ou seja, o objeto odiado, para existir. O ódio não pode existir por si mesmo. $\mathrm{O}$ mesmo não vale para a alegria, que independe de qualquer objeto para existir. Segundo Cook, a música não pode delinear o objeto, portanto, não pode lidar com sentimentos que necessitem de um objeto para existir, no entanto, em relação aos sentimentos que não dependem de um objeto, a música pode conter as mesmas qualidades daquele sentimento, expressando-o (COOK, 2004, p. 89).

${ }^{41}$ O Autor cita o exemplo da ária "Che farò senza Euridice" da Ópera "Orfeo ed Euridice" de Cristopher Willibald Glück (1714 - 1787) que, quando retirado o texto, possui características que provocam uma emoção distinta daquela provocada quando associada ao texto, que é tristeza. Ou seja, embora a música não seja ela mesma triste, as características latentes e a emoção insipiente que a música já carrega em si mesma vêm á tona quando da interação entre texto e música (COOK, 2004, p. 94).
} 
interação multimidiática gerará significados já latentes nas qualidades que a música possa possuir em si mesma. Sobre essa interação na construção do sentido, Nicholas Cook diz: “(...), what is involved is a dynamics process: the reciprocal transfer of attributes that gives rise to a meaning constructed, not just reproduced, by multimedia." $"$ (ibidem, p. 97).

A partir desse ponto, o autor define seu modelo de abordagem multimidiática baseado em três conceitos: conformance (conformidade), complementation (complementação) e contest (contestação). Esses três conceitos estão reunidos em dois grupos distintos: similarity test (teste de similaridade) e difference test (teste de diferença), que são testes que se aplica sobre os atributos das diferentes mídias envolvidas num contexto multimidiático, a fim de defini-las segundo um dos referidos conceitos.

Aplicando as discussões a respeito de metáfora e do papel que ela desempenha nos modelos multimidiáticos, Cook diz que metáforas que abrangem uma mesma ideia, elaborando-a sob aspectos distintos, são coherent (coerente), ao passo que as metáforas que também abrangem uma mesma ideia, elaborando-a sob aspectos similares são consistent (consistente). Isso significa que, ao dizermos, por exemplo, que "a vida é um jogo" estabelecemos uma metáfora que pode ser traduzida por "viver é brincar", de modo que elas são coerentes entre si ao definirem a vida com um mesmo sentido (jogo e brincadeira). Entretanto, ao dizermos "Só se brinca com a vida uma única vez" e "Morrer é fim de jogo", temos duas metáforas com sentido intrinsecamente ligado uma a outra na ideia de que a vida não permite testes, sem, contudo, significar o mesmo que as duas primeiras metáforas apresentadas, embora todas elas se digam respeito à primeira, pois se relacionam justamente no fato de encarar a vida como um jogo.

O teste de similaridade (similarity test) é baseado na coerência ou consistência das metáforas e, caso as metáforas estabelecidas entre as mídias dentro do instance of multimedia ${ }^{43}(I M M)$ sejam consistentes (consistent) entre si, o modelo multimidiático

\footnotetext{
42 “(...) o que está envolvido é um processo dinâmico: a recíproca transferência de atributos que confere emergência a um significado construído, não apenas reproduzido, pela [relação] multimídia." (tradução do autor).

${ }^{43}$ Cook usa o conceito instance of multimedia de maneira abreviada ao longo do livro (IMM). Esse conceito se refere à caracterização um exemplo multimidiático (COOK, 2004, p. 100). Segundo Cook, essa foi a melhor saída conceitual que ele encontrou para definir um exemplo multimidiático na medida em que não se tem uma expressão na terminologia desse campo de estudo que seja equivalente a "peça" na área de música. Ou seja, o intuito do autor é apenas definir uma obra ou excerto multimidiático sob um conceito padronizado, de modo a ser um sinônimo que sintetize o conceito de obra/excerto multimidiático.
} 
será o de conformidade (conformance), posto que a conformidade está intrinsecamente ligada à metáforas que sejam consistentes entre si (ibidem, p. 99).

Apesar de pertencer ao teste de similaridade, a coerência existente entre as mídias envolvidas num IMM pressupõe uma abordagem distinta de um mesmo aspecto, ou seja, há aí uma diferença entre as mídias, ainda que exista coerência entre elas. Isso nos leva ao difference test, que é composto pelos dois outros modelos multimidiáticos: complementation e contest (ibidem, p. 99).

O significado no modelo contest surge da contrariedade dos atributos entre as diferentes mídias, do debate entre as mídias na tentativa de uma sobrepor a outra, de modo que daí emerja o significado. Além disso, contest é intrinsecamente dinâmica e contextual (ibidem, p. 102). O modelo contest aparece, pois, da contradição (contraditory), do conflito entre as diferentes mídias envolvidas no IMM e “(...) implies an element of collision or confrontation between the opposed terms." ${ }^{44}$ (ibidem, p. 102). A contradição surge necessariamente do confronto, da oposição entre elementos das diferentes mídias. O modelo contest é oposto ao conformance sobretudo porque "Conformance begins with originary meaning, whether located within one medium or diffused between all; contest, in the other hand, ends in meaning."

Já o modelo complementation depende de elementos contrários (contrary) para a sua existência, o que equivale a dizer que eles não são contraditórios, uma vez que não disputam entre si atributos para suplantar os elementos opositores, mas são, sim, elementos nas mídias que nem são consistentes ou contraditórios, e que, embora contrários, não se contradizem justamente por desempenharem “(...) a separate role"46 (ibidem, p. 104). Segundo Cook, dada a natureza independente das mídias e de seus atributos, os significados emergem, no modelo complementation, da interação entre ambas as mídias, complementando os sentidos de uma e outra nos espaços $(\text { gap })^{47} \mathrm{em}$ que elas não falam por si mesmas e que, sendo ocupados pelos atributos da outra mídia, se complementam. Isso nos leva a concluir que a interação multimidiática nesse modelo é contextual, pois depende exclusivamente dos atributos das mídias, de suas relações e dos significados que possam emergir daí numa dada interação.

\footnotetext{
44 “(...) implica num elemento de colisão ou confronto entre os temos opostos” (tradução do autor).

45 "Conformidade começa com o significado original, seja localizado dentro de uma mídia ou difuso entre todas elas; contestação, por outro lado, termina no significado.” (tradução do autor).

46 “(...) um papel diferente.” (tradução do autor).

${ }^{47}$ Nas páginas 104 e 105 de "Analysing Musical Multimedia", Cook (2004) usa a palavra gap para exemplificar justamente os espaços que podem existir, segundo uma série de autores que ele cita, numa mídia e outra onde, diante de uma interação mulltimidiática (IMM), uma pode complementar o sentido da outra.
} 
Ainda em relação aos modelos, Cook fala sobre denotação e conotação. Segundo o autor, “(...) denotation and connotation are not attributes of one medium or another, but functions which one medium or another may fulfill in any given context."48 (ibidem, p. 120). Isso quer dizer que o sentido de conotação e denotação depende muito mais da relação contextual na qual uma mídia está inserida, do que está ligado a seus atributos intrínsecos. Vale dizer, então, numa obra em que uma música associada a um texto possa ser conotativa, e o texto, denotativo numa determinada passagem onde os atributos de cada um assim os desenham em suas relações mútuas, o inverso pode valer em outro momento. Por exemplo, numa passagem musical de uma canção que fale de atos heroicos, a música pode conotar tal heroísmo através de seus atributos que, associados às denotações das palavras, criem a ideia de heroísmo em questão. Entretanto, num outro momento da mesma obra, a música que antes conotava o heroísmo, devido às relações de significância já estabelecidas anteriormente, pode denotar o referido afeto, ainda que o texto conote explicitamente um esforço heroico em vão. Ou seja, as habilidades conotativas e denotativas de uma ou outra mídia envolvidas num IMM são contextuais (ibidem, p. 120).

Ao falar sobre o princípio de primazia ${ }^{49}$, Cook traz para a discussão a questão da relação entre texto e música na ópera como um ponto de emersão da expressividade (ibidem, p. 107). Segundo o modelo platônico proposto pelo autor, o texto e a música devem seguir o ritmo natural da fala, e essa abordagem foi central durante quase toda a História da Música Ocidental. Entretanto, a música, conforme se pode ver pela prática de compositores que escreviam ópera, ganha sempre um destaque em relação ao texto, sobretudo quando o compositor faz uso de uma mesma música para vários textos diferentes. Cook afirma que tal prática de subordinação do texto à música surge a partir da leitura que o compositor tem do texto de modo a compreender as qualidades musicais que o libretto já contém em si mesmo. Finalmente, para Cook, a primazia de uma mídia sobre a outra não deve ser tomada como um fim em si mesma, do ponto de vista analítico, mas deve ser entendida no contexto dos três modelos multimidiáticos propostos, de modo que seja um fator de caracterização das relações das diferentes mídias na criação da expressividade (ibidem, p. 112).

\footnotetext{
48 “(...) denotação e conotação não são atributos de uma mídia ou outra, mas funções que uma mídia ou outra podem preencher num dado contexto." (tradução do autor).

${ }^{49} \mathrm{O}$ termo usado por Nicholas Cook é primacy (COOK, 2004, p. 107) e é relativo à subordinação de uma mídia em relação à outra, sobretudo em relações intermidiáticas, ou seja, onde as diferentes mídias envolvidas numa mesma obra não têm relações intrínsecas entre si mesmas, não dependendo, assim, da interação e transferência de atributos entre umas e outras para a criação da expressividade.
} 
Portanto, para Cook, a análise multimidiática deve, assim, se concentrar na interação entre as diferentes mídias em uma obra, de modo a enxergar suas diferenças separadamente, através da análise individual de cada uma, de modo que, após um olhar sobre os atributos de cada mídia, o conjunto e a interação entre as mídias possa ser também analisado em sua interação multimidiática e verificado, pois, os resultados dessas interações. 


\section{CAPÍTULO 3 - DAS ANÁLISES}

Apresentaremos, a seguir, as análises das obras selecionadas: Tempo Tempo, $\mathrm{O}$ Sol de Maiakóvski, TVGrama I - Tombeau de Mallarmé e O Anjo Esquerdo da História, Uma Vez Uma Vala.

Após a edição das obras, cada uma foi analisada em seus aspectos harmônicos, contrapontísticos, formais e estruturais, e em suas relações texto-música, ponto sobre o qual nossa análise tem o foco principal, no sentido de que é nesse ponto onde o conceito multimidiático proposto por nosso trabalho se aplica. A intersecção entre as duas formas de arte, Música e Poesia, ao estabelecerem relações mútuas, criam outros significados além daqueles já respectivamente encerrados nelas mesmas, quando isoladas uma da outra, ou seja, criam uma relação multimidiática.

Nossa intenção não é esgotar a análise da obra, tampouco finalizar o assunto acerca da abordagem analítica multimidiática ${ }^{50}$ de qualquer obra que una duas ou mais formas de arte em si mesma, mas, sim, contribuir para que os processos composicionais do compositor Gilberto Mendes usados na composição dessas obras, segundo os aspectos apreendidos por nossa análise, possam ser evidenciados, contribuindo para o estudo e interpretação dessas obras. Além disso, esperamos que, através da edição dessas obras corais, que se encontravam somente em forma de manuscritos, tais trabalhos do compositor possam encontrar mais espaço dentro do repertório dos corais no Brasil, e que tenham maior circulação pública.

\subsection{ANÁLISE DA OBRA “TEMPO TEMPO”}

Abordando a temática da contraposição entre o tempo cronológico e o tempo lógico, a obra "TEMPO TEMPO”, para coro e solistas à capela, traz a releitura de Eclesiastes pelo poeta Haroldo de Campos e a música de Gilberto Mendes que, através de inúmeros recursos sonoros e texturais possibilitados pelas vozes de um coral, recria, musicalmente, a dialética contida no texto.

\footnotetext{
${ }^{50}$ Reiterando, o objetivo do nosso trabalho é analisar as relações multimidiáticas na obra coral à capela de Gilberto Mendes, por isso, em cada análise, na seção que trata da relação texto-música, utilizaremos, conforme expostos no Capítulo 2, os conceitos de Nicholas Cook (1998) em seu livro Analysing Musical Multimedia.
} 


\subsubsection{Harmonia}

Harmonicamente, esta peça se define muito mais pelo contraponto de texturas, sobretudo na oposição entre coro e solistas, que pela função estrutural que os acordes representam. O uso insistente de microtons, conforme orientado pela bula da peça e

pelos clusters $^{51}$ escritos na partitura (Quadro $\mathrm{E}^{52}$ ) dissolve as relações intervalares no sentido harmônico tradicional.

O uso inicial das notas Lá e Si no Quadro B (Figura 3) define todo o espectro de alturas definidas do início da obra, até a introdução do acorde do Quadro D, que amplia esse espectro. O contraponto quase canônico do Quadro B joga com os intervalos de segunda e sétima e nona formados da defasagem resultante dos cânones de cada uma das linhas em separado. Esse jogo é reafirmado no Quadro C, onde o cânone cessa e as vozes cantam, em intervalos de segundas maiores e sétimas menores resultantes das oitavas entre vozes masculinas e femininas, de maneira homorrítmica.

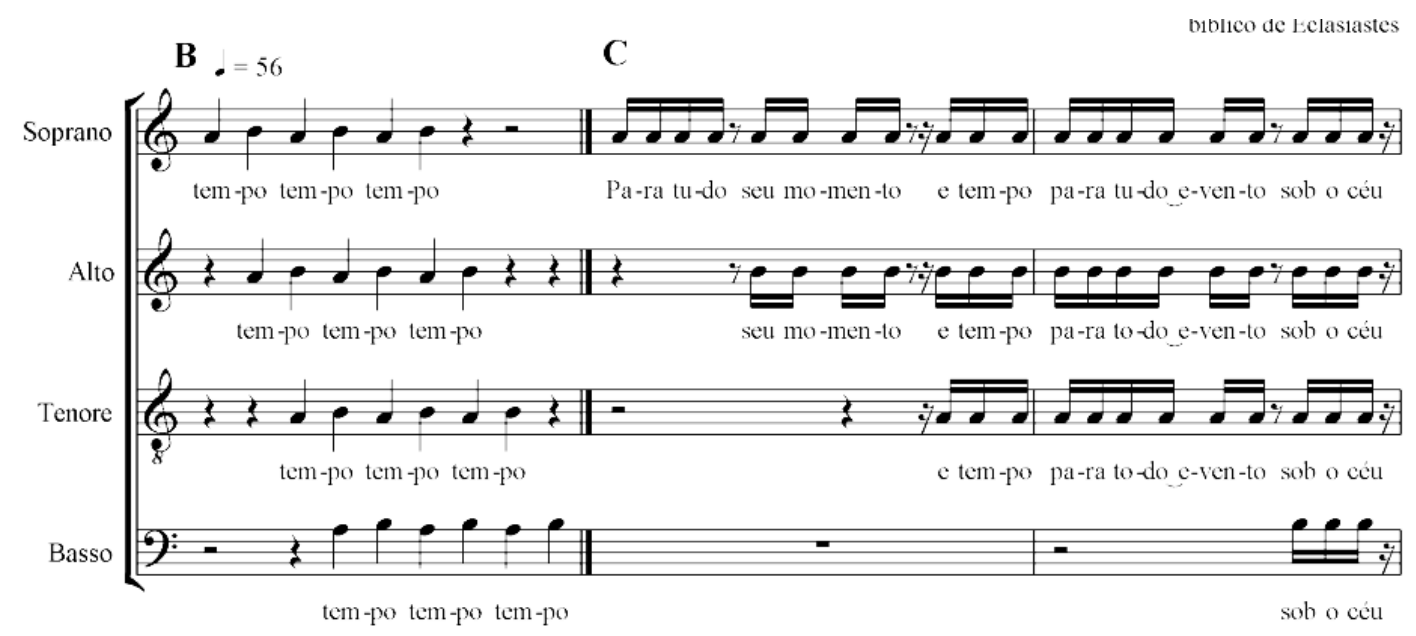

Figura 3 - As notas Lá e Si, que resumem as alturas definidas do início da peça.

A exceção está no quadro F (Figura 4), cuja harmonia resulta de acordes formados pelo empilhamento de quartas e quintas, no entanto, invertidos, ou seja, o primeiro acorde do Quadro F é construído pelas quartas Si-Mi-Lá-Ré, enquanto que o segundo, pelas quintas Ré-Lá-Mi-Si, evidenciando que, embora as notas não apareçam nessa ordem, os acordes são construídos sobre esses intervalos porque, no primeiro

\footnotetext{
51 "Grupos de notas vizinhas (geralmente tons e semitons) executadas em bloco como um acorde" (DOURADO, 2004, p. 85).

${ }^{52} \mathrm{Na}$ bula da obra, o compositor chama de "Quadros" a cada um dos trechos contidos na partitura e assinalados por uma letra de ensaio. A execução segue uma forma específica, também determinada na bula, que não aquela da sucessão tradicional dos acordes.
} 
acorde, o intervalo de quarta (guardadas as oitavas) entre Baixo e Soprano é muito evidente, já no segundo, os dois intervalos de quinta existentes entre Baixo, Tenor e Contralto são muito evidentes.

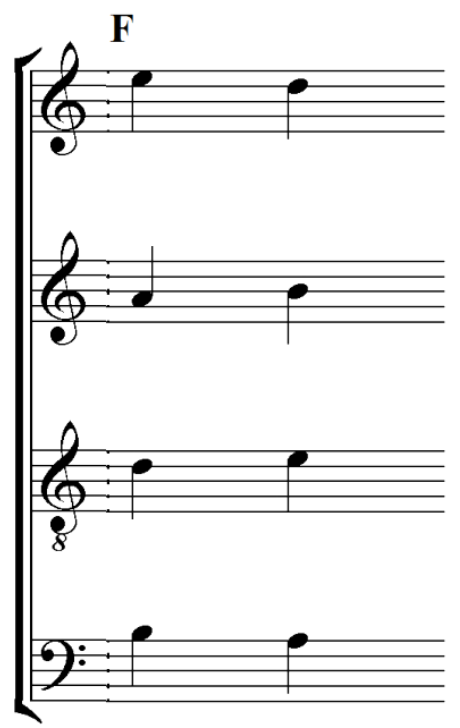

Figura 4 - Acordes por empilhamento de quarta e quinta.

No quadro G, as notas não formam propriamente um acorde, pois o intervalo formado nas vozes masculinas, Tenor e Baixo, acrescido dos solistas, é apenas reproduzido uma oitava acima, simultaneamente nas vozes femininas, Soprano e Contralto, acrescido dos solistas. De fato, a redução do número de notas diferentes a duas notas (Si e Fá sustenido no primeiro tempo, e Dó sustenido e Mi no segundo) faz referência ao início da própria peça, construído sobre o intervalo melódico de segunda maior (notas Lá e Si), cantado em oitavas entre vozes femininas e masculinas.

\subsubsection{Contraponto}

A construção do contraponto na peça se dá, num primeiro momento, através do recurso de múltiplas vozes, caracterizando um fugato, reforçado não só pela multiplicidade de linhas, mas, também, pela multiplicidade textual.

Num segundo momento, o contraponto é textural no sentido em que se contrapõem acordes estáticos, tanto microtonais quanto de alturas de notas, a linhas que se movem sem grandes movimentações melódicas de saltos. 


\subsubsection{Forma e estrutura}

Basicamente, a obra está dividida em dois momentos:

1. Quando o coro e os solistas constroem contrapontos em estilo de fuga, guiados pelas diretrizes contidas na bula e pelo regente;

2. Quando o contraponto dá espaço à estaticidade dos acordes, tanto de notas quanto microtonais, e o contraponto se dá através da contraposição entre coro e solistas, que executam melodias externas aos clusters;

A peça, assim, pode ser considerada como construída em forma binária, ou seja, em duas partes, mas sem recorrência alguma ${ }^{53}$. Reforça a tese da divisão binária a informação contida na bula da própria obra, onde a diretriz para a execução dos acordes microtonais é iniciada após a quebra produzida por uma pausa súbita.

Na partitura, existem seis partes distintas - que o compositor chama, na bula, de Quadros - (Quadros B a G), além da introdução (Quadro A, não escrito na partitura, mas descrito na bula), mas que não são executas de uma vez. Sua execução está descrita na bula, ou seja, a bula é que define a execução da obra, e não a partitura.

Nomeadamente, o compositor designa o Quadro A como Introdução, que possui apenas sons falados e efeitos de vocalização, sem notas definidas. A partir do Quadro B, as alturas definidas são introduzidas pelos solistas, de maneira amalgamada, como se a linha de cada voz solista surgisse entre as partes faladas da Introdução.

No Quadro C, os solistas realizam um fugato, recitando, com alturas definidas e homorritmicamente o texto do poema de Haroldo de Campos, enquanto o coro segue direto para o Quadro D, após algumas repetições do Quadro C pelos solistas, ou seja, a junção dos Quadros C e D exerce a função de transição entre a parte contrapontística da obra e a sua parte mais homorrítmica e estática, com acordes de notas longas e clusters. Embora o autor deixe explícito na bula que o Quadro D é central na obra e que deve durar bastante, o que o caracteriza como uma transição entre as partes é a dissolução do material da seção anterior - jogos de vozes em fugato - e introduzir o material da próxima seção - clusters e acordes - é que ele se caracteriza como uma transição entre as partes.

\footnotetext{
${ }^{53}$ Segundo Caplin (1998, p. 87), o binário recorrente (rounded binary), além de evidenciar uma forma bipartida, no início de sua segunda seção não guarda estreita relação motívica ou de material com o tema inicial da primeira seção.
} 
Os Quadros F e G, executados pelos solistas, são sobrepostas ao Quadro E, criando, assim, um contraponto de texturas. É interessante notar que os efeitos de vozes faladas permanecem durante toda a obra através das partes corais, que cantam as notas com alternâncias fonéticas que modificam o timbre dos acordes dos Quadros D e E no decorrer da execução. Vale mencionar que tal mudança ocorre na individualidade de cada cantor dentro do coro, de modo que a textura de timbres seja extremamente variada dentro da unidade maior que é o coro.

Fraseologicamente, não encontramos uma melodia ${ }^{54}$ que possa ser definida nesta obra, mas se pensarmos em questão da contraposição de texturas e nas duas grandes partes na qual a obra está dividida, a primeira, composta principalmente por partes contrapontísitcas entre as vozes, composta pelos Quadros B, C e D, e a segunda, pelos Quadros D, E, F e G, que funcionam de maneira contrastante, como se houvesse um antecedente baseado no contraponto e um consequente baseado na textura de acordes estáticos $^{55}$.

Vale reforçar que a estaticidade dos acordes da segunda parte é alcançada aos poucos, com a passagem gradual das vozes solistas e de cada voz de dentro do coro de um Quadro a outro, como se um Quadro surgisse de dentro do outro, como se um já estivesse contido no outro.

\subsubsection{Relação texto-música}

O texto traz inúmeras repetições da palavra "tempo", em notas e sílabas tão longas quanto o possível, que é cantada, sobretudo, pelo coro, ou seja, a ideia de infinitude e inexorabilidade do tempo ficam a cargo das partes corais. Já o tempo cronológico, aquele que é perceptível, mensurável, e a realidade, descrita em ações pelo próprio texto - ideia que pode ser notada na presença dos inúmeros verbos (nascer,

\footnotetext{
${ }^{54}$ Para Schoenberg (1967, p. 16), uma construção melódica, além de ser baseada numa sucessão de intervalos melódicos, deve obedecer a uma série de construções motívicas específicas, intimamente ligadas uma a outra, baseadas na essência do material com o a qual tais construções são feitas, além de se relacionar com a harmonia, de modo que o todo faça sentido e seja compreensível. Além disso, o conceito de melodia está intimamente relacionado à capacidade melódica da frase de ser cantável, mesmo em melodias escritas para instrumento, visto essas terem sido adaptadas a partir das primeiras (SCHOENBERG, 1967, p. 97).

${ }^{55}$ Antecedente e consequente são partes de um mesmo período (SCHOENBERG, 1967, p. 25). Isso quer dizer que se trata de duas melodias relacionadas uma a outra por suas construções motívicas, onde a primeira, - o antecedente - determina aquilo que vem depois - o consequente, tanto melódica quanto harmonicamente (SCHOENBERG, 1967, pp. 25-31)
} 
plantar, morrer, arrancar, etc.) cantados ao acaso sobre o acorde do Quadro D - fica a cargo dos solistas, que são um grupo menor e que, musicalmente, se contrapõe ao coro. Ou seja, a dualidade entre o tempo inexorável e o tempo cronológico, mensurável, pode ser entendida através da contraposição do coro e solistas.

Assim, temos duas metáforas simultâneas entre o texto e a música:

1. A palavra "tempo" sempre sobre notas longas;

2. Os versos do poema contendo os verbos sobre as figurações rítmicas rápidas.

Aplicando o similarity test, podemos observar que há consistência (consistent) na transferência dos atributos entre as mídias, pois as notas longas são uma metáfora para a ideia da inexorabilidade do tempo. Sendo as notas muito longas, fica muito difícil perceber a dimensão em termos de duração que elas possam ter (o que não significa que não se possa perceber seu início ou fim). Isso nos leva ao modelo conformance, que é criado pela conformidade dos atributos e as transferências entre as duas mídias envolvidas.

Os versos do poema cantados sobre figurações rítmicas mais curtas, ao passarem pelo similarity test, estão também consistentes (consistent) entre si, porque as notas curtas criam movimento, e isso vai de encontro com aquilo que os versos do poema dizem, onde há verbos, que indicam ações ou fenômenos da natureza e onde a narrativa do poema se desenvolve, o que nos leva ao modelo de conformidade (conformance) entre as mídias.

Nessa obra ainda é interessante notar o contraponto existente entre coro e solistas. O coro conduz a metáfora da inexorabilidade do tempo, e os solistas detêm a narrativa do poema. Existe, assim, uma oposição de ideias, onde numa o tempo passa, e noutra o tempo é estático, ou passa de modo tão lento que é quase imperceptível, ou é um tempo tão longo que não pode ser medido. Se aplicarmos o similarity test, veremos que não há consistência entre ambas, pois embora tratem do mesmo assunto (tempo), as duas abordam a ideia de maneira distinta. Sendo assim, partimos para a coerência (coherent), que nos leva ao difference test. Nesse teste, o modelo de contradição não se aplica, pois não há negação entre as partes de coro e solista (isso envolve tanto música quanto texto), mas estas se intervalam ou surgem uma de dentro da outra e, no final, se unem na execução dos Quadroe F e G. Isso nos leva a concluir, assim, que existe nessa 
obra uma complementação (complementation) entre as mídias e, além disso, entre as metáforas criadas pelas mídias, através da contrariedade (contrary) das mídias.

\subsection{ANÁLISE DA OBRA "SOL DE MAIAKÓVSKI”}

A obra "Sol de Maiakóvski" une o poema de Augusto de Campos, tradução da poesia homônima do poeta russo Vladimir Maiakóvski ${ }^{56}$ (1893 - 1930), e a música do compositor Gilberto Mendes, que recria, musicalmente, na sonoridade do coro misto à capela, a irreverência contida nas palavras do poeta.

\subsubsection{Harmonia}

A harmonia desta peça é baseada exclusivamente no uso da escala pentatônica com algumas alterações cromáticas que resultam na chamada Escala Blues ${ }^{57}$ (Figura 5). A escala pentatônica escolhida por Gilberto Mendes para a construção da harmonia foi a Diatônica no quinto modo (PERSICHETTI, 1978, p. 50), no entanto transposta para a base de Ré bemol (Figura 5). Corrobora para tanto o salto inicial do Baixo (Figura 6), uma quinta descendente, Lá bemol Ré bemol, como se estabelecesse a relação de tensão - nota Lá bemol - e repouso - nota Ré bemol.

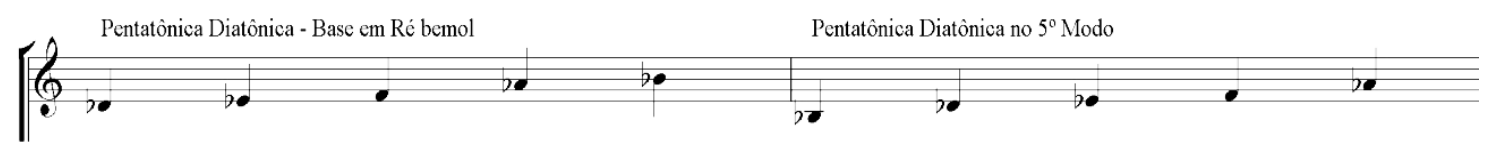

Figura 5 - Escalas pentatônicas que baseiam a obra.

\footnotetext{
${ }^{56}$ De fato, o poema de Augusto de Campos não é uma mera tradução, mas uma recriação, incluindo metáforas e palavras que não existiam no original de Maikóvski, em russo, traduzindo, muito além das palavras, os sentidos do poeta eslavo (BONVICINO, 2012), e fazendo uma ponte com os ideais poéticos movimento concretista brasileiro, cuja incorporação de elementos da propaganda e do mass media (FRANCHETTI, 2012) se fazem evidentes nesse poema.

57 "Variedade de escalas empregadas pelos BLUESMEN, cuja raiz provavelmente finca raízes na África, cuja forma mais comum correspondente à ESCALA PENTATÔNICA com o terceiro grau alterado ascendentemente" (DOURADO, 2004, p. 121)
} 


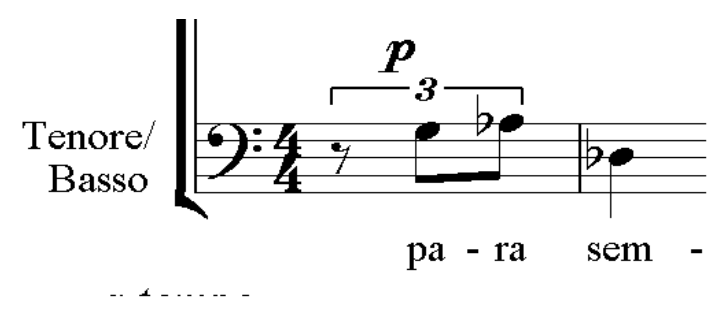

Figura 6 - Salto de quinta do Baixo.

As chamadas blue notes ${ }^{58}$, ou seja, as alterações cromáticas (Figura 7) ocorrem no terceiro grau, gerando ambiguidade quanto ao uso da pentatônica Diatônica e da pentatônica Kumoi, tanto com base em Ré bemol, quanto com base em Si bemol, omitindo-se a nota Dó (PERSICHETTI, 1978, p. 50), como se ambas estivessem sobrepostas; no terceiro grau, com o uso da nota Sol bemol, enarmonicamente, Fá sustenido; e, no quarto grau, com a nota Lá natural, além da nota Sol natural na voz do Baixo.

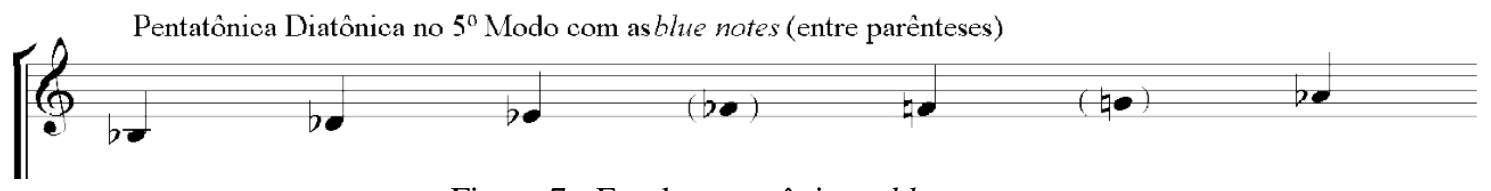

Figura 7 - Escala pentatônica e blue notes.

É curioso notar que o acorde final da peça é construído com a nota fundamental da escala pentatônica (Ré bemol), com a nota fundamental do quinto modo (Lá bemol) e com todas as blue notes utilizadas para alterar cromaticamente a escala pentatônica e criar a escala Blues. Ou seja, o acorde final é construído com as dissonâncias, mas sobre as bases da escala, como se resumisse a harmonia da obra toda, evidenciando a ideia do compositor do uso de tensões e cromatismo numa escala que, por excelência, não possui tensões nem cromatismo, dado seu diatonismo que não permite direcionalidades, que é a escala pentatônica (PERSICHETTI, 1978). A fim de evitar a estaticidade, Mendes lança mão de notas para não só embelezar a escala, como criar movimento harmônico.

Apesar do uso sistemático das blue notes, as mesmas não têm caráter de raízes harmônicas, sendo apenas notas de embelezamento. Reforçam essa tese os acordes iniciais das frases, que contém sempre as notas pertencentes à escala pentatônica. Apesar de as frases terminarem com a presença da nota Sol bemol no acorde, que não pertencente à escala pentatônica, podemos tomar esse acorde como uma semicadência

\footnotetext{
58 “A palavra blue, que define sentimentos melancólicos, deu origem ao gênero musical homônimo. Sons característicos do blues norte-americano, as blue notes consistem em certo desvio descendente na afinação de determinadas notas da escala, como a terça, a quinta e a sétima, expressando tristeza" (DOURADO, 2004, p. 52).
} 
(Figura 8), que termina em aberto, pedindo a continuidade da peça na próxima frase , quebrando, assim, a falta de direcionalidade da própria escala pentatônica.

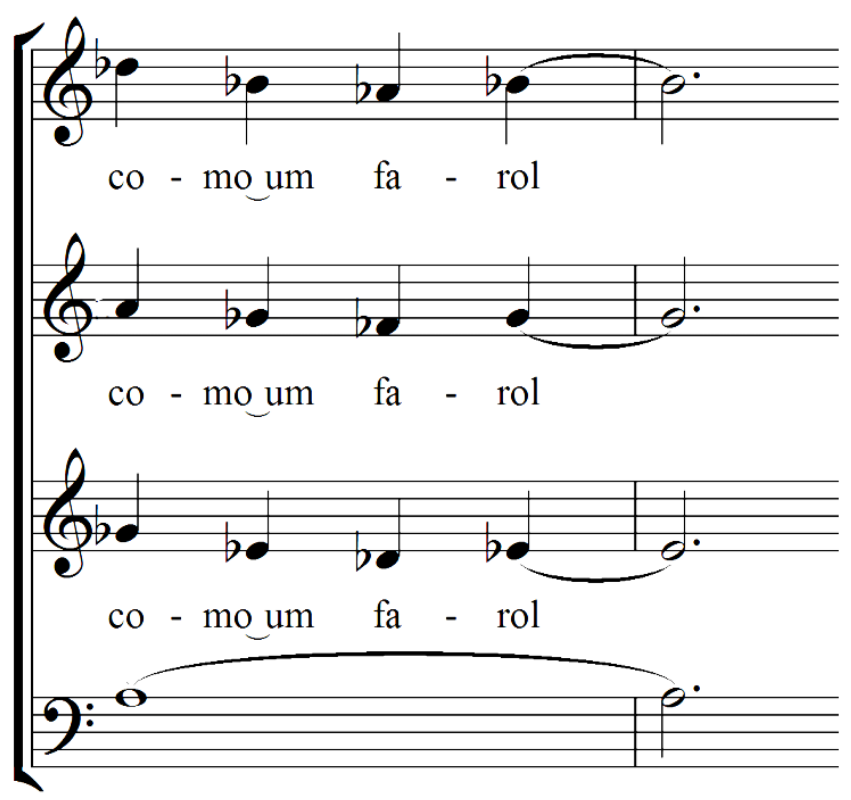

Figura 8 - Semicadência

\subsubsection{Contraponto}

Contrapontísticamente, a obra se vale da homorritmia, trazendo muito da sobreposição paralela de linhas, característica das orquestrações jazzísticas ${ }^{59}$. Ou seja, as linhas são construídas independentes, como em um contraponto, mas com a mesma direção melódica e mesmo ritmo. De fato, o contraponto se realiza quando os movimentos melódicos das vozes são independentes entre $\mathrm{si}^{60}$; isso significa que vozes em movimentos paralelos não pressupõem um contraponto, mas sim um colorido orquestral criado pela execução simultânea e paralela da mesma linha transposta em

\footnotetext{
${ }^{59}$ Em seu livro “Arranjo”, Carlos Almada (2000) define as aqui referidas orquestrações jazzísticas como técnica soli de escrita. Segundo o autor, essa técnica vem das práticas corais do Renascimento e que, ao longo do tempo, foi adaptada à escrita instrumental, passando, assim, para o jazz, tornando-se uma característica textural desse estilo musical. O dobramento da linha em intervalos fixos e paralelos (ou com pouca movimentação melódica entre as vozes), com movimento rítmico idêntico (homorritmia) são as principais características dessa técnica.

${ }^{60} \mathrm{O}$ termo latino para a definição de contraponto (punctus contra punctum) deixa explícito não só a prática de se executar uma nota contra a outra, mas também seu caráter independente, na medida em que sobrepõe linhas melódicas autônomas, quer seja de uma maneira mais simples - organum livre - ou mais complexa - polifonia renascentista a cinco vozes, por exemplo (TRAGTENBERG, 1994, p. 15).
} 
intervalos diferentes (neste caso, os intervalos variam entre terças maiores e menores) ${ }^{61}$. No entanto, os movimentos cromáticos existentes entre as vozes como, por exemplo, nos Compassos 1 e 2, entre Soprano II e Contralto, criam um contraponto sutil, exaltado pelo timbre, que é diferente entre os naipes.

\subsubsection{Forma e estrutura}

A obra é monotemática. A frase dos quatro primeiros compassos é repetida quatro vezes, com algumas pequenas alterações rítmicas nas terceira e quarta vezes. A estrutura simples da obra e sua pequena duração estão atreladas, também, ao tamanho do próprio poema de Augusto de Campos, que possui apenas quatro versos.

Fraseologicamente, não há relação aparente de antecedentes e consequentes entre as frases, sobretudo porque não há variação melódica entre uma repetição e outra, sendo as únicas alterações, que acontecem nos Compassos 9 a 11, relativas ao ritmo. $\mathrm{O}$ uso das tercinas (Figura 9) reforça a ideia jazzística sugerida pelo tratamento orquestral da construção paralela das linhas melódicas.

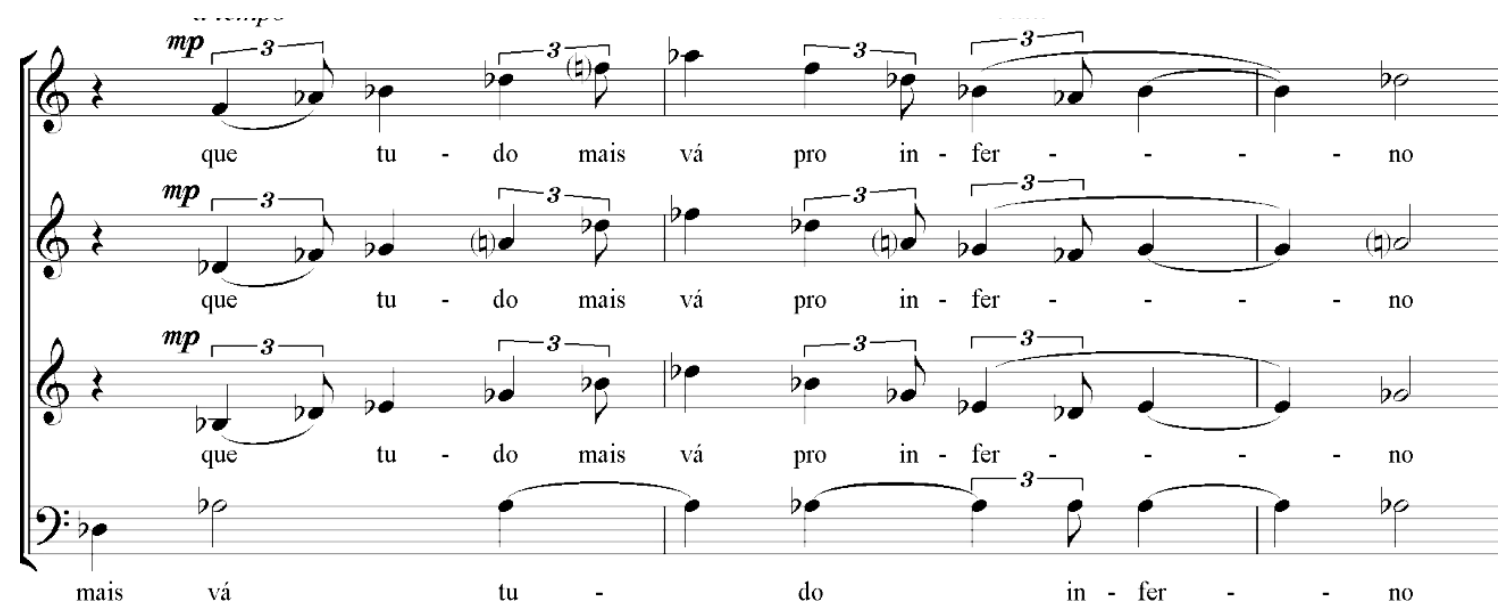

Figura 9 - Paralelismos e variação rítimica por tercinas.

\footnotetext{
${ }^{61}$ Tal prática de orquestração e construção melódica em paralelismo e homorritmia a partir de uma linha melódica principal remete à prática musical um pouco anterior à Ars Antiqua (séculos IX a XIII) conhecida como organum paralelo (CARVALHO, 2000, p. 17).
} 


\subsubsection{Relação texto-música}

A música está em sincronia com a própria duração do poema, de apenas quatro versos. A ideia irreverente contida no texto, sobretudo no quarto verso ("e que tudo mais vá pro inferno"), adotada como estilo de vida ("é o meu slogan e o do sol”), é construída, musicalmente, por Gilberto Mendes na sugestão descontraída trazida pela ideia de um Blues não muito lento, com uma sonoridade jazzística criada pelo paralelismo das linhas e, até mesmo, pelo não uso de variação, ou seja, sem se importar, de fato, se a variação é esperada ou não pelo ouvinte, sem preocupação se a repetição criará monotonia ou não.

A eternidade concentrada na ideia do nascimento diário do sol, expressa como ideia central no texto para justificar uma postura irreverente do eu lírico em relação ao mundo (BONVICINO, 2012), pode ser entendida, musicalmente, pela estaticidade da própria obra, que repete a mesma frase algumas vezes, quase sem variação. Corrobora para essa ideia de estaticidade o uso da escala pentatônica, que não possui direcionalidade (PERSICHETTI, 1978).

Ou seja, aplicando o teste de similaridade (similarity test), podemos dizer que a relação entre as mídias é coerente (coherent), pois embora as mídias tenham atributos comuns (estaticidade e duração, por exemplo), o texto tem uma narrativa que não existe na música, já que não há quase nenhuma variação entre as repetições da frase (a variação rítmica que ocorre, conforme dito, somente reforça o caráter jazzístico). Partindo da coerência, chegamos ao teste de diferença (difference test) onde, na análise, optamos por dizer que o modelo multimidiático que se aplica a esta é o da complementação (complementation), haja vista que a contrariedade (contrary) entre as mídias onde uma é essencialmente estática e a outra tem uma narrativa, um movimento adiante, complementam-se nas características que faltam uma a outra (estaticidade e narratividade), criando, assim, o sentido de irreverência.

\subsection{ANÁLISE DA OBRA “TV GRAMA I (TOMBEAU DE MALLARMÉ)”}

Esta obra reúne o curto poema de Augusto de Campos, que homenageia poeta francês Stéphane Mallarmé (1842 - 1898), com a música para coro misto à capela de Gilberto Mendes, que busca apreender e construir musicalmente a ideia tanto da 
homenagem póstuma ao poeta quanto da lamentação contida no texto, que versa sobre a preferência das pessoas pela televisão ao invés da leitura de poesia.

\subsubsection{Harmonia}

A harmonia básica da peça é construída sobre a escala pentatônica Diatônica no quinto modo (PERSICHETTI, 1978, pp. 50 e 51) sobre a base de Ré bemol (Figura 10), acrescida de notas ornamentais, como a nota Sol (Compasso 6, voz do Baixo), a nota Sol bemol e, enharmonicamente, Fá sustenido (Compasso 8, voz do Baixo), e a nota Lá (Compasso 9, voz do Baixo). Tais alterações e inserções cromáticas dizem respeito a aproximações melódicas com a escala Blues, ou seja, através do acréscimo das blue notes (Figura 11). O próprio Gilberto Mendes afirma em seu primeiro livro seu gosto pelo uso de tais ornamentações em suas melodias ${ }^{62}$.

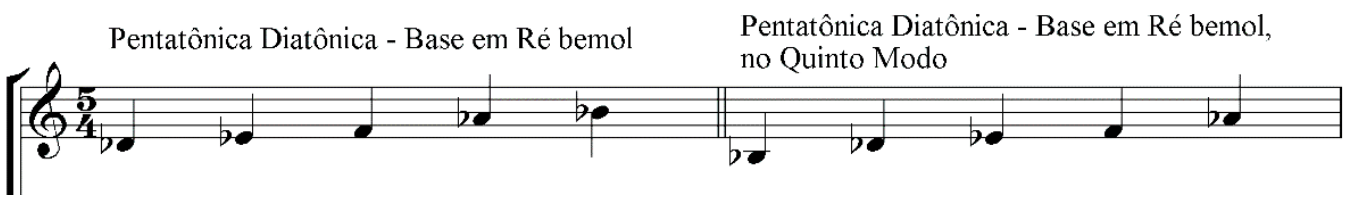

Figura 10 - Escalas que baseiam a harmonia da peça.

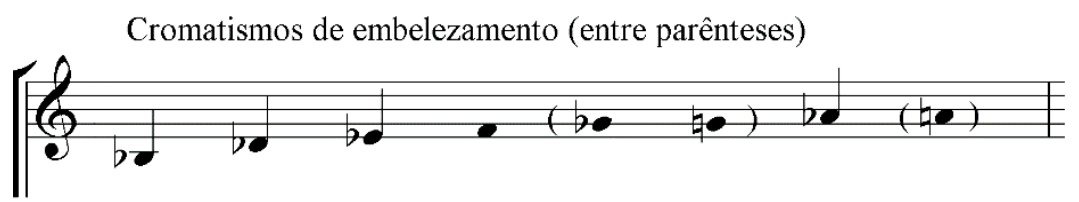

Figura 11 - Escala que baseia a peça, acrescida das blue notes.

A insistência na nota Sol inicial, na voz do Baixo, a partir do Compasso 3, vem reforçar a tensão e expectativa criadas pelo empilhamento das notas em terças menores que prepara a primeira frase da peça (Figura 12).

São dois acordes importantes, ainda, o Sol meio diminuto com sétima menor (Compasso 18) que dá lugar ao Si bemol menor com sétima menor (Compasso 18).

\footnotetext{
62 "O maestro Klaus-Dieter Wolff, grande intérprete de minhas obras corais, dizia que minha música, quando não estava às voltas com novas formas de organização sonora, microtonalismo e outras pesquisas, quando era simplesmente tonal, de comunicação fácil, tinha sempre um caráter melancólico. São as blue notes, que eu sempre gostei de colocar em minhas melodias e harmonias, as cromatizações pelos bemóis." (MENDES, 1994, p. 10)
} 
Além de encerrarem as frases, eles são resultado do empilhamento das notas da escala pentatônica Diatônica de base em Ré bemol acrescida das ornamentações, ou seja, eles sintetizam o conteúdo harmônico da peça e, também, finalizam a peça, como se desempenhassem o papel de tônica.

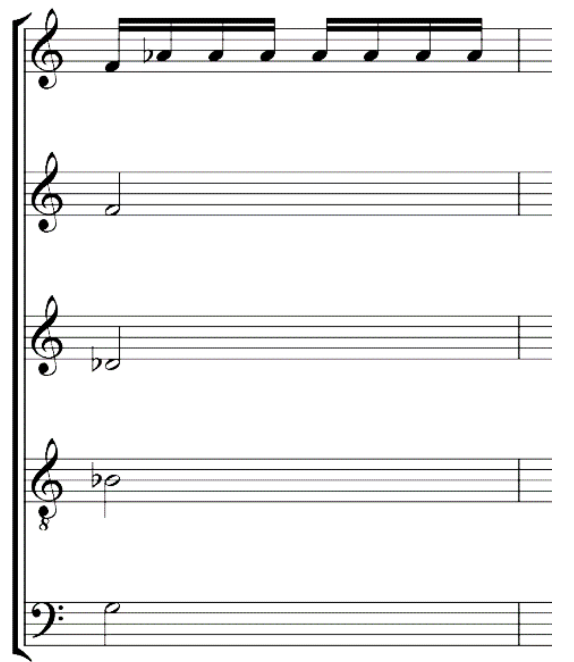

Figura 12 - Acorde que sintetiza a harmonia através do empilhamento das notas da escala.

\subsubsection{Contraponto}

A peça é construída, contrapontisticamente, de maneira homorrítimica, com a exceção do uso de alguns contrapontos entre a voz do Baixo e o restante do coro (Compasso 9, por exemplo), além do uso de homofonia (Figura 13), opondo Baixo e o restante do Coro (a partir do Compasso 14).

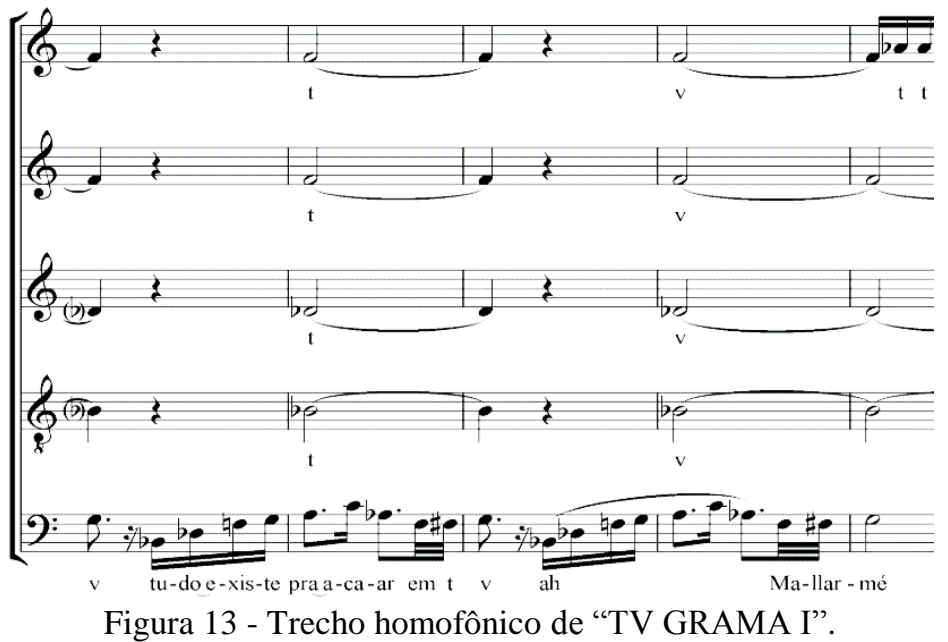

Figura 13 - Trecho homofônico de "TV GRAMA I". 
Os paralelismos insistentes nas conduções das relações das vozes de Tenor, Contralto e Sopranos nos remetem às construções de linhas por empilhamento de notas típicos das orquestrações de jazz (Figura 14), sobretudo pelo empilhamento ocorrer em terças, ou seja, antes de se tratarem de um contraponto de linhas, as vozes têm muito mais uma relação orquestral entre si.

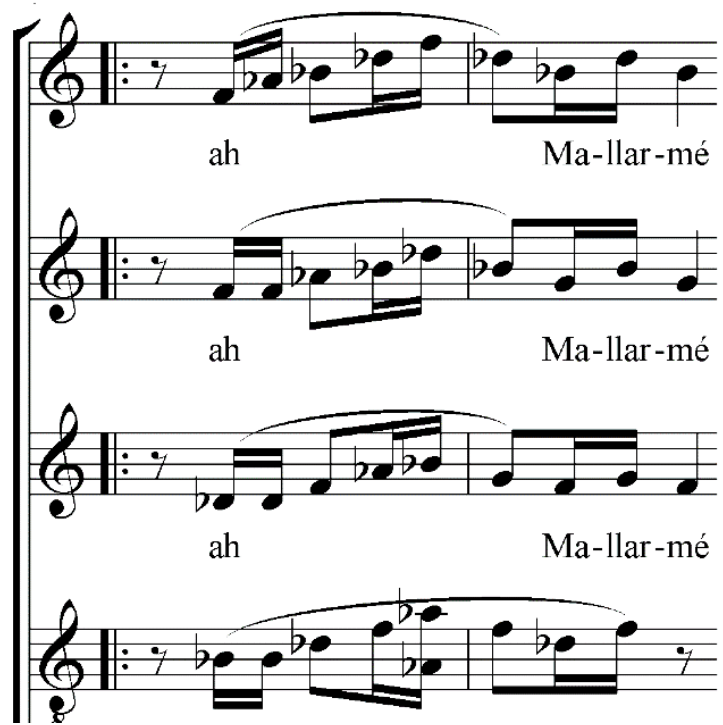

Figura 14 - Paralelismos característicos de orquestrações jazzísticas.

\subsubsection{Forma e estrutura}

Formalmente, a peça pode ser dividida em duas partes com Introdução, sendo a Introdução dos Compassos 1 a 5, onde as vozes, inicialmente recitando o texto, dão espaço para o texto cantado, criando um empilhamento com entradas defasadas das vozes (pirâmide); a parte $\mathrm{A}$, dos compassos 6 a 13, comportando as duas primeiras frases da peça; e a parte B, com as duas frases finais, contendo a linha melódica apresentada pelo Baixo em contraposição ao coro. Ou seja, apesar de ter duas partes, ambas as partes estão melodicamente relacionadas, o que caracteriza um Binário Recorrente (CAPLIN, 1998, p. 87)

Apesar da divisão binária que pode ser argumentada dadas as diferenças texturais entre os trechos que as definem (parte A, Compassos 6 a 13, e parte B, Compassos 14 ao final), sendo a obra curta e com poucas variações melódicas, ou sem a presença de uma seção realmente contrastante, afirmar que a obra é monotemática, ou seja, comporta uma única seção, também é sustentável. 
Fraseologicamente, a parte A contém um Período Paralelo ${ }^{63}$, com o antecedente dos Compassos 6 a 9, e o consequente, dos Compassos 10 a 13. Já frase contida na parte B, trata-se apenas de liquidação do material melódico apresentado anteriormente.

\subsubsection{Relação texto-música}

O uso das consoantes " $\mathrm{t}$ " e "v" na introdução, com o mesmo ritmo no coro todo, repetidos hipnoticamente, sem altura definida, e que, aos poucos, ganha alturas definidas, traz a ideia de repetição que a abreviação da palavra televisão (tv) sugere, ou seja, faz uma analogia à rotina da programação da televisão, que apresenta sempre os mesmos comerciais, programas, telejornais, etc. Reforça essa tese da hipnose televisiva o próprio texto do poema, que critica o telespectador comum por ficar em frente à televisão ao invés de ler Mallarmé ("ah, Mallarmé / a carne é triste / e ninguém te lê / tudo existe / pra acabar em tv"). Tal ideia é reforçada pela linha de Soprano que retoma a repetição hipnótica da abreviação da palavra "televisão" no final (Compasso 18), e pela própria finalização da peça, que no último Compasso repete, com um ritmo um pouco mais lento, a abreviação da palavra televisão, terminando, literalmente, como sugere o texto, em "tv".

Por sua vez, a tristeza e a melancolia que a homenagem póstuma, o "tombeau", sugere é evocada pelos cromatismos ${ }^{64}$ das linhas de Baixo (Figura 15), nas blue notes, que trazem sempre notas que não pertencem à escala, notas ornamentais, de passagem, instáveis, que baseiam a harmonia da peça, contrapondo a ideia de que o Baixo é, quase sempre, a voz da base, da fundamental, além do uso sistemático de empilhamentos de terças menores.

\footnotetext{
${ }^{63} \mathrm{O}$ Período se caracteriza, fraseologicamente, pela concatenação melódica de duas frases que estão motivicamente relacionadas entre si, e que têm uma relação de antecedente e consequente, ou seja, dependem uma da outra para exposição completa da ideia melódica. No Período Paralelo, o consequente é o mínimo contrastante possível em relação ao antecedente, quase uma repetição literal (SCHOENBERG, 1967, pp. 25-31; CAPLIN, 1998, pp. 48-58,).

${ }^{64} \mathrm{O}$ cromatismo sempre esteve ligado às ideias de lascividade ou dor e lamentação (DOURADO, 2004, p. 180). Segundo Dourado (2004, pp. 180-1) "Lamentos surgiram na ópera do período Barroco em formas de episódios para canto que precediam o desfecho da obra".
} 


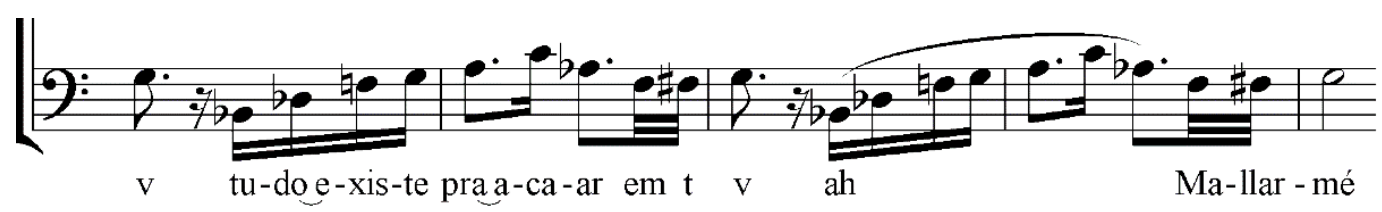

Figura 15 - Linha de Baixo cromática.

Na parte B (a partir do Compasso 14), a estaticidade dos acordes cantados por Sopranos, Contralto e Tenor que se opõem ao Baixo cria a ideia sugerida no texto, que diz que tudo acaba na televisão (Figura 16), ou seja, esse contraponto termina por vencer as variações melódicas e harmônicas sugeridas pela linha do Baixo.

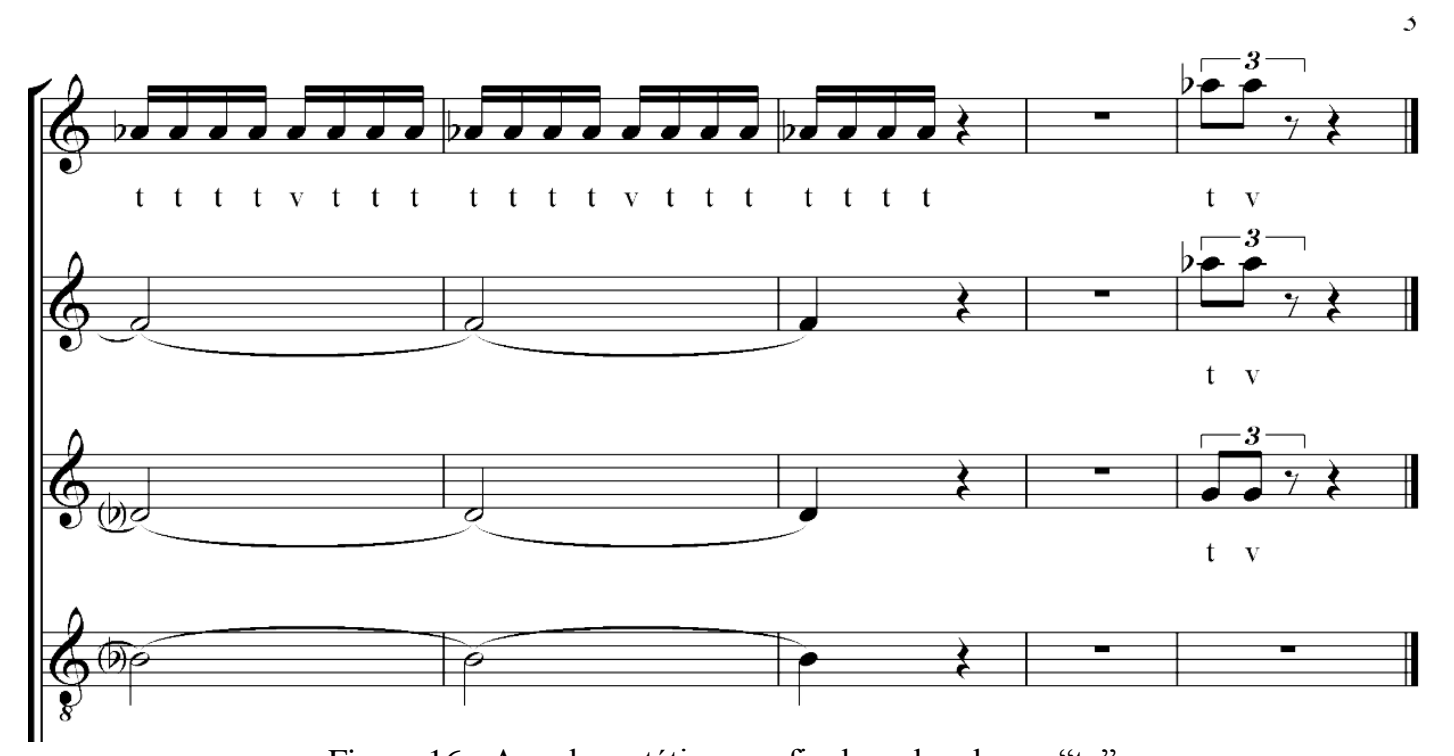

Figura 16 - Acordes estáticos no final, acabando em "tv".

Ao utilizarmos o teste de similaridade (similarity test) na Introdução da peça, é possível observar que há coerência (coherent) entre as mídias. Os sons cantados com alturas não definidas e duas consoantes, sendo uma muda "t'" e uma vocalizada "v", que são o texto, transferem os atributos da música, que tem um ritmo repetitivo, numa altura, embora não definida, quase sempre igual (reforça isso o fato de que a partitura não traz variação no posicionamento vertical das hastes, o que sugere um tom de recitação, ainda que indefinido) para o texto, que traz a ideia de tevê e todo o seu conteúdo, exibido incessantemente, seja com conteúdo educacional, informativo, de entretenimento, por exemplo, mas que está sempre exibindo algo, sem cessar, e que busca nos absorver à frente o máximo de tempo possível.

Ao passarmos para o teste de diferença (difference test), podemos observar que a contrariedade (contrary), ou seja, as informações que faltam numa mídia e noutra são complementadas (complementation) por uma e outra na criação da ideia de hipnose, com um som repetitivo de altura quase estável. 
Na parte A, o modelo de conformidade (conformance) pode ser aplicado, uma vez que a ideia de tristeza expressa no texto (“ah, Mallarmé, a carne é triste”) é consistente com a música, trazendo à tona, através dos cromatismos e intervalos menores (as blue notes são associadas aos lamentos dos negros estadunidenses), por similitude da utilização de cromatismos, tal sentimento ${ }^{65}$. Na parte B, a complementação também ocorre, mas trazendo de volta a transferência caracterizada na Introdução da peça (a contrariedade entre o texto, que tem uma narratividade, movimento, e a música, com notas longas e paradas, cantando as consoantes da palavra tevê), mas variando agora com as alturas definidas. Essa definição se deve ao desenvolvimento musical da peça, que passa das alturas definidas para indefinidas aos poucos (Compassos 3 a 5).

É interessante notar que há uma metáfora no último compasso que pode ser analisada através do teste de similaridade (similarity test), pois o texto e a música são consistentes (consistent) entre si, "dizendo" a mesma coisa. Anteriormente, o poema, no decorrer da peça, diz que tudo vem a acabar em tevê. Nesse final, literalmente a obra termina com o coro cantando "tv". Além dessa obviedade, o que contribui nessa relação são os intervalos dissonantes que finalizam a peça, em conformidade com os cromatismos anteriores das linhas de Baixo das partes A e B.

\subsection{ANÁLISE DA OBRA "O ANJO ESQUERDO DA HISTÓRIA”}

Esta obra une a poesia homônima de Haroldo de Campos e a música de Gilberto Mendes para coro misto à capela. A poesia fala sobre as disputas por justiça social no campo, preocupações políticas de sociais tanto do poeta quanto do compositor. A análise buscou lançar mão tanto sobre os processos composicionais da música quanto sobre o entrelaçamento do texto e da música na criação de significados que traduzissem as posturas políticas engajadas do compositor.

\footnotetext{
${ }^{65}$ A teoria dos afetos surgiu no Renascimento (século XVI), com os artistas da chamada Camerata Fiorentina, que teorizaram sobre os pensamentos platônicos acerca da relação texto-música, e que a própria música, através de uma melodia, harmonia ou gesto específicos, expressar um sentimento também específico, um afeto (SMITH, 1996).
} 


\subsubsection{Harmonia}

A harmonia da peça é construída sobre progressões harmônicas tonais, ou seja, sobre acordes que desempenham funções específicas dentro do contexto harmônico, gerando relações de significância e direcionalidade entre si, e modais, onde o empilhamento de terças, formando tríades, vai de encontro à construção dos acordes sobre os graus de uma escala modal, sem, no entanto, conter em si as funções harmônicas específicas requeridas em uma progressão tonal (basicamente resumidas nos movimentos harmônicos que levam à tônica).

Nessa obra, "O anjo esquerdo da história", Mendes faz uso de duas progressões básicas que podem ser analisadas tonalmente, tendo em vista que os acordes podem ser relacionados uns aos outros com função e direcionalidade específicas. Ambas as progressões encontram-se e podem ser entendidas na tonalidade de Lá menor, sobretudo por que a peça se inicia sobre esse acorde, e pelo uso de três repetições da Cadência Autêntica Perfeita (CAP) dessa tonalidade, que pode ser resumida em i - iv $-\mathrm{V}^{7}-\mathrm{i}$ (Figura 17).

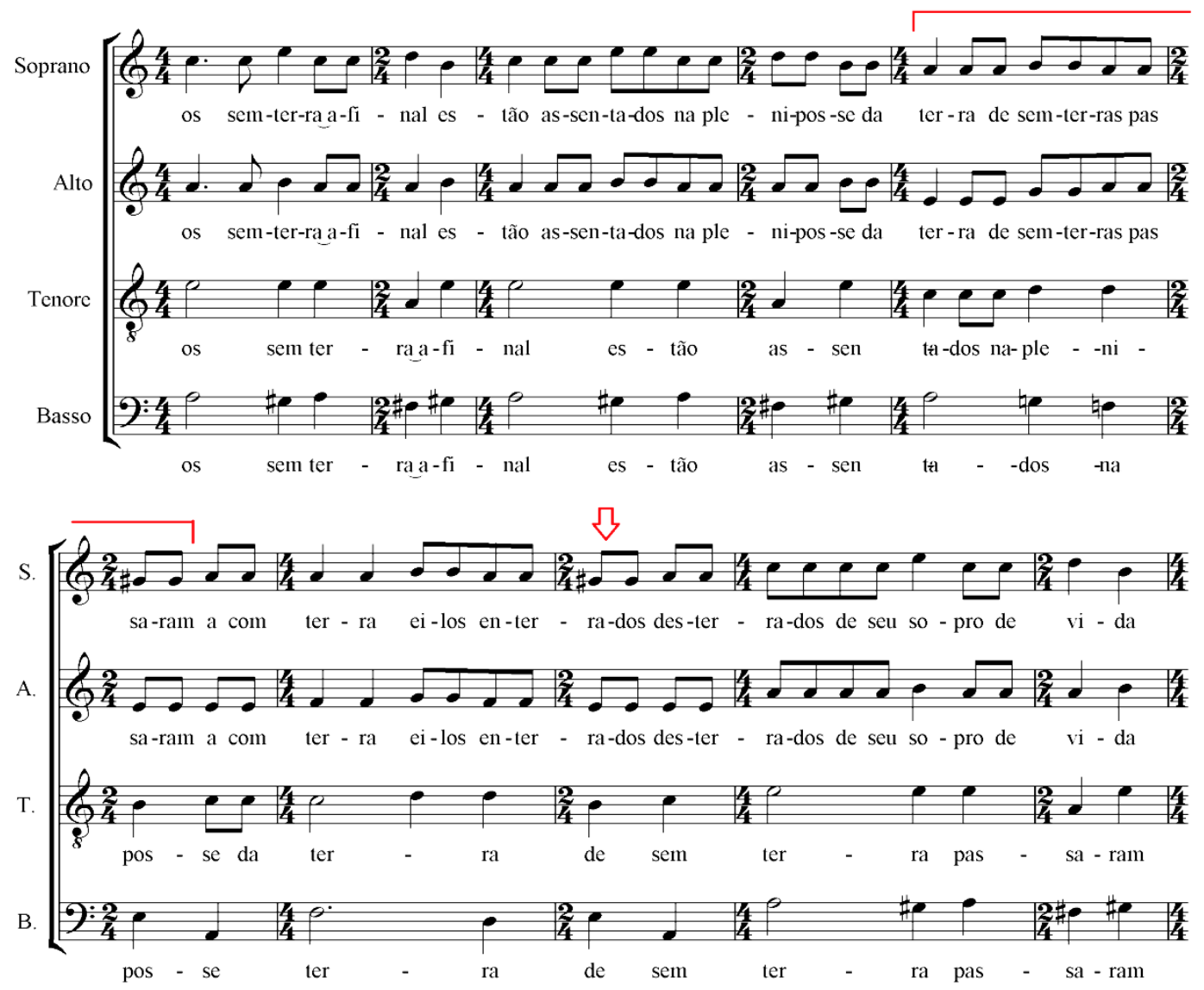

Figura 17 - Cadência Frígia e Cadência Autêntica Perfeita dentro da progressão harmônica da frase inicial. 
A primeira progressão (Compassos 1 a 8) contém não só a CAP (Compasso 8) como também uma alusão à chamada Cadência Frígia ${ }^{66}$ (Compassos 5 e 6), cuja progressão de acordes se resume em $\mathrm{i}-\mathrm{v}^{6}-\mathrm{iv}^{6}-\mathrm{V}$. Essa primeira progressão de acordes caracteriza a frase musical inicial da peça, que é repetida três vezes. Há, ainda, a presença dos acordes gerados pelo uso da escala menor melódica ${ }^{67}$ que, anteriores ao uso, no trecho, da Cadência Frígia, enriquecem cromaticamente a linha melódica do baixo, num arcadismo que relembra as progressões harmônicas e conduções de linha de baixo da música barroca.

Introduzindo a segunda progressão, o trecho dos Compassos 25 a 32 lançam mão de um pedal sobre a subdominante paralela de Lá menor, no caso, o acorde de Fá maior, que adianta, através de alteração cromática (Figura 18), a dominante sem fundamental com sétima e nona (Fá sustenido meio diminuto), ou seja, da dominante paralela (Sol maior) que, no entanto, retorna cromaticamente para o Fá maior anterior, mas agora com a sétima de dominante, adiantando, assim, a tonalidade de Si bemol maior que, entretanto, não aparece. Em seu lugar, aparece o acorde de Lá menor. Esse encadeamento dos acordes de Fá maior com sétima de dominante caminhando para Lá menor pode ser entendido tanto como uma Cadência Deceptiva, ou Cadência de Engano, quanto por uma Elipse (Figura 19), tendo em vista a omissão do acorde de Si bemol maior (ou menor) adiantado pelo Fá maior com sétima de dominante, que desempenha, em Lá menor, a função de Sexta Napolitana ${ }^{68}$, o que construiria uma Cadência Plagal ${ }^{69}$ com a variação da subdominante para a subdominante Napolitana, mas que não acontece justamente pela omissão do acorde de subdominante. Todo esse trecho harmonicamente ambíguo introduz a segunda progressão, que vai dos Compassos 33 a 40, repetida nos Compassos 41 a 47.

\footnotetext{
66 "Relação harmônica conclusiva de uma frase, (...) cuja resolução se dá por um semitom acima da nota principal" (DOURADO, 2004, p. 62). Apesar do trecho não corresponder a uma Cadência Frígia propriamente, pois tal cadência seria expressa pela progressão $i-v^{6}-i v^{6}-V$, e, no trecho, temos $i-V I I$ $-\mathrm{iv}^{6}-\mathrm{V}$, o gesto de semitom no final da cadência, aliado à linha melódica do terceiro modo eclesiástico (equivalente, posteriormente, ao modo frígio), nos permite concluir se tratar de uma clara alusão a essa cadência.

67 "Escala menor em que o sexto e o sétimo graus são maiores em direção ascendente e menores ascendentemente" (DOURADO, 2004, pp. 121-2).

68 "Acorde construído sobre a primeira inversão da subdominante, com o terceiro e sexto graus menores" (DOURADO, 2004, p. 303). No referido trecho, Gilberto Mendes faz uma passagem que remete ao uso desse acorde.

69 "Também chamada cadência do amém, devido ao seu emprego frequente nos hinos religiosos, resolve da SUBDOMINANTE para a TÔNICA" (DOURADO, 2004, p. 63).
} 


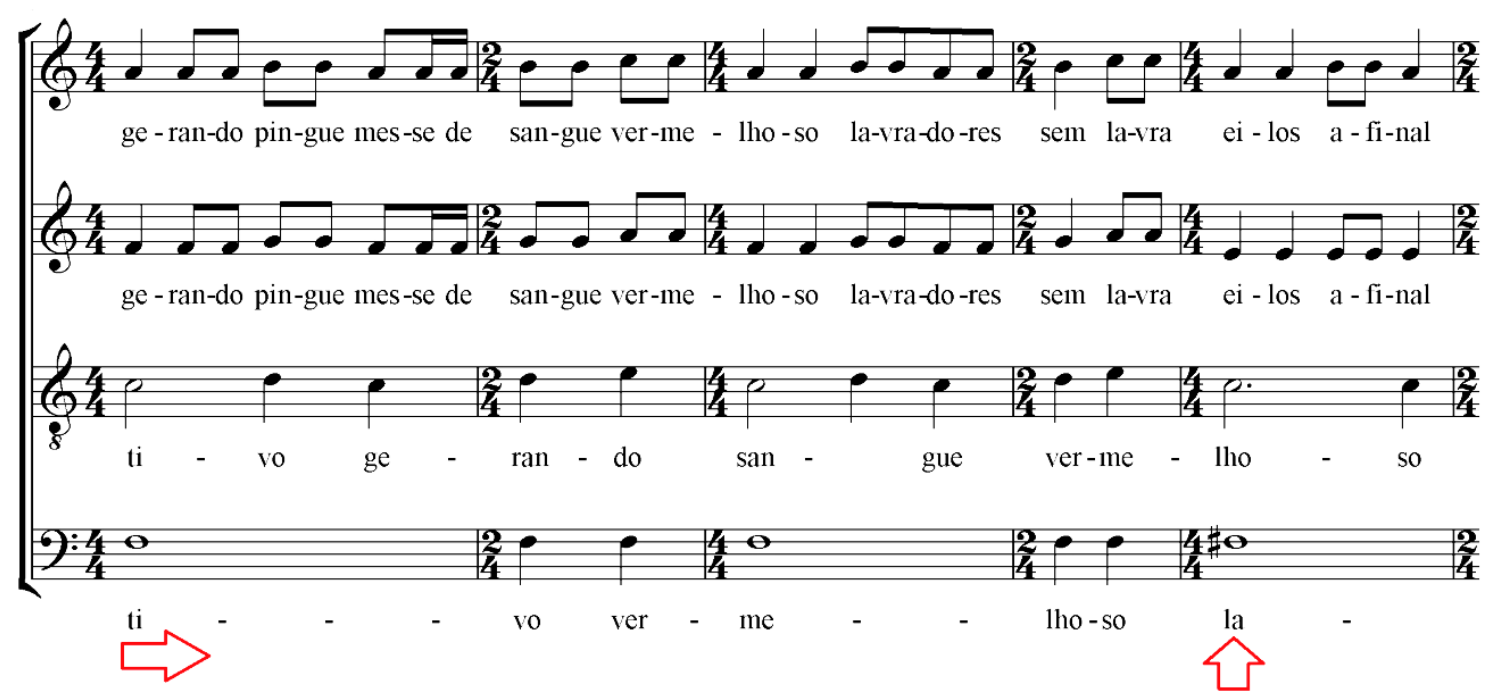

Figura 18 - Pedal na Subdominante Relativa (Fá maior) e alteração cromática.

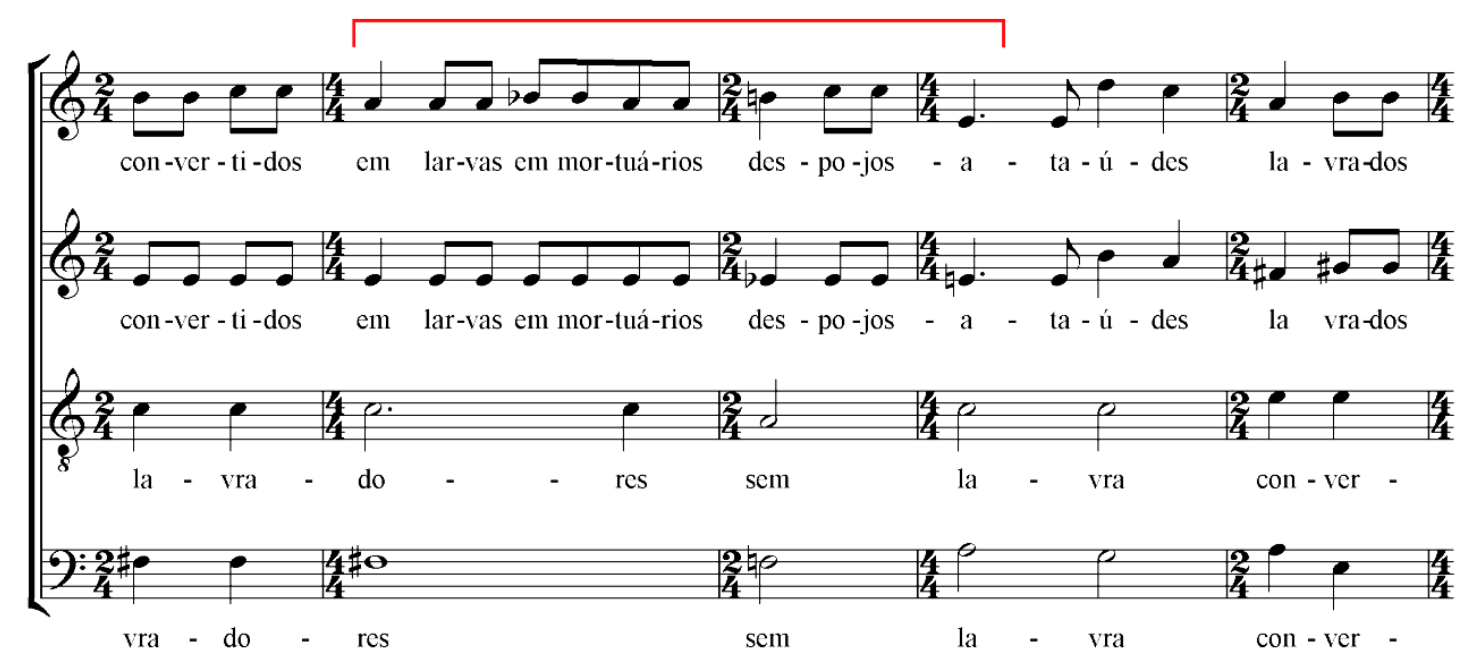

Figura 19 - Cadência Deceptiva ou possível Elipse.

A segunda progressão, embora possa ser analisada tonalmente como uma variação da primeira que foi transposta e variada para a região da tônica relativa, Dó maior, guarda muitos resquícios modais (Figura 20), sobretudo pela presença das notas Fá sustenido e Sol sustenido (voz de Contralto, Compasso 34) e pelo gesto melódico característico do modo menor melódico, que é, na melodia ascendente, a alteração cromática para cima do sexto e sétimo graus, e, na melodia descendente, o retorno das alterações às notas naturais da escala (no caso, apenas a nota Sol retorna natural e a nota Fá é omitida - Compassos 36 e 37, na voz de Soprano). Essa ambiguidade de modos gera empréstimos modais (o acorde de Ré maior com a nota de passagem na décima terceira aumentada, no Compasso 37, por exemplo) que enriquecem harmonicamente este trecho da peça, sobretudo por que aumenta o número de acordes disponíveis para a 
construção da progressão. A segunda progressão não pode ser entendida como uma modulação para a tonalidade de Dó maior porque a insistência em terminar a frase melódica sobre o acorde de dominante da tonalidade de Lá menor, o acorde de Mi maior, é muito evidente, além de ser esse o acorde que finaliza o trecho de exposição da segunda progressão, retornando ao uso do pedal sobre a subdominante de Lá menor, conforme exposto acima, que conduzirá à próxima seção da peça. É interessante notar que a finalização da frase melódica sobre a dominante remete ao uso da Semicadência (Figura 21), outra cadência muito utilizada no Período Barroco, e que reforça o arcadismo pretendido por Gilberto Mendes.
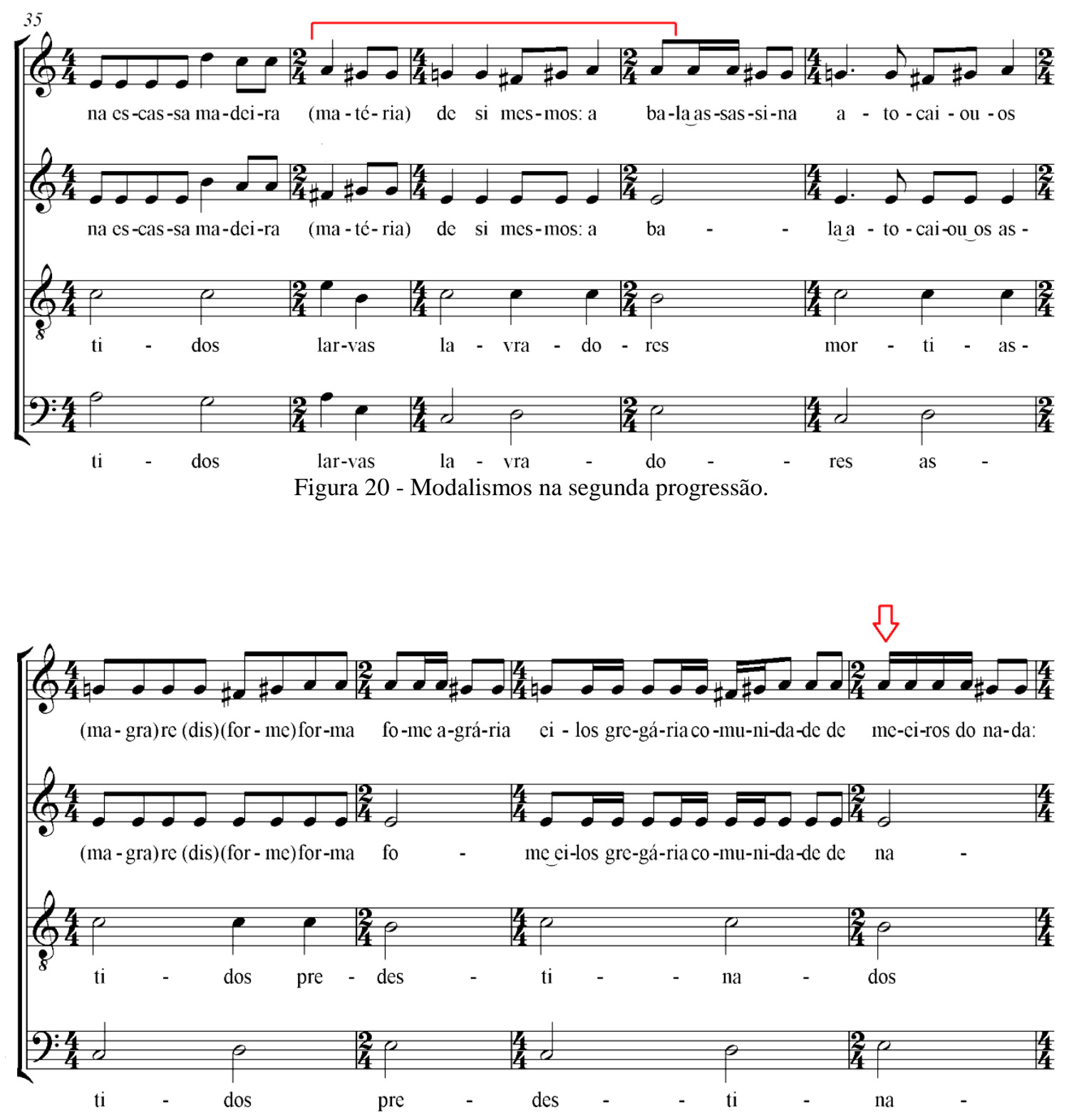

Figura 21 - Sermicadência. 
Nos compassos 58 a 62, a funcionalidade da harmonia abre espaço para a gestualidade melódica e para o contraponto. Utilizando a escala de Mi no modo Frígio ${ }^{70}$ (Figura 22), Gilberto Mendes acrescenta uma nota estranha a este modo, o Dó sustenido, que "colore" o modo, como nota de embelezamento, insistentemente cantada em uníssono por Sopranos e Contraltos, e, alternadamente, por Tenores e Baixos.

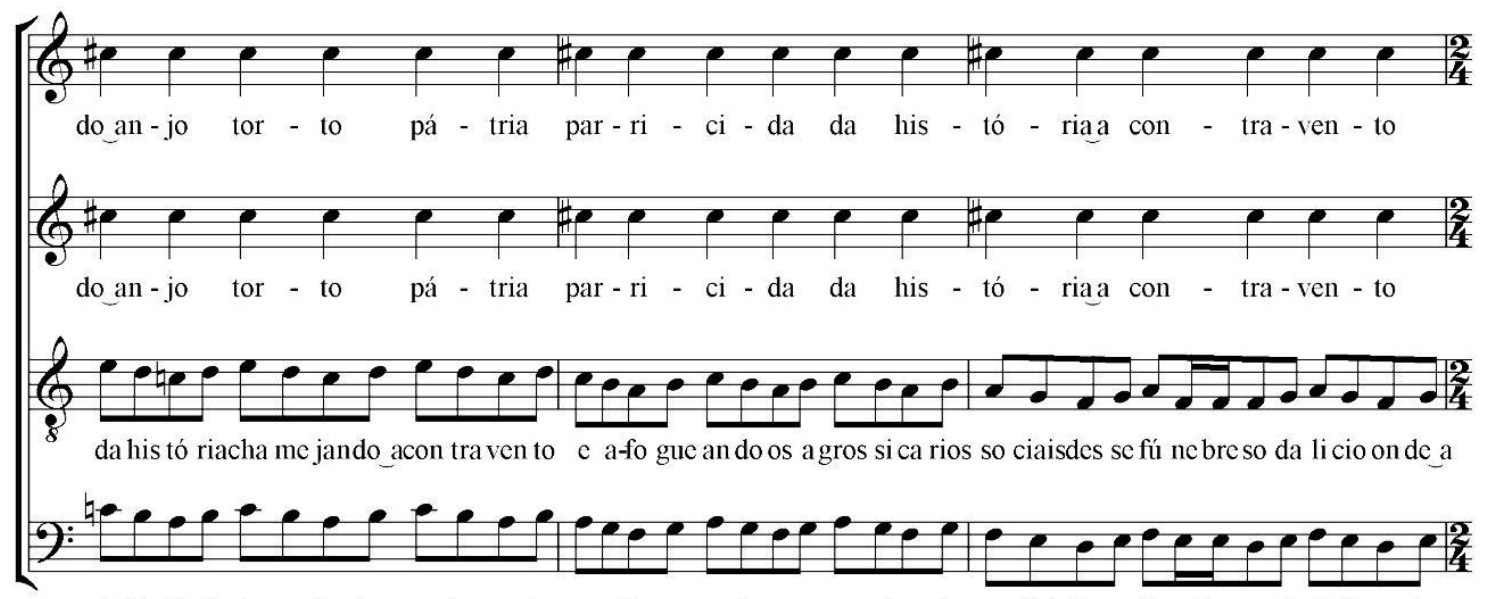

da his tó riacha me jando acon tra ven to e a-fo gue an do os a gros si ca rios so ciaisdes se fú ne bre so da li cio on de a

Figura 22 - Escala de Mi Frígio com o acréscimo da nota Dó sustenido.

No final da peça (Compassos 78 a 83), a cadência inicial é retomada com pequenas variações. A mais evidente e curiosa está no uso da Cadência Autêntica Imperfeita $(\mathrm{CAI})^{71}$ ao invés do uso da CAP para a finalização da obra (Figura 23). Apesar da afirmação harmônica não muito incisiva evocada pelo uso da CAI, as três repetições da cadência contrabalanceiam tal fraqueza harmônica ${ }^{72}$.

\footnotetext{
70 “Terceiro MODO AUTÊNTICO eclesiástico, construído sobre a nota mi” (DOURADO, 2004, p. 140).

${ }^{71}$ Segundo Caplin, uma cadência onde o movimento melódico na voz do soprano se resolve na terça, quase nunca na quinta, ao invés de se resolver com o movimento de sensível e na tônica (CAPLIN, 1998, p. 254).

${ }^{72}$ CAPLIN (1998, p. 51) define que a Cadência Autêntica Perfeita, ao contrário da Cadência Autêntica Imperfeita, tem um poder de resolução e afirmação harmônica maior, sendo, portanto, harmonicamente mais forte que a segunda.
} 


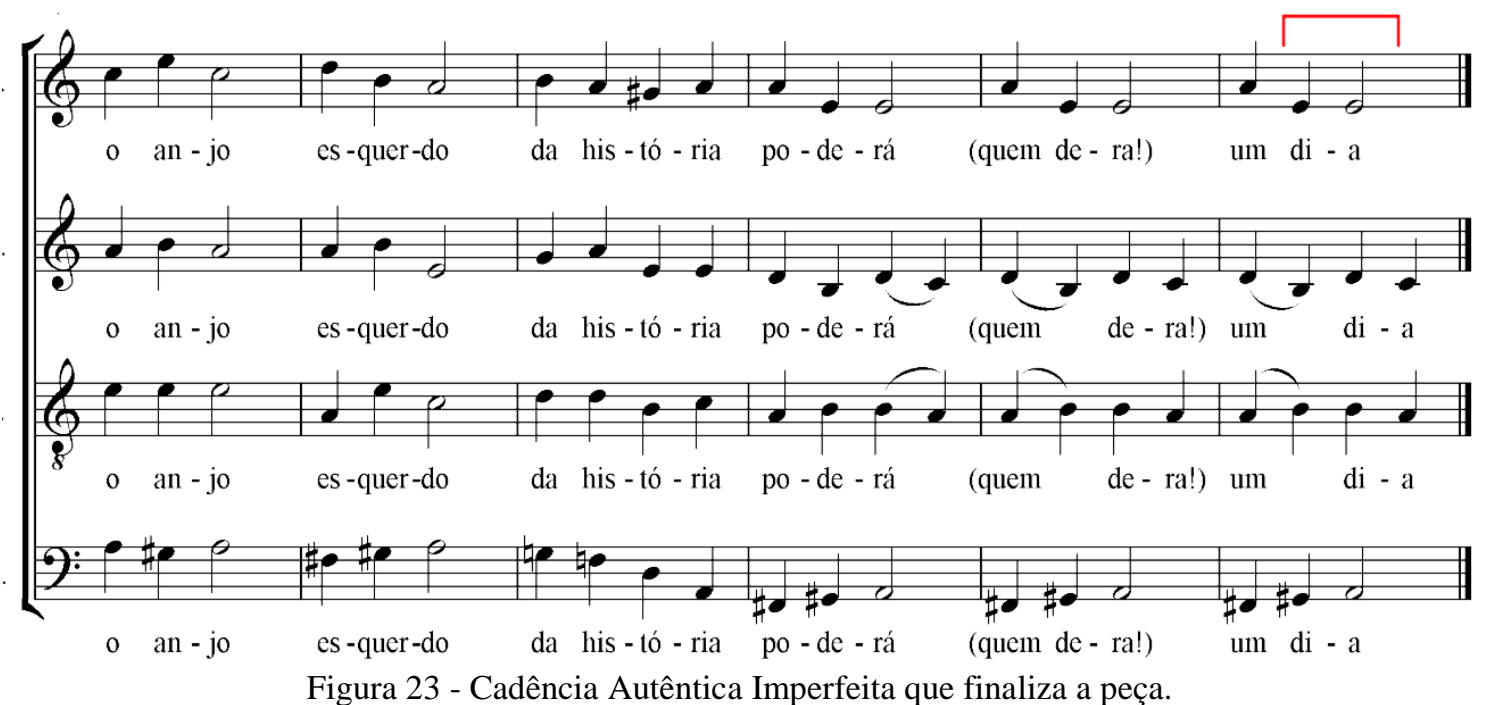

\subsubsection{Contraponto}

À moda dos corais de Johann Sebastian Bach (1685 - 1750), Gilberto Mendes utiliza-se de um estilo de escrita contrapontística homorrítmica, com preferência pelo contraponto de primeira espécie ${ }^{73}$. Mesmo a parte não cantada, mas recitada, é homorrítimica, bem como a Codetta. Já o trecho de transição caracteriza-se pelo uso do movimento oblíquo das vozes, sobretudo contrapondo os conjuntos de vozes masculinas e femininas, com o uso de duas notas contra uma, típico do contraponto de segunda espécie.

A preferência pelo contraponto homorrítmico, com o privilégio da primeira espécie favorece a inteligibilidade do texto, pois limita o número de melismas sobre uma mesma sílaba. Tal preferência pode ser observada em música sacra como os hinos, onde o conteúdo do texto deve ser inteligível ao público. O próprio Bach e tantos outros compositores, como Heinrich Schutz (1585 - 1672) e Michael Praetorius (1571 - 1621), ao escreverem peças onde o texto tinha tanta importância quanto a música, preferiram a escrita homorrítmica com poucos melismas sobre cada sílaba, privilegiando, assim, a inteligibilidade daquilo que está sendo cantado pelo coro ${ }^{74}$.

${ }^{73} \mathrm{O}$ contraponto de primeira espécie, cujo nome se atribui a Johann Joseph Fux (1660 - 1741), versa sobre a criação de um contraponto de nota contra nota sobre um cantus firmus já existente, ou seja, para cada nota da melodia, uma outra de igual duração deve contrapô-la, segundo regras de condução de vozes pré-estabelecidas (TRAGTENBERG, 1994, p. 21).

${ }^{74}$ Segundo Ouvrard (1997, p. 283), Palestrina enfrentou problemas com o clero a seu tempo porque os clérigos argumentavam que a polifonia da qual ele se utilizava em suas músicas sacras distorcia o sentido do texto. Os corais e hinos de origem luterana, no entanto, primavam justamente pela inteligibilidade do 


\subsubsection{Forma e estrutura}

Diferentemente do poema disposto junto aos manuscritos (uma versão digitada, com assinatura do próprio poeta, Haroldo de Campos), que está dividido em três estrofes, a divisão da forma da peça não coincide com a forma do poema.

Estruturalmente, podemos desenvolver o seguinte esquema:

$\begin{array}{lccccc}\text { Seções } & \text { Seção A } & - & \text { Seção B } & - & \text { Codetta } \\ \text { Frases } & a-a^{\prime}-a^{\prime \prime}-b-c-c^{\prime}-b^{\prime \prime} & - & d-\text { parte recitada } & - & a "\end{array}$

A partir desse esquema, podemos definir que a peça é organizada estruturalmente num Binário Seccional ${ }^{75}$, cuja seção A contém: a frase inicial repetida três vezes (a), que encerra em si a progressão harmônica tonal, em Lá menor; o trecho de transição (b), que comporta o pedal sobre a subdominante relativa de Lá menor, alterado cromaticamente e encerrado na mesma subdominante; e a segunda progressão (c). A seção B contém a parte modal da peça (d) e a parte recitada. A Codetta retoma a progressão da primeira frase da peça (Compassos 1 a 8) variada.

Fraseologicamente, a primeira frase (a) - Compassos 1 a 8 , repetida por mais três vezes, até o Compasso 24 - é um Período Contrastante, cujo antecedente está nos Compassos 1 a 4 e o consequente, nos Compassos 5 a 8. Apesar do contraste melódico, a similaridade dos gestos melódicos, sobretudo pela presença do movimento melódico de sensível (Compassos 2 e 3, e Compasso 6), não caracteriza sobremaneira um contraste pronunciado. Na segunda frase (b), a da transição (Compassos 25 a 32, e repetida nos Compassos 49 a 56), notamos um Período Paralelo, com o antecedente nos Compassos 25 a 28, e o consequente nos Compassos 29 a 32, tendo em vista poucas variações melódicas, ficando as variações quase que exclusivamente ligadas à harmonia. Na terceira frase (c), a da segunda progressão, que vai dos Compassos 33 a 48, temos outro Período Paralelo, ou seja, a frase é quase que repetida integralmente, a não ser por pequenas variações rítmicas exigidas para o encaixe do texto que é diferente no antecedente (Compassos 33 a 40) e no Consequente (Compassos 41 a 48). Na parte

texto, garantido pelo contraponto de primeira espécie, além de melodias simples (VIGNAL, 1997, p. 289).

${ }_{75}$ O Binário Seccional consiste numa forma bipartida onde a segunda parte não guarda relação motívica e temática com a primeira (CAPLIN, 1998, p. 49). 
modal (Compassos 57 a 62), a frase possui características de Sentença ${ }^{76}$, com gesto inicial e repetição nos Compassos 57 e 58, e fragmentação nos Compassos 59 a 62 . É interessante notar que não há cadência, o que seria característico de uma Sentença, e que a frase termina na parte recitada, ou seja, não se trata propriamente de uma Sentença, mas possui características desse tipo de frase. A parte recitada tem um antecedente apresentado pelos naipes femininos (Compassos 63 a 66), um consequente apresentado pelos naipes masculinos (Compassos 66 a 70), e um tipo de cadência que reúne todos os naipes num tutti. A Codetta possui uma frase singular, onde não há antecedentes ou consequentes, tampouco fragmentações ou liquidações temáticas, mas apenas a variação simples da frase inicial da obra.

\subsubsection{Relação texto-música}

O mote do poema é a reforma agrária e a luta no campo. Gilberto Mendes lança mão da tonalidade menor e, sobretudo, da Cadência Frígia, historicamente associada à dor e ao sofrimento, para reproduzir a dramaticidade da luta diária enfrentada pelos trabalhadores sem-terra no campo. Além disso, a incerteza da vida diária daqueles que vivem a luta pela reforma agrária é reforçada pelas inúmeras ambiguidades, quer seja das Cadências Deceptivas, quer pelo uso de muitos empréstimos modais e cromatismos, sem falar na inclusão de notas estranhas à escala, mas que não caracterizam notas de passagem, como nos Compassos 57 a 62, por exemplo. Ou seja, aplicando o teste de similaridade (similarity test), observamos a consistência (consistent) entre as mídias, pois aquilo que está verbalizado no texto também já existe na música, o que gera um modelo de conformidade (conformance) multimidiática.

$\mathrm{Na}$ Codetta, a repetição da Cadência Autêntica Imperfeita, associada às palavras, que trazem a ideia da incerteza do cumprimento da promessa constitucional que versa sobre a função social da terra ${ }^{77}$ e da justiça no campo contidas no texto da poesia cantada pelo coro em "o anjo esquerdo da história/ poderá / (quem dera!) um dia" cria a ambiência sonora incerta, não afirmativa, abrindo a dúvida para o ouvinte. Isso também é reforçado pelos retardos cantados nas vozes de Contralto e Tenor (retardos de $6-4$, e

\footnotetext{
${ }^{76}$ Segundo Caplin, a Sentença é um tipo de tema bem simples, composto, basicamente, de frases de apresentação e continuação, e cadência (CAPLIN, 1998, p. 257).

77 BRASIL. Constituição (1988). Artigo 5º inciso XXIII. Brasília, 5 out. 1988. Disponível em: <http://www.planalto.gov.br/ccivil_03/constituicao/constituicao.htm>. Acesso em: 30 jun. 2014.
} 
5 - 3) que trazem a ideia de hesitação na resolução das dissonâncias, conferindo mais dramaticidade ao texto. Além disso, a opção que Gilberto Mendes faz do não uso da Cadência Piccarda ${ }^{78}$, muito comum nos corais barrocos, sobretudo no referido compositor alemão, Bach, que, através da resolução da frase final de uma música em tonalidade menor num acorde maior (Lá maior, no caso), traria a sensação não de desesperança e hesitação que a indissolução dos quase perenes problemas agrários brasileiros evocados no texto de Haroldo de Campos, mas, sim, de alento, de que algo estaria, de fato, mudando. No entanto, em se tratando mais de um desejo do eu lírico que de um fato concreto e narrado, Mendes opta por manter o clima de incerteza e desesperança que os retardos associados à resolução na tônica - Lá menor proporcionam. Sendo assim, a conformidade (conformance) é o modelo multimidiático mais adequado para descrever essa interação entre as mídias, pois texto e música possuem já em si as mesmas características que trazem esse sentido de incerteza e desesperança.

Nos Compassos 63 a 76, onde há um recitativo, o modelo é diferente. A afirmação do ritmo composto por uma colcheia, e seis semicolcheias, agrupados em dois tempos de um compasso binário, associada ao texto que roga uma solução fatídica e justa para os problemas do campo, onde o "anjo esquerdo da história" vem julgar e por fim a tais querelas, mostra existir coerência (coherent) entre as mídias o que, no teste de diferença (difference test) pode ser lido como contrariedade (contrary), pois o sentido afirmativo do ritmo repetido, embora não vá de encontro à narrativa do texto, ocupa o espaço deixado pelo poema para, em conjunção com esse, criar a ideia de previsão, onde o julgamento dos opressores será inevitável. Portanto, há um modelo de complementação (complementation) entre as mídias na criação desse sentido.

Vale lembrar, ainda, que próprio compositor afirmou inúmeras vezes seu engajamento político mais ligado ao Socialismo e ao Comunismo ${ }^{79}$, cujas bases brasileiras ${ }^{80}$ remontam, também, à luta por justiça social no campo, sendo tais posturas

\footnotetext{
${ }^{78}$ A Cadência Piccarda, orginalmente chamada "Tercie de Picardie" diz respeito à finalização de uma obra musical (ou trecho de obra) num acorde maior, sendo a mesma escrita em tonalidade menor (por exemplo, uma música cuja tonalidade seja Lá menor, mas que, ao invés de o último acorde, de tônica, ser menor, é, na verdade, uma Lá maior). O nome em francês foi dado por Jean-Jacques Russeau (17121778) em seu "Dictionnaire de musique" (1767) (RUSHTON, Julian. Tercie de Picardie. In: Oxford Music Online. Página da Internet. [S.l.], Sem data. Disponível em: $<$ http://www.oxfordmusiconline.com/subscriber/article/grove/music/27946>. Acesso em 30 de jun. 2014).

79 "Da minha parte, sempre fui socialista (...)" (MENDES, 1994, p. 175).

${ }^{80}$ O historiador Boris Fausto afirma que a ideologia do Partido Comunista Brasileiro, fundado em 1922 (ano de nascimento de Gilberto Mendes), considerava, além das pautas internacionais caras aos
} 
e preocupações do compositor evidentes aqui nesta obra analisada que, claramente, busca refletir musicalmente tais posturas.

\subsection{ANÁLISE DA OBRA "UMA VEZ, UMA VALA"}

Gilberto Mendes busca referências rítmicas no próprio texto e em outra obra sua, o "Motet em Ré menor - Beba Coca-cola", para a criação musical desta peça coral à capela, que tem a poesia de Augusto de Campos como obra interseccional na criação das expressões multimidiáticas nela contidas.

\subsubsection{Harmonia}

O movimento harmônico quase que coincide com a mudança de um Compasso para o outro (Compassos 1 a 8, por exemplo), e, por vezes, se estende a mais de um Compasso (Compassos 9 e 10, por exemplo). A falta de movimentação harmônica tira proveito dos timbres que as pequenas movimentações melódicas internas no coro, ocasionada pelas inversões sucessivas do acorde, sem, contudo, mudar-se tal acorde.

Através de deslizamento cromático, Gilberto Mendes passa de um acorde Si Menor para o seu correspondente homônimo Si bemol Menor e segue através de uma relação de terça menor (PERSICHETTI, p. 68), ou seja, sempre alternando entre Si bemol Menor e Ré bemol Maior. A resolução se dá já na Casa 2 (Compasso 14), com o uso da escala de Mi frígio, que se direciona para a próxima região harmônica, onde um acorde sétima de dominante ${ }^{81}$, sem a fundamental e com a nona acrescentada, composto pelas notas Fá sustenido, Ré sustenido, Lá natural e Dó sustenido, baseia todo o trecho até a retomada da frase inicial, mas já modificada (Compasso 23). A frase inicial modificada apresenta três acordes diferentes, sendo um Dó menor com sétima maior no baixo, um Si bemol maior com sétima menor, e terça no baixo, e Si diminuto que,

movimentos esquerdistas da época, a questão da reforma agrária como ponto chave no estabelecimento da justiça social e de um poder proletário (FAUSTO, 2012, p. 260,). Ademais, o historiador destaca as reivindicações dos colonos imigrantes, que trabalhavam nas lavouras de café do final do século XIX, e o surgimento da classe operária nos centros urbanos, durante o mesmo período, como fundamentais na organização dos movimentos sociais de esquerda no Brasil (FAUSTO, 2012, p. 253).

81 "Acorde que consiste em uma tríade construída sobre o quinto grau de uma escala, acrescida de uma sétima contada a partir de sua fundamental" (DOURADO, 2004, p. 302). No caso, o acorde tem sua fundamental omitida e, além disso, ainda conta com a nona contada a partir dessa mesma fundamental. 
melodicamente, resolve na nota Dó do soprano (Compassos 24 e 25 - movimento de sensível), cujo apelo resolutivo é desfeito com a entrada do acorde de Ré bemol maior que segue. A alternância entre os acordes meio diminutos de Mi e Ré sustentam a harmonia do trecho até o Compasso 31, onde o uso da escala de Lá eólio com o acréscimo de Dó sustenido denota a ambiguidade maior/menor que culmina nos clusters do Compasso 34. Segue, então, a mistura de sons cantados (clusters) e falados, com uma linha melódica de intervalos de segunda, alternando as notas Fá sustenido e Mi na voz do Soprano, que se resolve na retomada do mote inicial da peça, alterado.

\subsubsection{Contraponto}

Contrapontisticamente, a obra está baseada em movimentos que aludem a uma fuga, com a entrada das vozes - que seriam como se fossem os sujeitos de uma fuga sempre defasada em relação à anterior. No entanto, as entradas defasadas por si só não são suficientes para conferir movimento contrapontístico, pois a movimentação das linhas não acontece de maneira independente, ou seja, as entradas defasadas funcionam muito mais como a construção de uma pirâmide, ora do grave para o agudo (Compasso 15), ora do agudo para o grave (Compasso 23) e, algumas vezes, em ordens intercaladas nos registros (Compasso 25), que como entradas de uma fuga, ou stretto de fuga.

O contraste no uso de diferentes recursos contrapontísticos fica por conta da oposição, durante toda a peça, entre os trechos homorrítmicos e aqueles em que as entradas das vozes estão em stretto. Não há na peça nenhum ponto onde exista, de fato, a simultaneidade melódica pressuposta por uma fuga, ao passo que os exemplos de melodia acompanhada, como entre os Compassos 26 e 29, e mesmo entre os Compassos 19 e 22, demonstra que, muito mais que o trabalho textural de contraposição de melodias, o compositor buscou jogar com os coloridos resultantes das sobreposições das notas sem movimento, como pedais (Compassos 9 e 10, por exemplo). Reforça a tese do trabalho com texturas de timbre o uso contraposto de voz falada e voz cantada, onde o texto é recitado, com um ritmo escrito, simultaneamente ao texto cantado, criando, aí, sim, um contraponto não só de linhas, mas de timbres também.

O contraponto que permeia a obra é de primeira espécie, a quatro vozes, com entradas em fugato no começo de cada trecho (início, Compassos 14, 17, 23, 38). Em 
alguns trechos, temos o uso de homofonia (melodia acompanhada), como no Compasso 26.

\subsubsection{Forma e estrutura}

Os intervalos de terça, tanto maiores quanto menores, desempenham uma função estruturante na obra, uma vez que são sempre os empilhamentos desses intervalos que dão início à retomada do gesto inicial da peça em seu desenrolar musical. Eles têm importância também nos trechos homorrítmicos, como nos Compassos 18 a 22, onde relações de terça entre as vozes e sua inversão (sexta), são fundamentais para a criação das linhas; no trecho dos Compassos 31 a 33 (Figura 24), onde existe uma ambiguidade na terça maior Dó - Mi entre Tenor e Contralto, que não é correspondida pela inversão do intervalo, a sexta maior Mi - Dó sustenido, pois a inversão de uma terça maior seria uma sexta menor. É interessante notar que esse recurso harmônico (além disso, são as mesmas notas) foi usado também na obra "o anjo esquerdo da história”, mas de maneira diferente. Lá, a relação é modal, pois a escala de Mi frígio é evidente na peça toda, e o Dó sustenido desempenha um papel ornamental, ou mesmo de criação de tensão no contexto harmônico; aqui, tais relações surgem dos intervalos de terça.

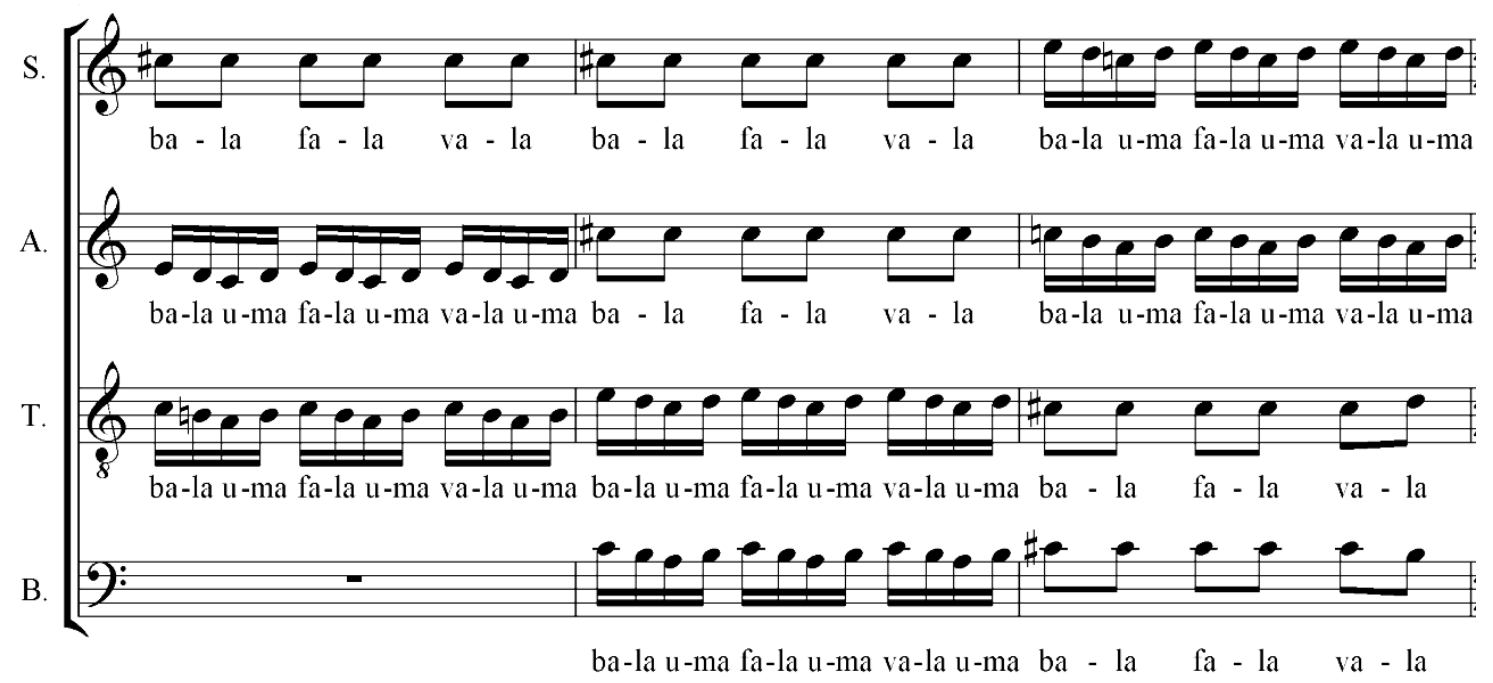

Figura 24 - Relações de terças e sextas - Compassos 31 a 33.

Os Compassos de 1 a 13 contêm quase todo o material musical da peça (essa primeira frase não contém os clusters que aparecerão mais adiante, no Compasso 34, mas já têm as alturas indefinidas presentes no recitativo do Compasso 13), começando 
pelo empilhamento de intervalos de terças maiores e menores a partir da voz de Soprano, até a homorritmia cadencial da frase a partir do terceiro tempo do Compasso 8. Sendo assim, se dividirmos essa frase inicial em duas partes, sendo a primeira A dos Compassos 1 a 7, e a segunda, B, dos Compassos 8 a 13 é possível definir a estrutura do restante da obra da seguinte forma:

- Compassos 15 a 17: elaboração de A; temos o empilhamento de terças repetido duas vezes, mas com alturas distintas das iniciais; o acorde de sétima, no caso um acorde menor com sétima maior, está presente;

- Compassos 18 a 22: elaboração de B; temos a homorritmia que opõe o coro cantando em terças ${ }^{82}$ empilhadas a voz de Soprano, também com alturas alteradas em relação à frase inicial - as vozes têm agora um movimento melódico interno e diatônico;

- Compassos 23 a 26: elaboração de A; desta vez, o gesto de empilhamento da frase inicial está mais parecido, sobretudo porque se inicia com a voz de Soprano, a diferença é que vai do naipe mais agudo para o mais grave. Além disso, as alturas são outras, no entanto o acorde menor com sétima só se faz presente no Compasso 23 e, no Compasso 25, que também tem o gesto inicial de A não forma esse acorde; a relação entre as entradas das vozes está estabelecida sobre os intervalos de sétima maior - Dó Ré bemol (Soprano e Tenor) e Mi - Fá (Contralto e Baixo);

- Compassos 26 a 30: elaboração de B; o intervalo de trítono entre Baixo e Tenor é incorporado à harmonia do coro que acompanha a voz de Soprano, embora as terças estejam presentes, além do intervalo de segunda maior Lá bemol - Si bemol (Compasso 30), que pode ser visto como inversão dos intervalos de sétima do trecho anterior com uma alteração cromática de meio tom pra cima, produzindo, assim, a segunda maior.

Os Compassos 31 a 33 apresentam um elemento novo melodicamente, opondo, num contraponto de movimento oblíquo, a nota Dó sustenido às vozes cantando em semicolcheia intervalos de terça.

Os clusters e recitativos vêm remeter ao final de $\mathrm{B}$, onde o recitativo sobre o ritmo inicial de A vem concluir a cadência da frase inicial. Esse trecho dos clusters pode ser visto como um ápice na construção da narrativa dramática da peça, pois além de remeter à finalização da primeira frase, usa notas muito agudas no Soprano, gerando tensão através da proximidade de intervalos microtonais. Essa tensão é quebrada, em seguida, pela retomada do gesto inicial de $\mathrm{A}$ - o acorde menor com sétima está presente.

\footnotetext{
${ }^{82}$ Sempre que não especificamos se são terças maiores ou menores nos referimos à coexistência de ambas no trecho em questão.
} 
No Compasso 42, o compositor retoma a ideia de B, substituindo o trítono entre Baixo e Tenor do trecho anterior que reapresenta B por um intervalo de quinta justa. Isso nos mostra uma expansão do tamanho do intervalo, começando com uma terça, passando por uma quarta/quarta aumentada, visto que o trítono é um intervalo de quarta, e chegando a uma quinta justa. Subitamente, no Compasso 46, o ritmo inicial da peça, com o mesmo texto, é cantado homorritmicamente por todo o coro, e segue um retorno à ideia homofônica de $\mathrm{B}$, que é repetida até a encenação do teatro musical, no Compasso 56. A Codetta, nos Compassos 58 e 59, encerra a obra com a homofonia de $\mathrm{B}$, os intervalos empilhados, mas reproduzindo o acorde menor com sétima (no caso, sétima no Baixo), como se não só encerrasse a obra, mas a resumisse.

\subsubsection{Relação texto-música}

Segundo o compositor $^{83}$, o ritmo falado do texto o remete a outra obra sua, o Motet em Ré menor "Beba Coca-Cola”, cujo início em fugato também é característico. Sobre o texto, Mendes firma ser a criação de um drama através de imagens soltas, remetidas pelos substantivos enumerados, acompanhados dos artigos indefinidos.

O uso de acordes menores com sétima menor está no cerne da obra, engendrando em si a ambiguidade de possuir em si mesmo a força das tônicas tanto do modo maior quanto do modo menor em um único acorde (Exemplo: Lá menor com sétima menor contém em si as notas do acorde de Dó maior, que é o acorde de tônica da escala relativa de Lá menor).

Os caminhos harmônicos, sempre através de deslizamentos cromáticos ou modulações por notas comuns, especialmente através da mediante ou pela simples transposição de uma frase uma segunda maior ou menor abaixo ou acima transparece a não direcionalidade da harmonia, de modo que existe sempre um movimento contínuo. Se pensarmos no teste de similaridade (similarity test), veremos, então, que existe consistência (consistent) entre a música e o texto, pois o texto se pretende a criar uma narrativa dramática que é apoiada pela música que não atinge ponto algum, não tem cadências conclusivas. A dissolução das alturas definidas em clusters e recitativos com ritmos definidos (Compasso 34) colabora para a criação do drama na medida em que funciona como ponto culminante, onde, no trecho anterior (Compassos 15 a 33), que

\footnotetext{
${ }^{83}$ Vídeo acessado em 25 de novembro de 2013, às 13:45 h. Disponível em: http://youtu.be/ebtTzobFTpw
} 
leva até esse ponto, o ritmo se intensifica, o contraponto também, transferindo tais atributos à narrativa descrita pelas palavras. Portanto, o melhor modelo multimidiático que descreve a peça é o de conformance (conformidade).

A repetição das palavras do texto, associada a uma intensificação rítmica que culmina em clusters microtonais (Compassos 29 a 34), cria musicalmente o drama descrito pelo compositor, e que serve de trilha sonora para a encenação do teatro musical que o coro deve realizar a partir do Compasso 48.

A encenação descrita na partitura pede que o coro faça um gesto com as mãos que imite um revólver, e que o coro reproduza o efeito visual do rebote que é produzido pelo disparo de uma arma de fogo real, condizente com o som percussivo produzido pela sílaba "ba" da palavra "bala" do Compasso 52, direcionando-se à plateia, como se um tiro fosse disparado contra esta. A ideia de morte, ou da tragédia da violência advindas do ato de atirar é sugerida pela Codetta, onde é cantado, em repetição, até o volume alcançar o inaudível, as palavras "fala", "bala" e "vala".

O teatro musical deve ser analisado à parte quanto às relações multimidiáticas, pois envolve também a questão visual na criação do sentido. Se imaginarmos a cena proposta, onde o coro reproduz onomatopaicamente o som do disparo de uma arma enquanto aponta as mãos para a plateia como quem segura uma arma e, ao reproduzir o som do disparo sobre a sílaba "ba" da palavra "bala", conforme indicado na partitura, imita, inclusive, o recuo que um disparo real de arma de fogo produziria em quem a segurasse, conjuntamente com o som aspirado sobre a vogal "a" da palavra "bala", como se reproduzisse o som chiado que o calor do disparo produz sobre o cano da arma (Figura 25), podemos dizer que as mídias estão consistentes (consistent) entre si e que, portanto, o modelo que melhor se aplica nesse trecho é, também, o conformance, (conformidade), haja vista que as mídias vêm, juntas, na transferência de seus atributos, recriar a cena de um disparo de arma de fogo. 


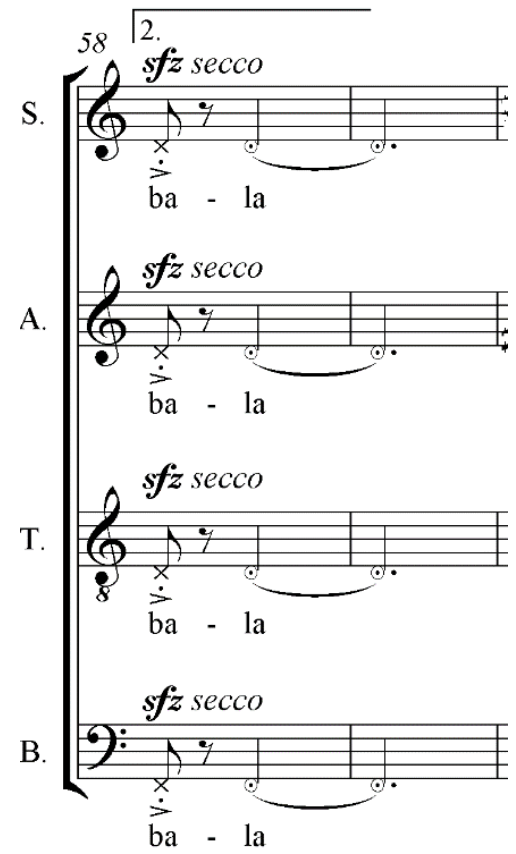

Figura 25. Trecho onde o coro realiza o teatro musical que remete ao disparo de uma arma de fogo. 


\section{CONSIDERAÇÕES FINAIS}

A partir do olhar sobre a vida e a obra de Gilberto Mendes no momento da criação das obras analisadas foi possível, em conjunto com as teorias analíticas multimidiáticas que embasaram nossa análise, traçar um perfil poético do repertório coral à capela que usa Poesia Concreta criado pelo compositor.

O envolvimento de Mendes com o movimento da Poesia Concreta, sobretudo os poetas Décio Pignatari, Haroldo de Campos e Augusto de Campos (que segundo Paulo Franchetti, são a síntese e o início do movimento concretista em poesia no Brasil), e a formulação do Manifesto Música Nova, em total confluência com o próprio Manifesto da Poesia Concreta, não deixam dúvida em relação ao alinhamento do compositor não só com as questões poéticas almejadas pelo movimento concretista pós década de 1950, mas também com a visão política que era compartilhada pelos integrantes de ambos os movimentos, tanto o literário quanto o musical.

$\mathrm{O}$ estabelecimento dos paradigmas para as artes literária e musical dentro do movimento concretista, bem como seu alinhamento mais à esquerda, em consonância com o comunismo, tem marcas muito evidentes nas obras corais à capela de Gilberto Mendes, não só pela influência da poesia, como, por exemplo, é o caso de "O anjo esquerdo da história", com poema homônimo de Haroldo de Campos, onde o engajamento político é claro, mas também na incorporação da linguagem midiática, da indústria cultural, próxima ao público, como recomendava aos poetas concretos João Cabral de Mello Neto, e a recriação dessas fórmulas de marketing, sintetizado, em Gilberto Mendes, no antijingle.

A incorporação das estruturas de riff, típicas da canção de origem estadunidense, e muito usada em jingles publicitários, a repetição de gestos melódicos, a facilidade de apreensão da harmonia e das sonoridades, a simplicidade na condução das vozes, a facilidade de execução, o diálogo com o jazz, são as características que nos permitem enxergar, em termos musicais, os pontos precisos em que Gilberto Mendes dialoga com a indústria cultural, indo ao encontro dos pastiches, das glosas, dos jogos de efeito, da ironia com o qual o movimento da Poesia Concreta, sobretudo o grupo Noigandres, lidava com a rapidez do consumo, mas não para fazer uma obra que fosse facilmente consumida, mas para criar uma obra engajada, que despertasse, através de uma singularidade incorporada aos elementos característicos dessa indústria, como o apelo 
ao consumo, ao imediatismo, ao descartável, ao curto, pudesse criar em quem lesse e, no caso da música coral de Gilberto Mendes, mais especificamente, no caso das obras multimidiáticas aqui analisadas que se valem da relação entre poesia e música, ouvisse tais obras, um senso de estranhamento em relação àquilo que estivesse sendo lido/ouvido, e suscitasse no público, assim, a reflexão, a crítica, a percepção de uma realidade, indo muito além da simples apreciação da obra.

Gilberto Mendes, à época da criação do repertório aqui analisado, talvez não dispusesse de literatura específica que tratasse das relações multimidiáticas criadas quando uma obra contempla em si mesma mais de uma mídia (música, literatura, etc.) ${ }^{84}$, entretanto ficam claras a sua sensibilidade e preocupação com o material literário de que o compositor dispunha, a relação texto-música se mostra rica em termos de interação das mídias, das possibilidades das relações estabelecidas, na criação de metáforas, conformação, complementação e contestação entre as mesmas, produzindo novos significados, percepções e expressividade diferentes daquelas que ambas, texto e música, poderiam ter separadamente.

Logo, além de evidenciarmos as potências multimidiáticas atingidas pelos processos de criação musical de Gilberto Mendes para o repertório analisado neste trabalho, esperamos que a edição das obras aqui analisadas, bem como as análises possam contribuir para a perpetuação desse repertório e que tais obras possam, assim, se consolidar como parte da tradição do repertório coral de música brasileira, não só por sua importância estética e artística, ou por seu caráter e espírito inovadores na criação e utilização dos conceitos multimidiáticos, mas, também, por sua importância musical, pois se trata de obras corais acessíveis, capazes de ajudar a construir e constituir o repertório coral brasileiro, contribuindo, assim, para o enriquecimento e acesso à música contemporânea no Brasil, e especialmente a música coral.

\footnotetext{
${ }^{84}$ Segundo Cook (2004, p. 107), o princípio das teorias multimidiáticas remete à "República" de Platão (428 - 348 a.C.), mas apenas como ensaios, sem aprofundamentos técnicos e teóricos específicos, ou análises de obras multimidiáticas.
} 


\section{REFERÊNCIAS}

ALMADA, Carlos. Arranjo. $1^{\text {a }}$ Edição. Campinas: Editora da Unicamp, 381 p., 2000.

BENJAMIN, Walter. A obra de arte na era de sua reprodutibilidade técnica. In: Magia e técnica, arte e política - Ensaios sobre literatura e história da cultura. Rio de Janeiro: Editora Brasiliense. $3^{\text {a }}$ Edição, pp.165-96, 1987.

BONVICINO, Régis. O sentido do sol de Maikóvski. In: SIBILA - Poesia e Crítica Literária. [S.1.], Ano 14, 2012. Disponível em: <http://sibila.com.br/critica/o-sentido-dosol-de-maiakovski/5322>. Acesso em 11 mai. 2014.

CAMPOS, Augusto de; CAMPOS, Haroldo de; PIGNATARI, Décio. Teoria da Poesia Concreta. $4^{\text {a }}$ Edição. Cotia: Ateliê Editorial, 289 p., 2006.

CAPLIN, William E. Classical form: a theory of formal functions for the instrumental music of Haydn, Mozart, and Beethoven. New York: Oxford University Press, 320 p., 1998.

CARVALHO, Any Raquel. Contraponto Modal - Manual prático. $1^{a}$ Edição. Porto Alegre: Editora Sagra Luzzatto: Novak Multimedia, 131 p., 2000.

COOK, Nicholas. Analysing Musical Multimedia. New York: Oxford University Press, 304 p., 2004.

COSTA, Elisa Gomes da; SIMÕES, Elsa. A tradução na poesia concreta: algumas reflexões. Repositório Científico de Acesso Aberto de Portugal. Universidade Fernando Pessoa. Porto: 2008. Disponível em: < http://hdl.handle.net/10284/901>. Acesso em 3 jun. 2013.

DOURADO, Henrique Autran. Dicionário de termos e expressões da música. São Paulo: Editora 34. $2^{\text {a }}$ Edição, 384 p., 2004. 
ERBER, Pedro. The Word as Object - Concrete Poetry, Ideogram, and the Materialization of Language. Luzo-Brazilian Review, V. 49, N. 2, p. 72-101, 2012. Disponível em: <>. Acesso em 2 abr. 2013.

FAUSTO, Boris. História do Brasil. São Paulo: Editora da Universidade de São Paulo, $14^{\mathrm{a}}$ ed., 688 p., 2012.

FRANCHETTI, Paulo. Alguns aspectos da teoria da poesia concreta. $4^{\text {a }}$ Edição. Campinas: Editora da Unicamp, 197 p., 2012.

GRIFFITHS, Paul. A músca moderna. 1ª Edição. Rio de Janeiro: Jorge Zahar Editor Ltda., Tradução: Clóvis Marques, 206 p., 1987.

KATER, Carlos. Música Viva e H. J. Koelreutter - movimentos em direção à modernidade. São Paulo: Musa Editora, 371 p., 2001.

MENDES, Gilberto. Uma Odisseia Musical: Dos Mares do Sul Expressionista à Elegância Pop/Art Déco. São Paulo: Edusp - Editora Giordiano, 336 p., 1994.

Viver sua música: com Stravinsky em meus ouvidos, rumo à avenida. $1^{\mathrm{a}}$ Edição. São Paulo: EDUSP, 374 p., 2008.

O ANJO ESQUERDO DA HISTÓRIA. Santos, 1997. 1 partitura [fac-simile do manuscrito, 13 p.]. Coral.

SOL DE MAIKÓVSKI. Santos, 1995. 1 partitura [fac-simile do manuscrito, 2 p.]. Coral.

TEMPO TEMPO. Santos, 1991. 1 partitura [fac-simile do manuscrito, 2 p.]. Coral.

TVGRAMA I. Santos, 1995. 1 partitura [fac-simile do manuscrito, 3 p.]. Coral. 
UMA VEZ UMA VALA. [S.1.], 1993. 1 partitura [fac-simile do manuscrito, 8 p.]. Coral.

OUVRARD, Jean Pierre. A música no século XVI: Europa do Norte, França, Itália, Espanha. In: História da Música Ocidental. Rio de Janeiro: Nova Fronteira. 1256 p. 1997.

PERSICHETTI, Vincent. Twentieth Century Harmony: Creative aspects and practice. $2^{\text {a }}$ Edição. Londres: Faber and Faber Limited, 287 p., 1978.

PRICE, Rachel. Object, Non-Object, Transobject, Relational Object: From "Poesia Concreta” to “A Nova Objetividade”. Revista de Letras, São Paulo, V. 47, N. 1, p. 3150, 2007. Disponível em: <http://www.jstor.org/stable/27666821>. Acesso em 28 mai. 2013.

PAREYSON, Luigi. Os problemas da estética. São Paulo: Martins Fontes. $3^{\text {a }}$ Edição, 246 p., 1997.

SCHOENBER, Arnold. Fundamentals of Musical Composition. Londres: Faber and Faber, 216 p., 1967.

SOUZA, Carla Delgado de. Gilberto Mendos: Entre a vida e a arte. $1^{\text {a }}$ Edição. Campinas: Editora da Unicamp, 264 p., 2013.

SMITH, Timothy A. The Barroque Ideal. Página da Internet. [S.1.], 1996. Disponível em: <http://jan.ucc.nau.edu/ tas3/baroqueideal.html>. Acesso em 16 jun. 2014.

TRAGTENBERG, Livio. Contraponto: uma arte de compor. $1^{\text {a }}$ Edição. São Paulo: Editora da Universidade de São Paulo, 267 p., 1994.

VIGNAL, Marc. A música luterana no século XVI. In: História da Música Ocidental. Rio de Janeiro: Nova Fronteira. 1256 p. 1997. 


\section{ANEXO A - PARTITURAS EDITADAS}

Fizemos essas edições a partir dos fac-similes, disponibilizados a nós pelo próprio compositor através do Serviço de Edição e Difusão de Partituras do Núcleo de Apoio à Pesquisa em Ciências da Performance (NAP-CIPEM) da Faculdade de Filosofia, Ciências e Letras de Ribeirão Preto da Universidade de São Paulo (FFCLRP/USP). Sendo assim, mantivemos articulações e sinais agógicos (dinâmicas, crescendi, andamentos, etc.) escritas pelo próprio compositor, sem qualquer interferência nossa, sendo a única exceção a reformulação de alguns trechos do texto de execução da obra "TEMPO TEMPO", onde algumas ambiguidades existentes no original do fac-simile foram modificadas a fim de melhorar a compreensão por parte do intérprete, minimizando, assim, possíveis enganos ${ }^{85}$.

\section{TEMPO TEMPO}

Fragmento de Eclesiastes segundo Haroldo de Campos

Música de Gilberto Mendes

\section{SEQUÊNCIA DE EXECUÇÃO E INSTRUÇÕES}

A - Introdução, sem partitura. Todas as vozes, no ritmo do Quadro B, falam durante alguns segundos (mínimo 30) a palavra "tempo", sem som, somente o movimento dos lábios; depois em som expirado, começando por "ppp" e terminando em "fff".

B - Vozes solistas, conforme Quadro B (afinadas discretamente durante o Quadro A), que deverá ser repetido no mínimo 4 vezes.

C - Este Quadro é formado por 2 Compassos. Solistas cantam conforme a partitura, continuando o Quadro pela repetição desses 2 Compassos no mínimo 6 vezes; depois do quê o regente vai afinando o acorde, pelo resto da massa coral, do Quadro

\footnotetext{
${ }^{85}$ Nas instruções para o Quadro B, a palavra "partitura" foi substituída por "Quadro"; as instruções para o Quadro G foram dissociadas das instruções para o Quadro F; a palavra "quadro" passou a ser grafada com a primeira letra em caixa alta; a abreviação "N.B." foi trocada por "Nota"; e a expressão "quaisquer cantores" em "N.B." foi trocada para "qualquer um dos cantores".
} 
seguinte (em notas brancas, Quadro D). Esse acorde vai crescendo, enquanto a leitura do texto, que continua, vai diminuindo, desaparecendo pela dissolução de cada voz solista no acorde que vai dominar o Quadro até chegar a "quasi f", dando início ao Quadro seguinte, pela interrupção, desaparecimento da leitura do texto.

$\mathrm{D}$ - O acorde (em notas brancas) será feito por todo o coral. Cada cantor demora o maior tempo possível na sílaba "tem", passando alternada e gradativamente dos fonemas /te/ para $/ \mathrm{m} /$, terminando em /po/, sem acentuar nada; respira o mais breve possível e retoma o mesmo processo até o final do Quadro. Enquanto os solistas, nas alturas, cada um, das notas pretas, dizem o texto (vide texto abaixo) na sequência em que está escrito a 2, a 3 até 8 vozes, conforme indicação do regente, cada indicação valendo para dizer uma frase (as frases estão divididas pelo sinal §). Depois de todo lido, em sua sequência como está escrito no texto, cada solista, quando indicado pelo regente, dirá a frase que desejar. Poderá haver sobreposição de frases diferentes quando o regente indicar mais de um solista ao mesmo tempo. Finalizando este Quadro, o regente deve estreitar as entradas, sobrepondo muitas indicações de entradas, que agora deverão soar como uma discussão, em toma mais falado do que em altura fixa. Este Quadro D é o centro da peça e deve durar bastante.

E - Depois de uma pausa súbita, interrompendo a "discussão" e o acorde, todo o coral cantará os acordes microtonais conforme a partitura, em sentido contrário (Soprano e Tenor contra Contralto e Baixo), no andamento do quadro B. Em alguns momentos, o regente fixa o coral, ora em "tem", ora em "po", prolongando o acorde microtonal resultante, agora fixo por alguns segundos, e indicando depois as vozes solistas para dizerem, a cada indicação, uma frase qualquer do texto do Quadro C, escolhida pelo solista, na altura em que vinha cantando, vale dizer, na altura atacada ao acaso quando deu entrada no acorde microtonal. Resultará daí, quando o regente indicar 2 solistas ao mesmo tempo, um intervalo microtonal; quando o regente indicar mais de 2 solistas, resultará num acorde microtonal entre os solistas (intervalos e acorde que serão ouvidos em meio ao acorde microtonal fixo, que continua soando, cantado pela massa coral). Neste momento do Quadro, o regente silenciará, por vezes, a massa coral, deixando que sejam ouvidas somente as vozes solistas, em seus intervalos ou acordes microtonais. Num destes momentos, o regente finaliza o Quadro E.

F - Depois de uma pausa longa, os solistas principais (dos Quadros B e C) começam a executar o Quadro F (discretamente já vinham afinando as notas), e o resto 
da massa coral vai entrando aos poucos nessa execução do Quadro F, que deve ser repetido várias vezes.

$\mathrm{G}-$ É executado, sem interrupção, em seguida do Quadro F.

Nota: O som do diapasão (para afinação discreta) deve ser ouvido. Solistas do Quadro E pode ser qualquer um dos cantores.

III

1. Para tudo $\S$ seu momento $\S \quad \S \S$

E tempo para todo vento $\S \quad$ sob o céu

2. Tempo de nascer $\S$

Tempo de plantar

e tempo de morrer

$\S \S \S$

3. Tempo de matar $\S$

$\S \S$

Tempo de destruir $\S$

e tempo $\S \quad$ de arrancar a planta

e tempo de curar $\S \S$

e tempo de construir

4. Tempo de pranto $\S$

tempo de ânsia $\S$

e tempo de riso $\S \S$

e tempo de dança

5. Tempo de atirar pedras

Tempo de abraçar

e tempo $\S$ de retirar pedras $\quad \S \S \S$

6. Tempo de procurar $\S$

e tempo $\S$ de afastar os braços

tempo de reter $\S$

e tempo de perder $\S \S$

e tempo de dissipar

e tempo de coser $\S \S$

7. Tempo de rasgar $\S$

tempo de calar $\S$

e tempo de falar

e tempo de odiar $\S \S$

tempo de guerra $\S$

e tempo de paz 
Música: Gilberto Mendes Poema: Haroldo de Campos, baseado em fragmento do Livro bíblico de Eclasiastes
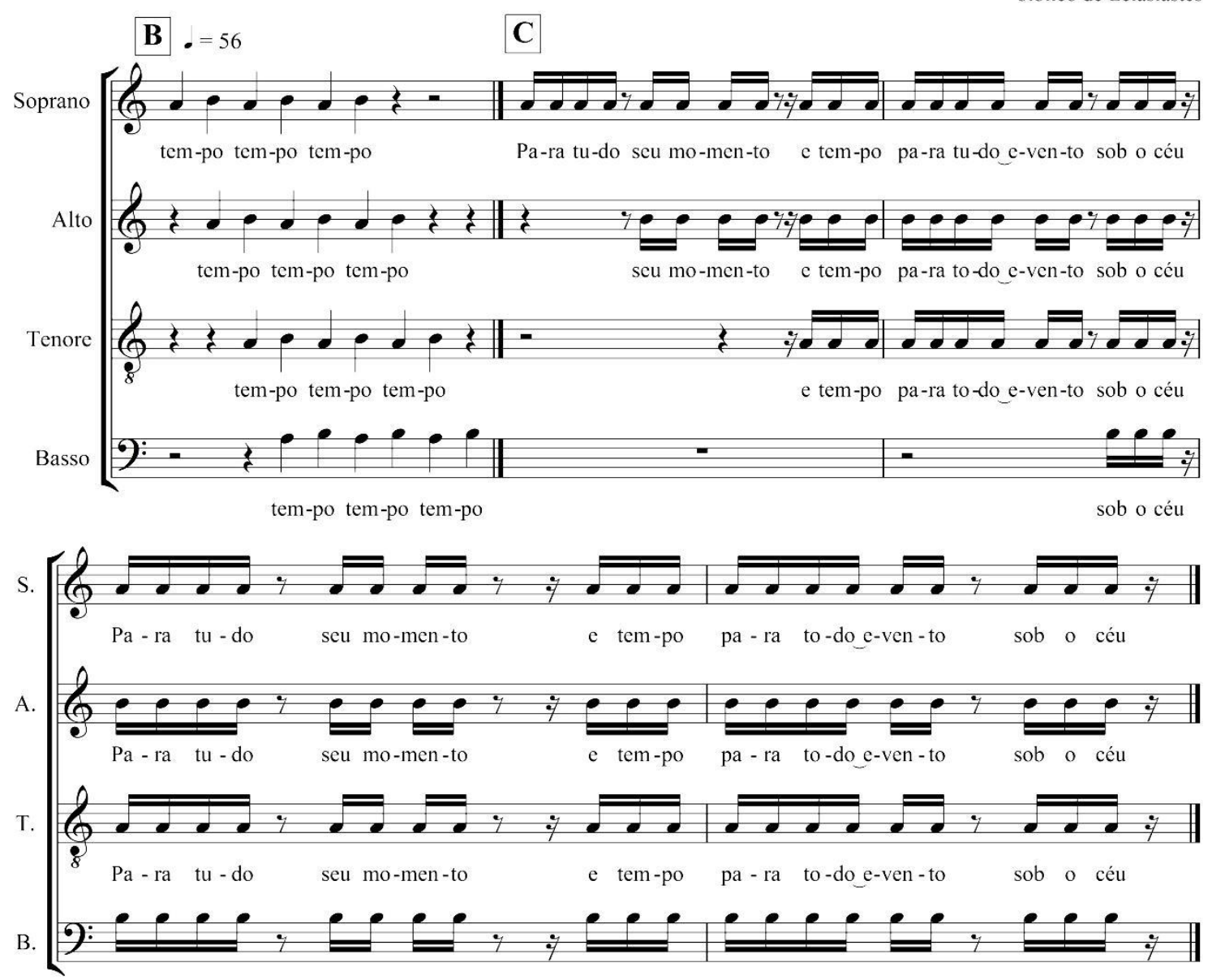
$\mathrm{Pa}$ - ra tu - do seu mo-men -to e tem-po sob o céu

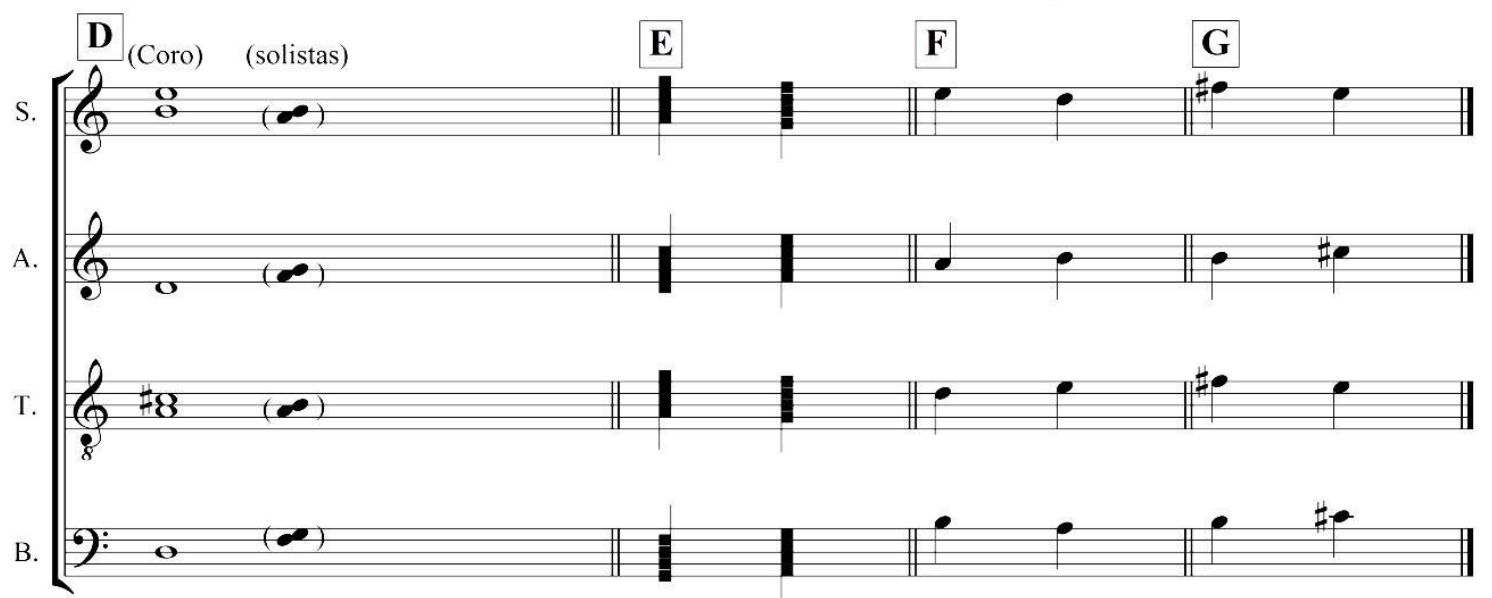




\section{SOL DE MAIAKÓVSKI}

SOL DE MAIKÓVSKI

Música: Gilberto Mendes Poema: Augusto de Campos
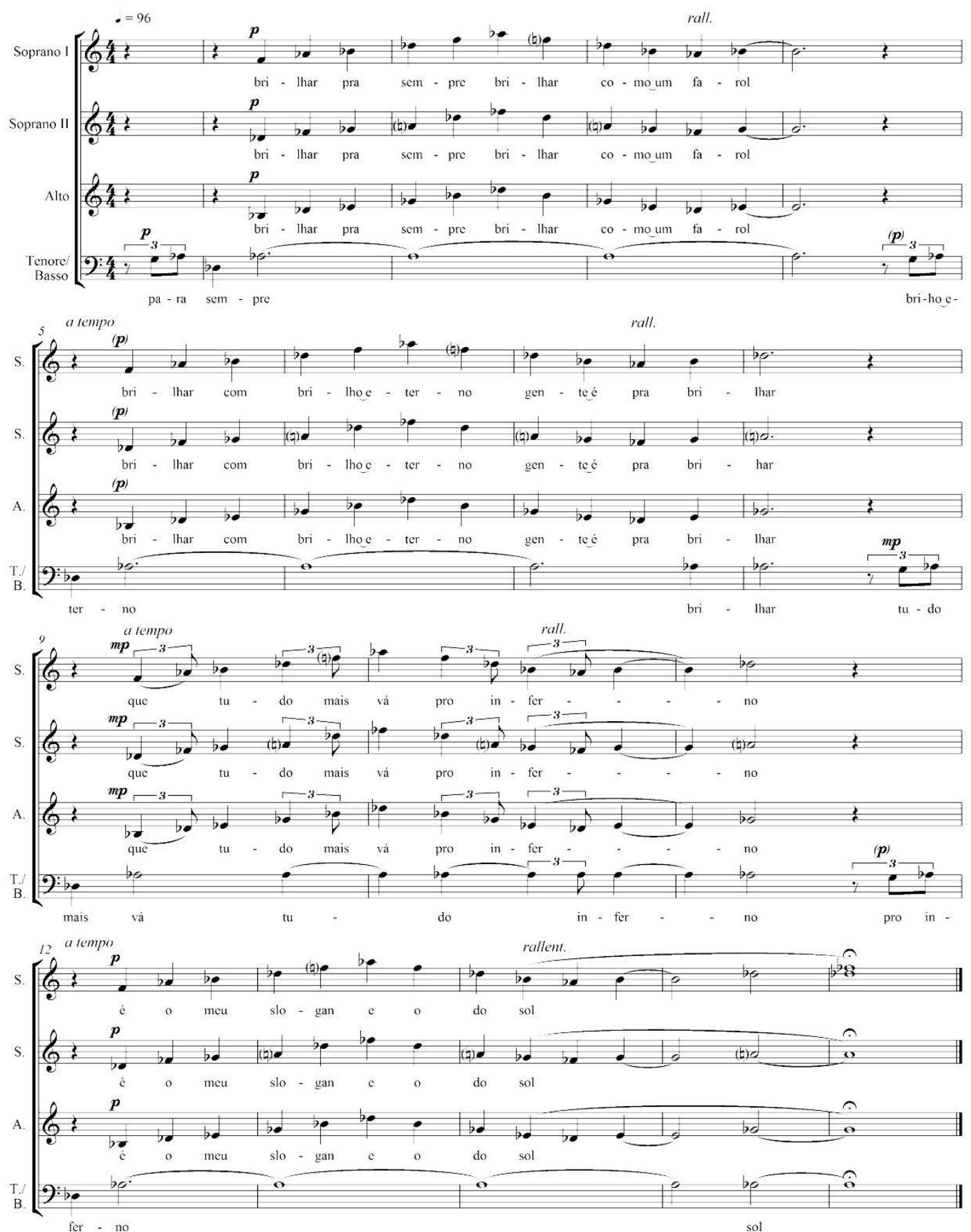


\section{TVGRAMA I}

TVGRAMA I

(TOMBEAU DE MALLARMÉ)

Música: Gilberto Mendes Poema: Augusto de Campos
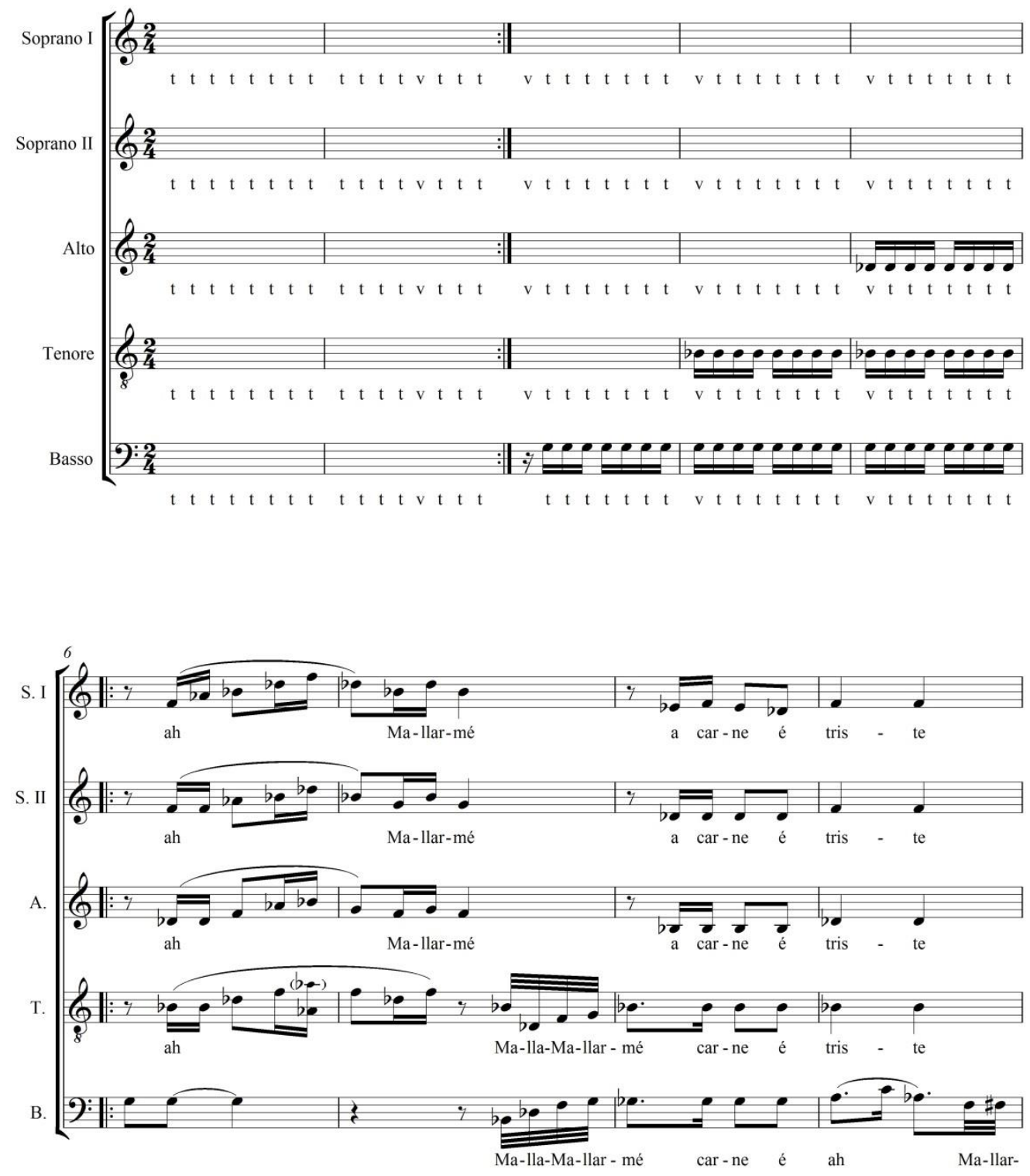

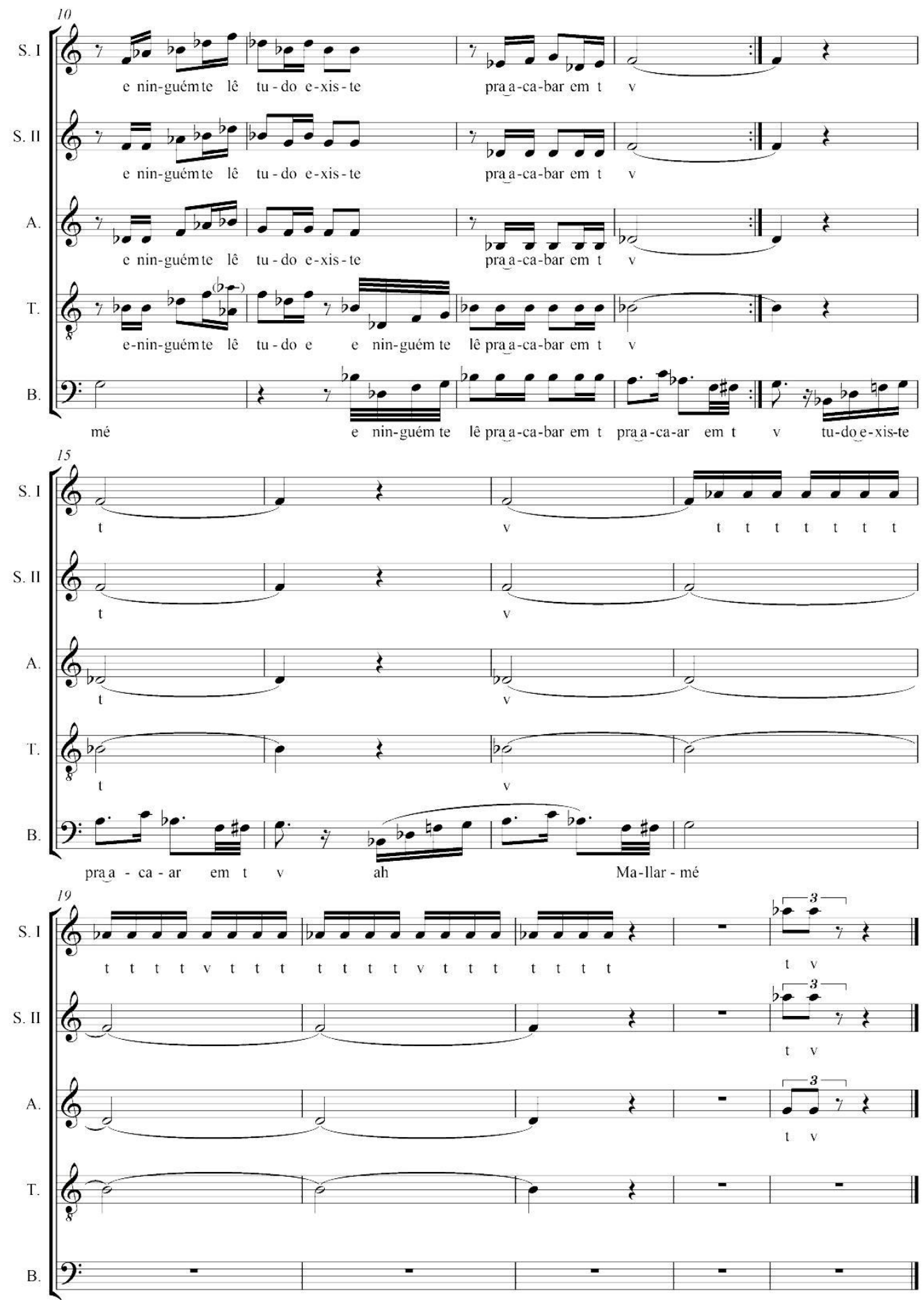

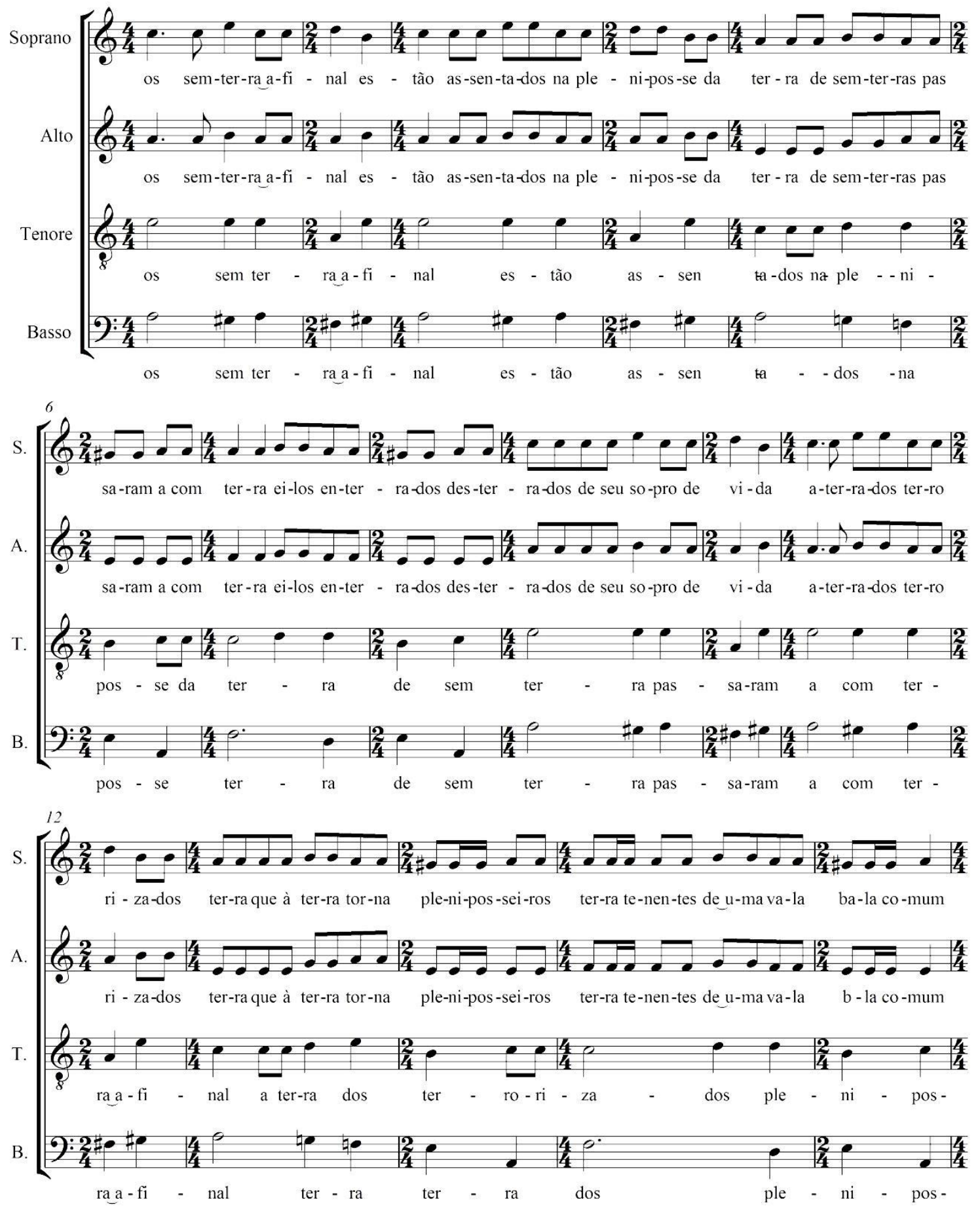

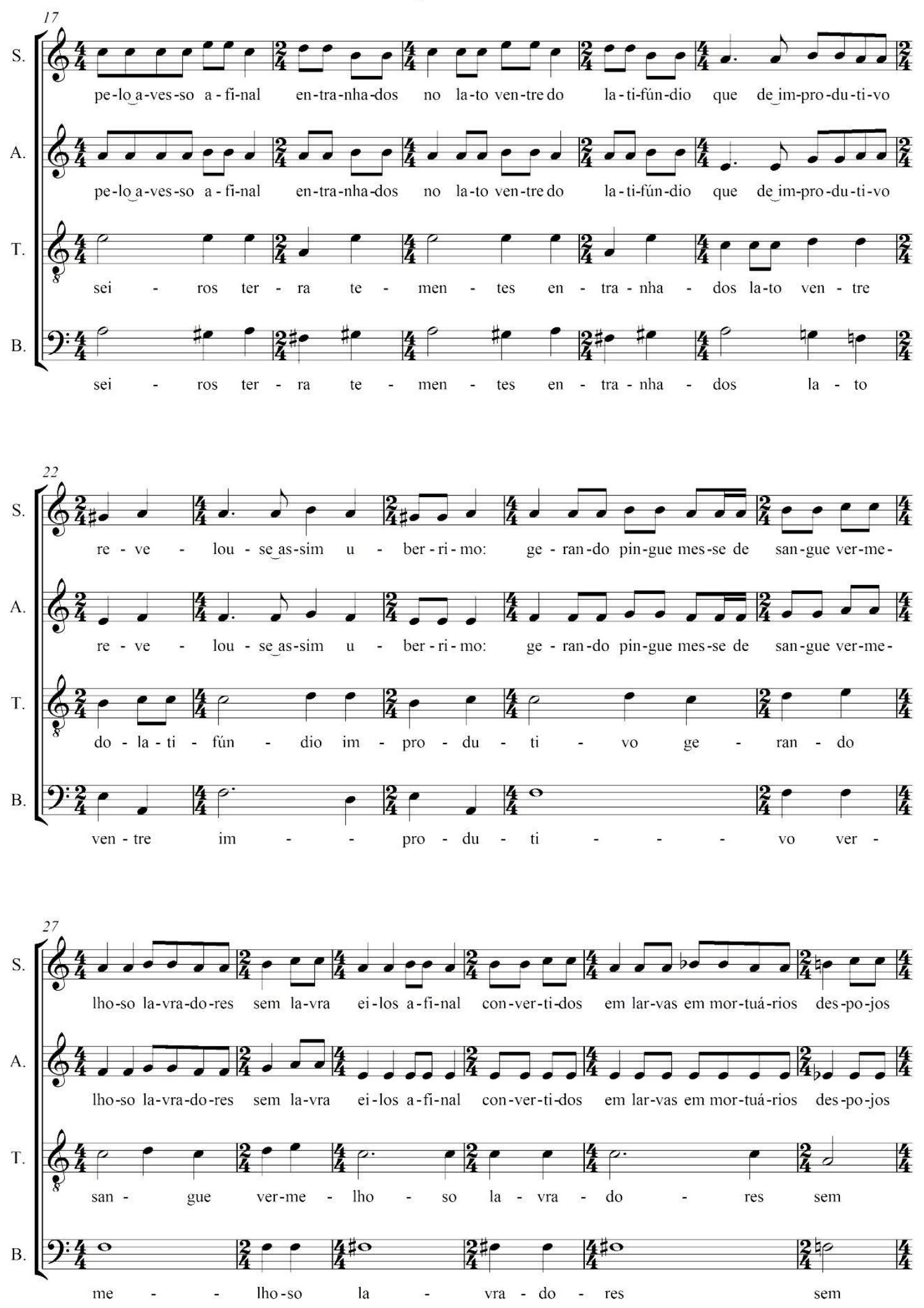

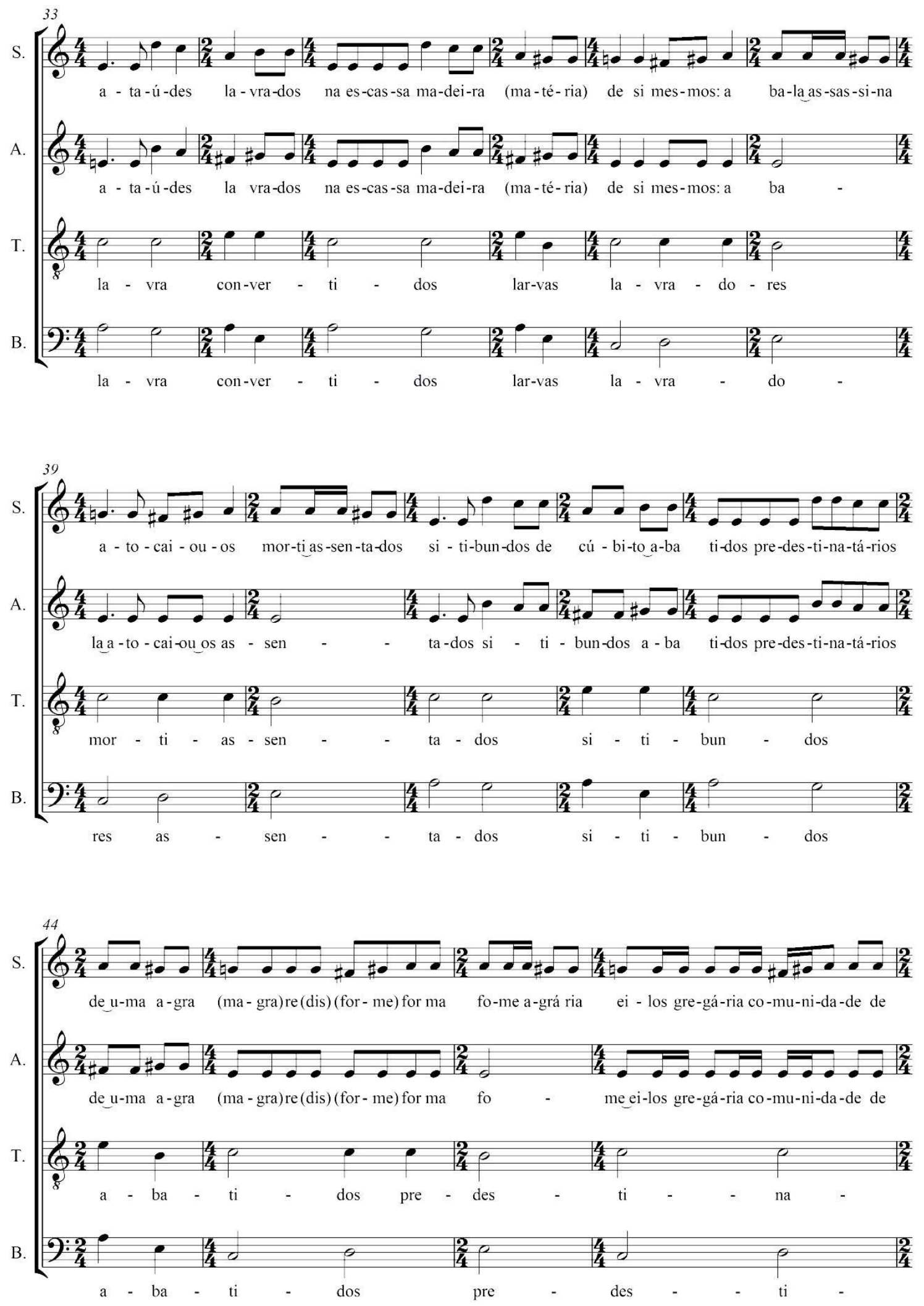

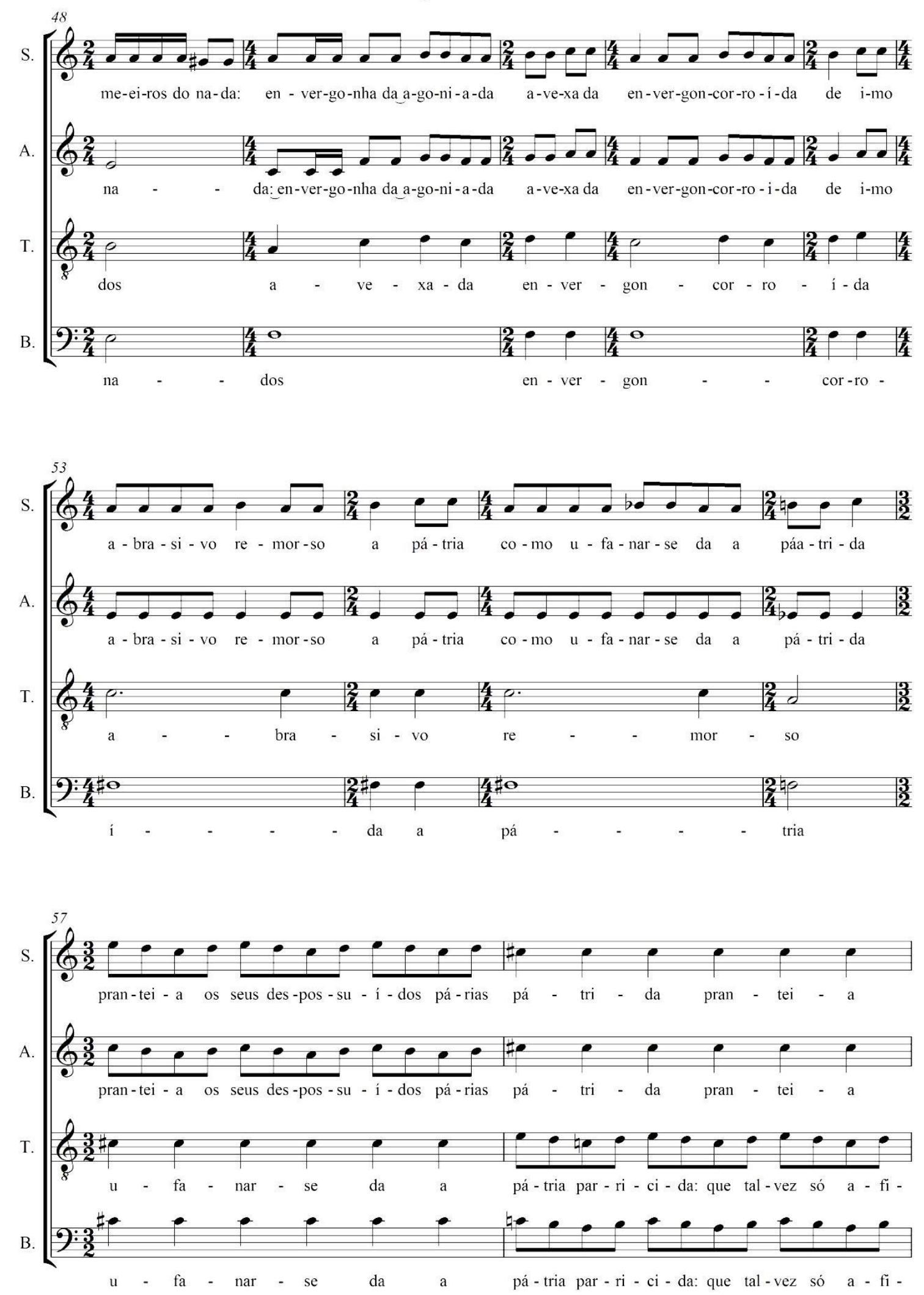

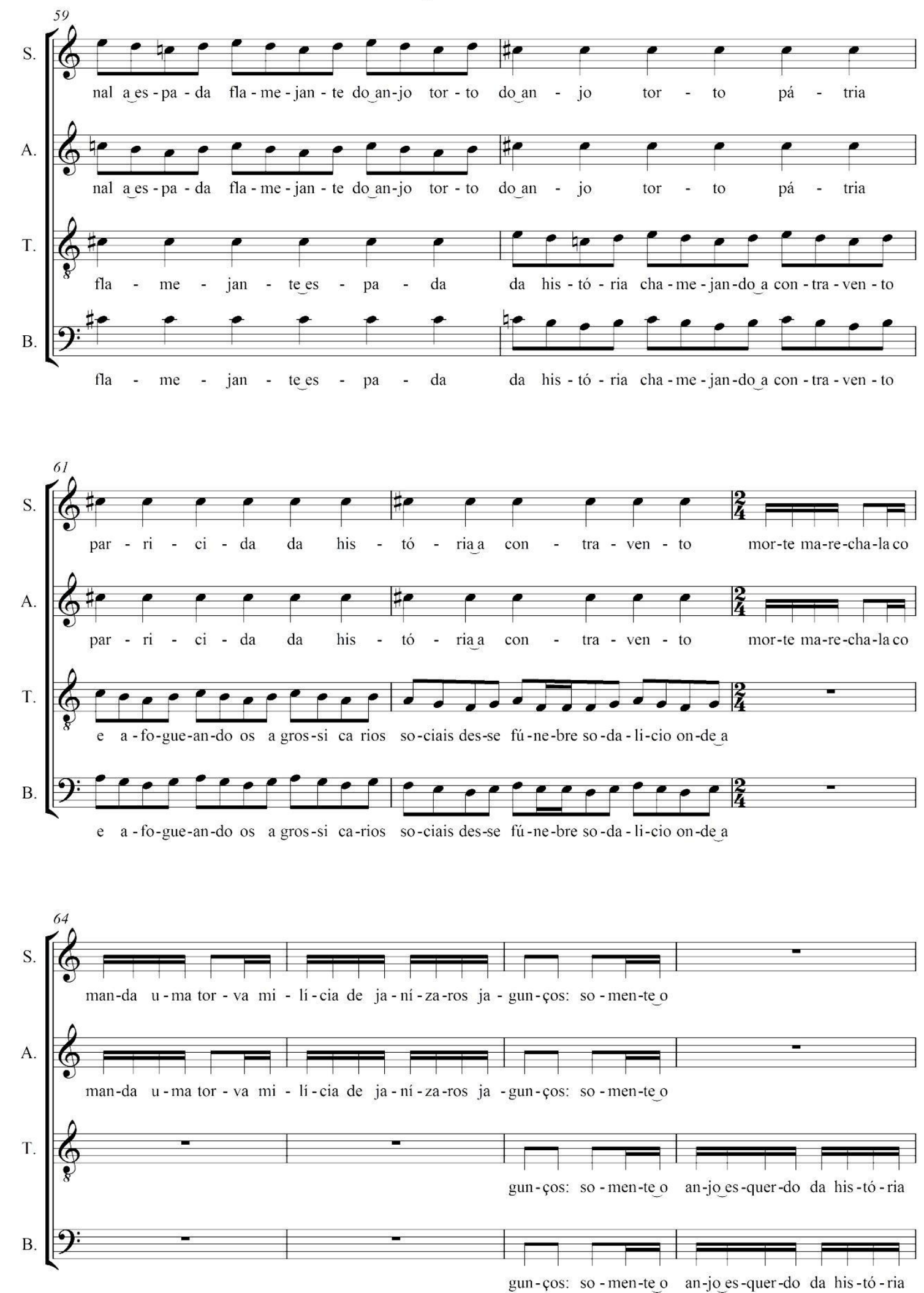


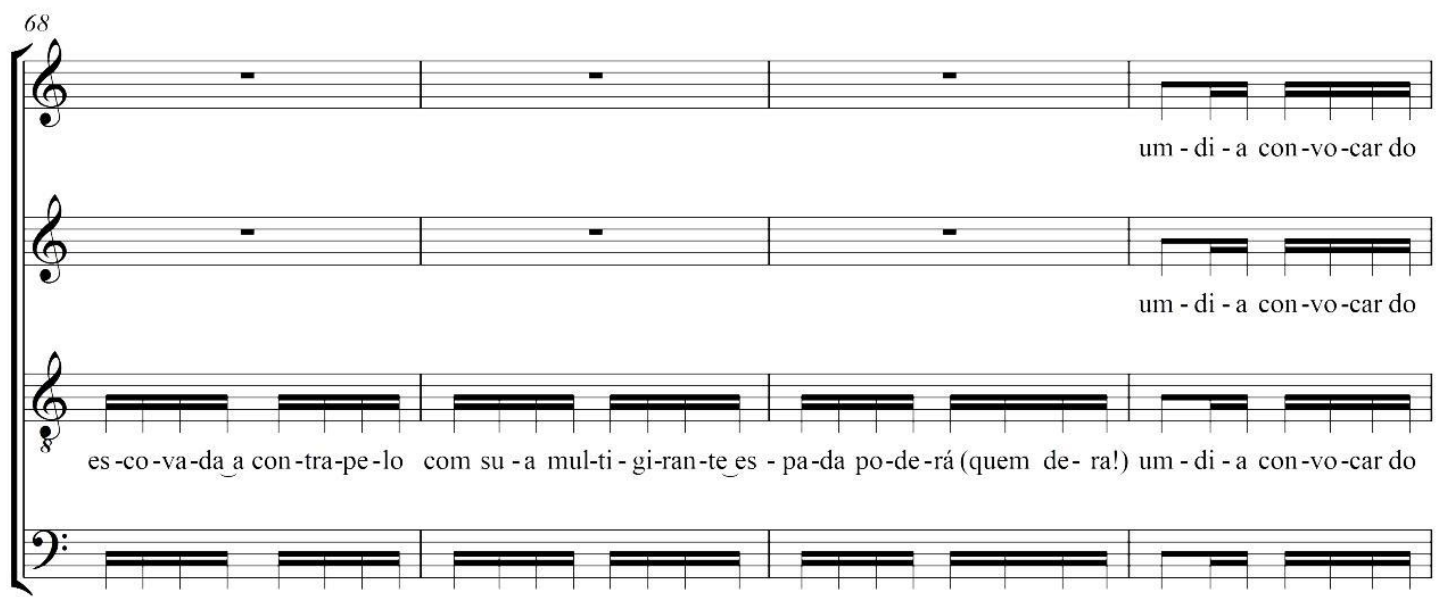

es -co-va-da a con-tra-pe-lo com su - a mul-ti - gi-ran-te es - pa-da po-de-rá (quem de- ra!) um - di - a con-vo-car do

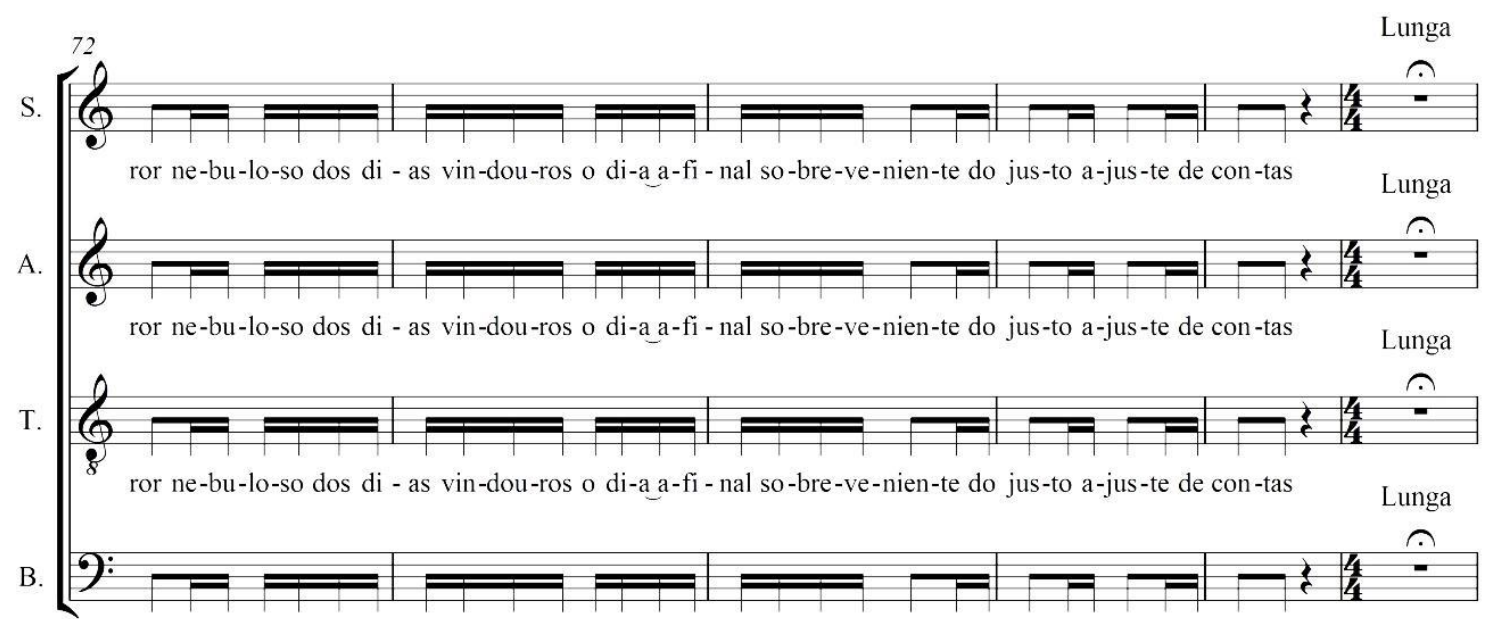

ror ne-bu-lo-so dos di - as vin-dou-ros o di-a a-fi - nal so-bre-ve-nien-te do jus-to a-jus-te de con-tas

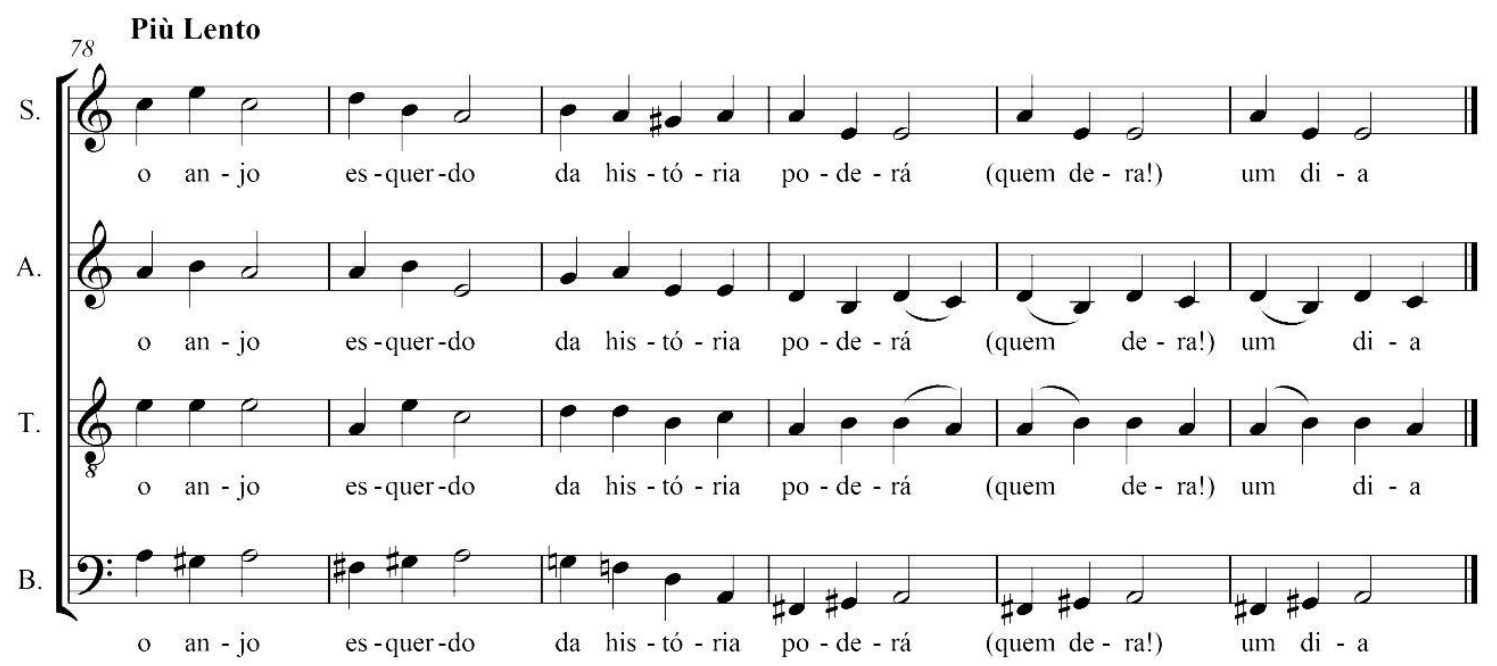




\section{UMA VEZ UMA VALA}

\section{UMA VEZ UMA VALA}

Música: Gilberto Mendes Poema: Augusto de Campos
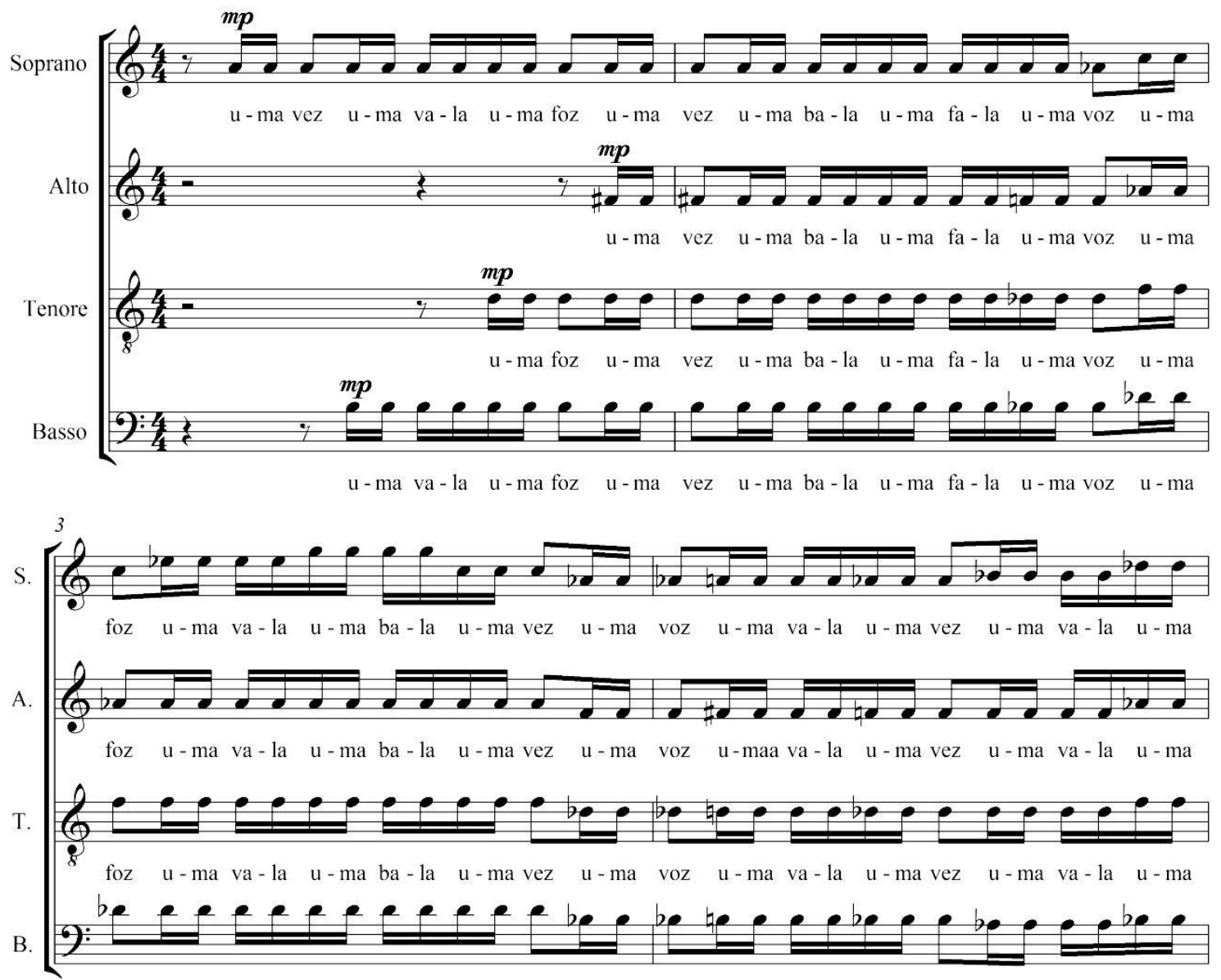

foz u-ma va-la u-ma ba-la u-ma vez u-ma voz u-ma va-la u-ma vez u-ma va-la u-ma

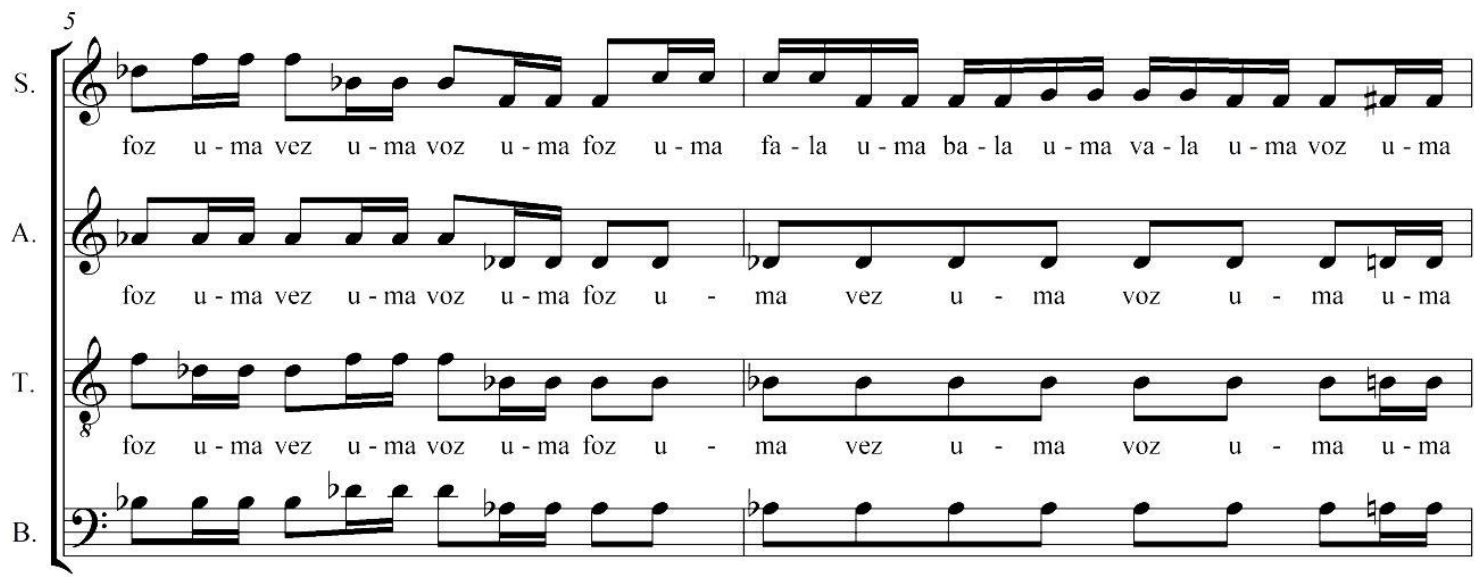

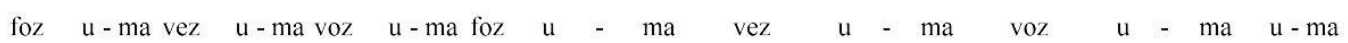



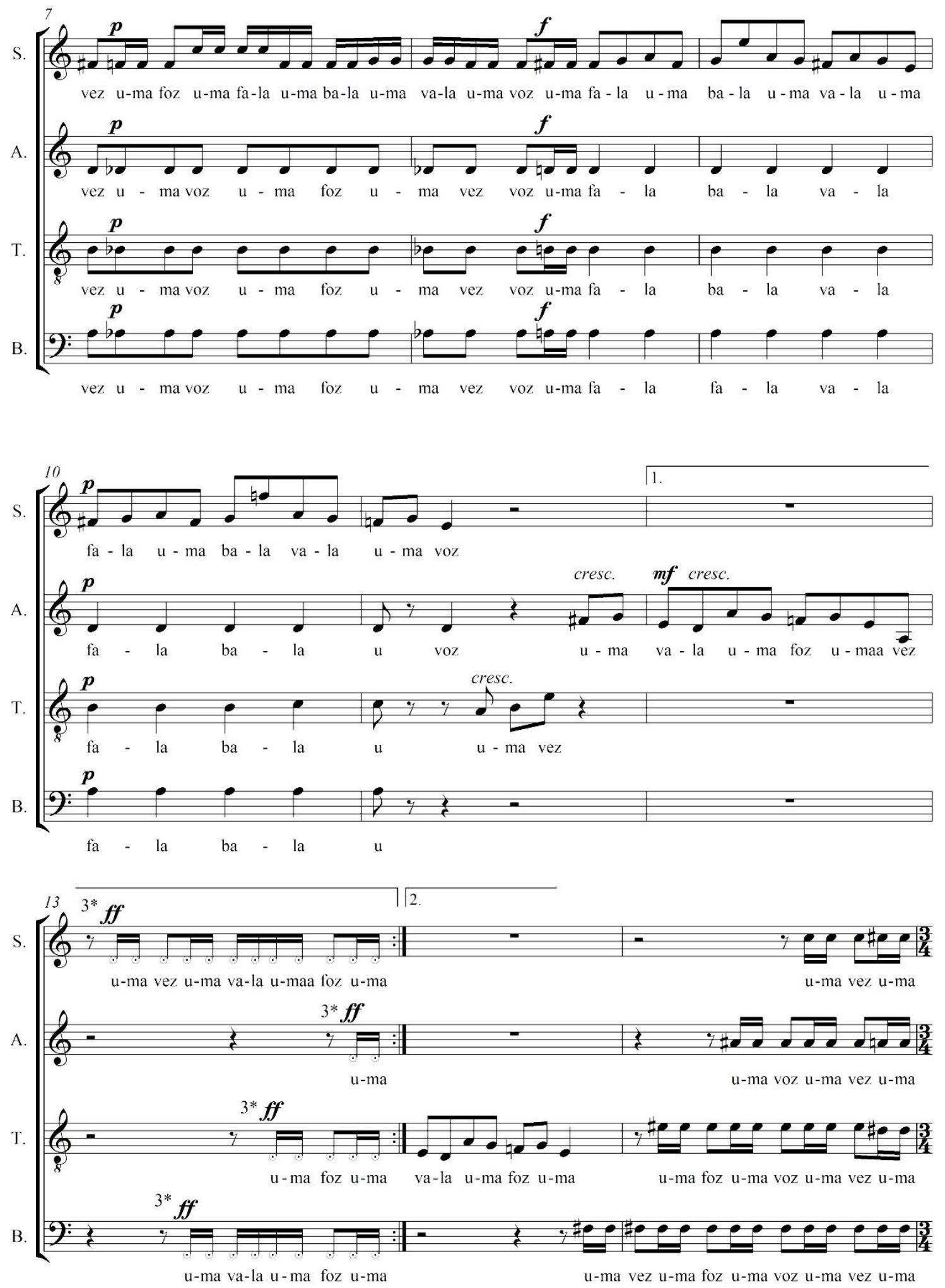

Obs.: significado dos números com asterisco $(*)$ ao final da partitura. 

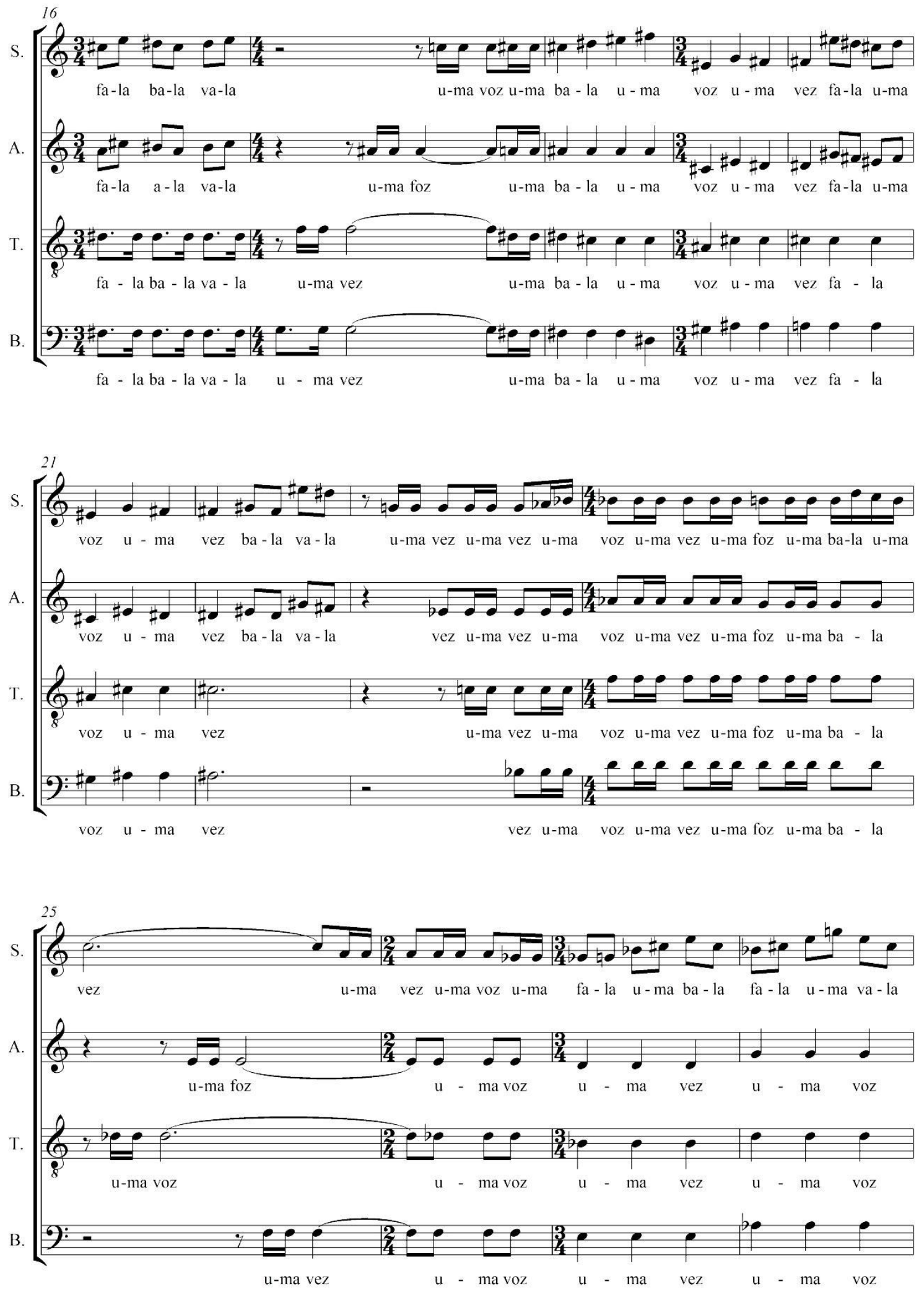

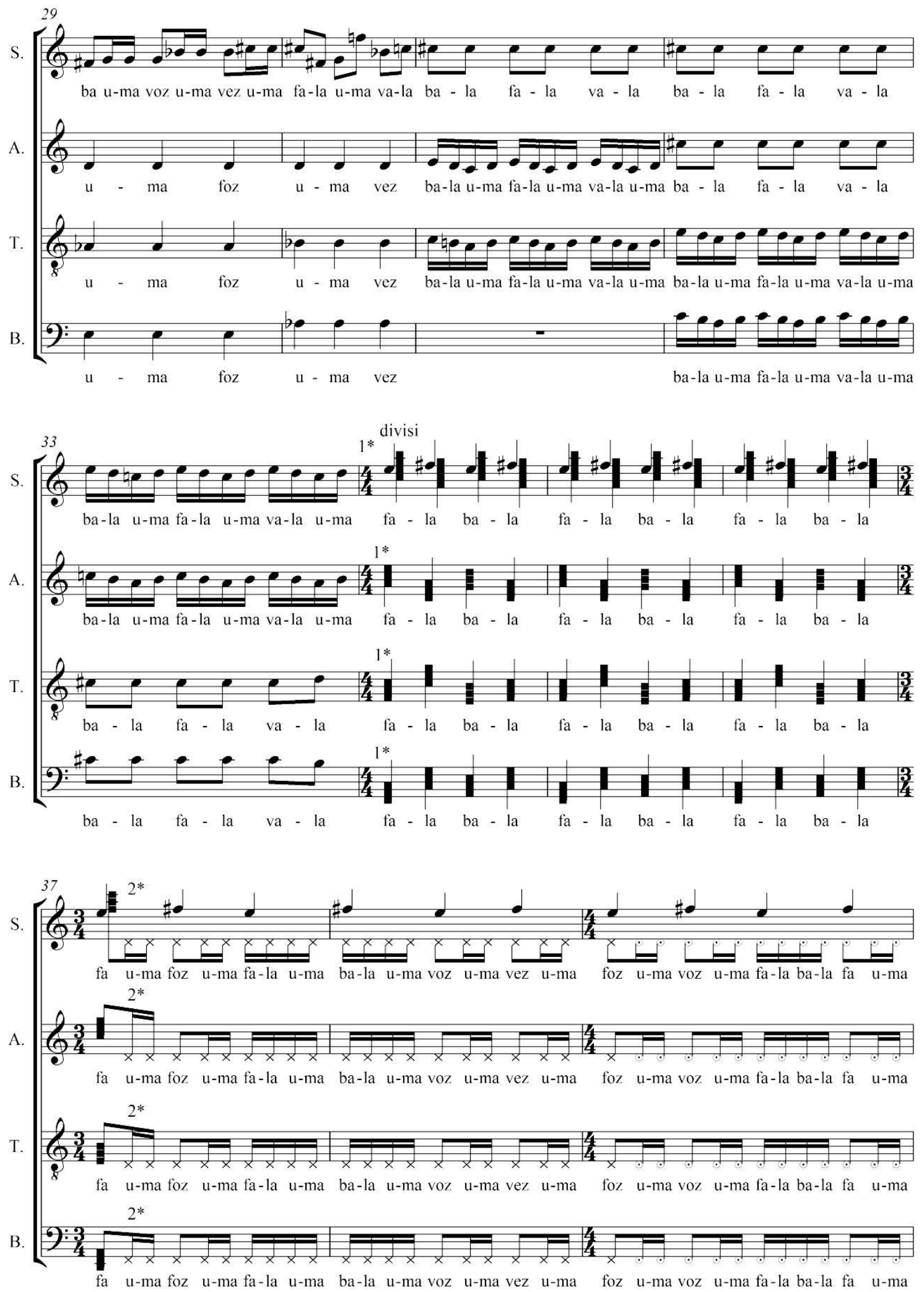

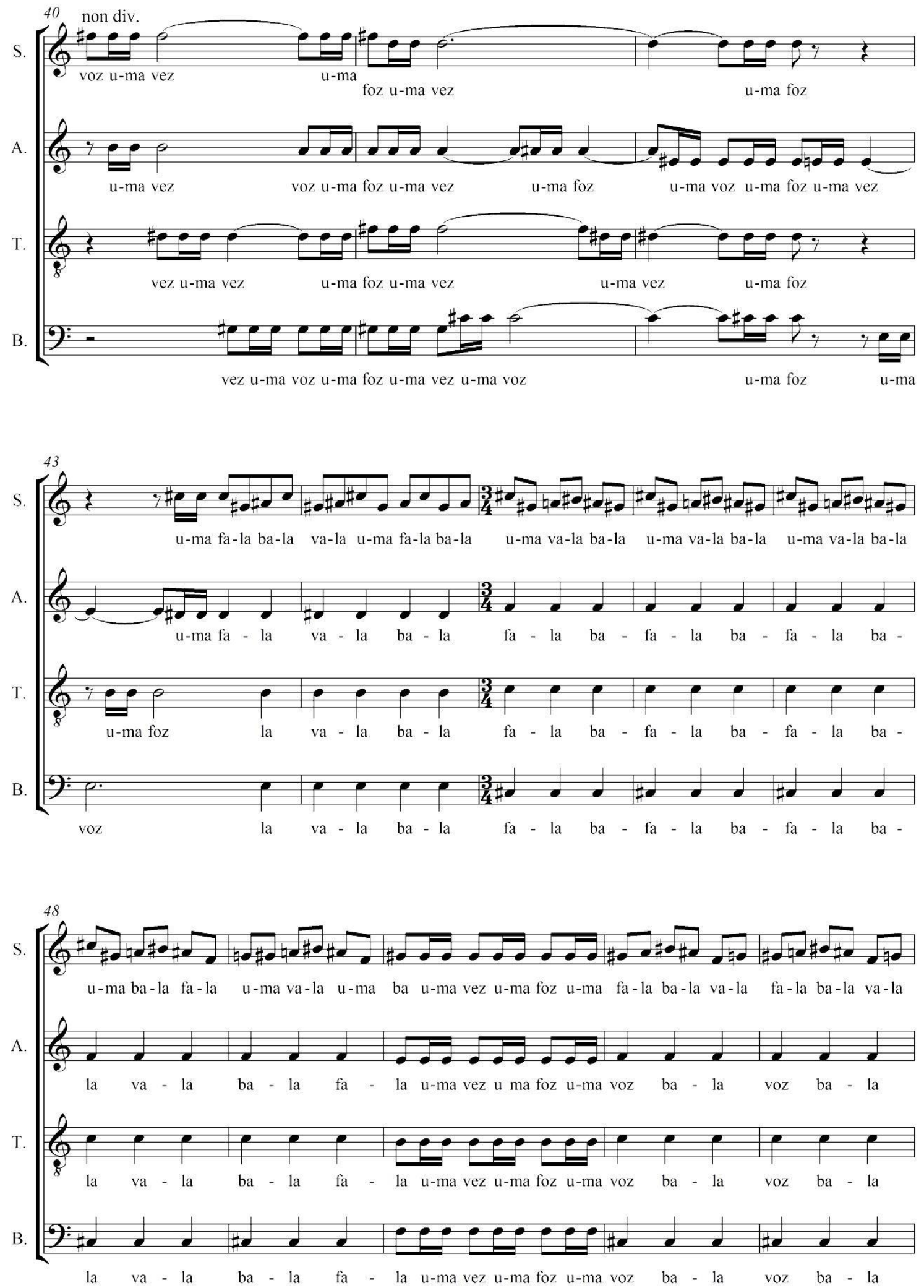

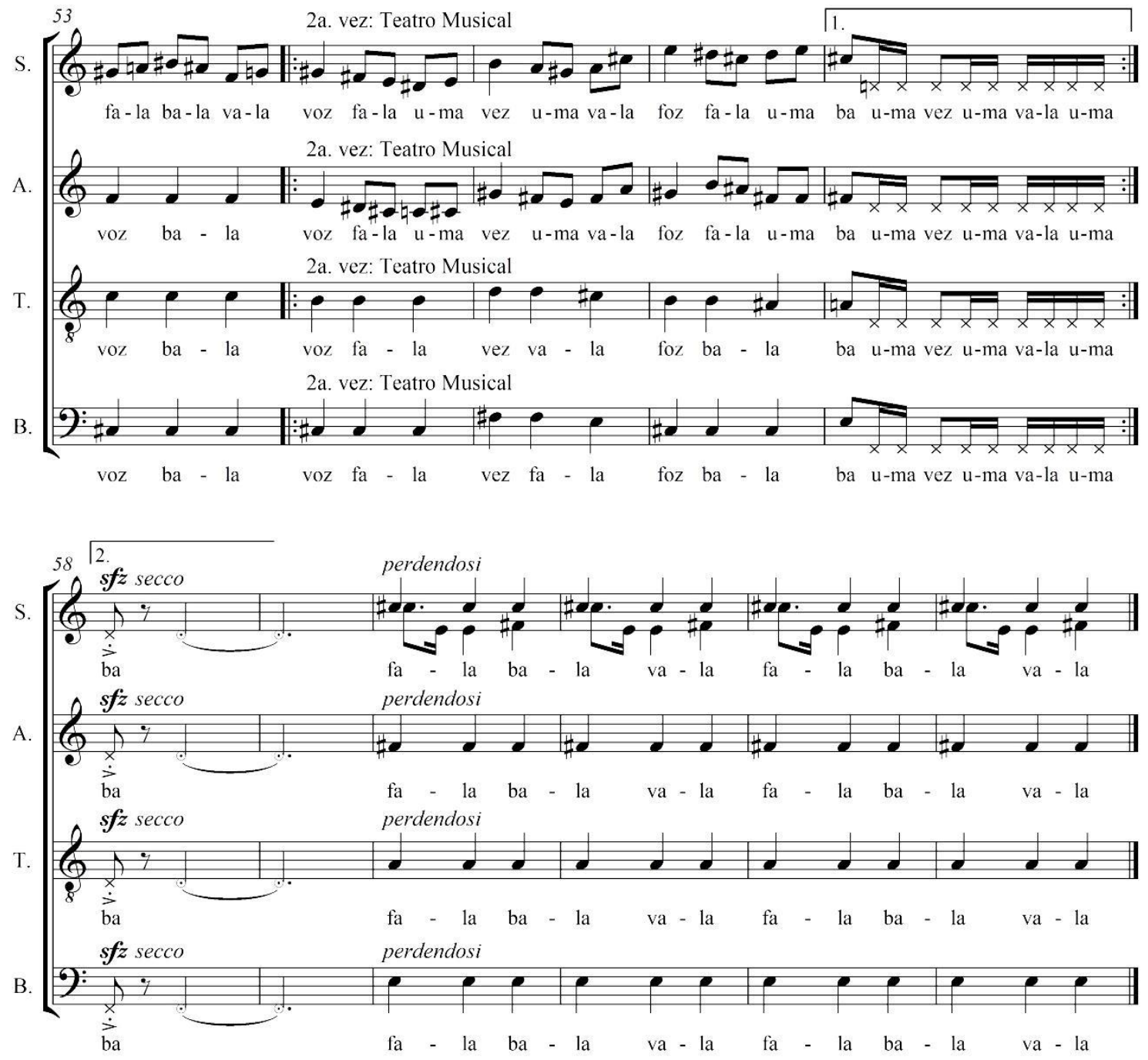

TEATRO MUSICAL: os cantores vão fechando as mãos como que para segurar um revólver e dar o "tiro" final "ba"; e mantêm as mãos imitando o revólver apontado para o público até o fim, depois do "tiro".

Símbolos: $1 *$ chuster microtonal; os:lusters são de vozes femininas e masculinas em movimento contrário; $2^{*}$. som falado; $3^{*}$. som expirado; 